Prepared for the U.S. Department of Energy under Contract DE-AC05-76RL01830

\title{
Investigations into the Nature of Alkaline Soluble, Non-Pertechnetate Technetium
}

BM Rapko

SA Bryan

$S$ Chatterjee

MK Edwards
TG Levitskaia

JM Peterson

RA Peterson

SI Sinkov

November 2013

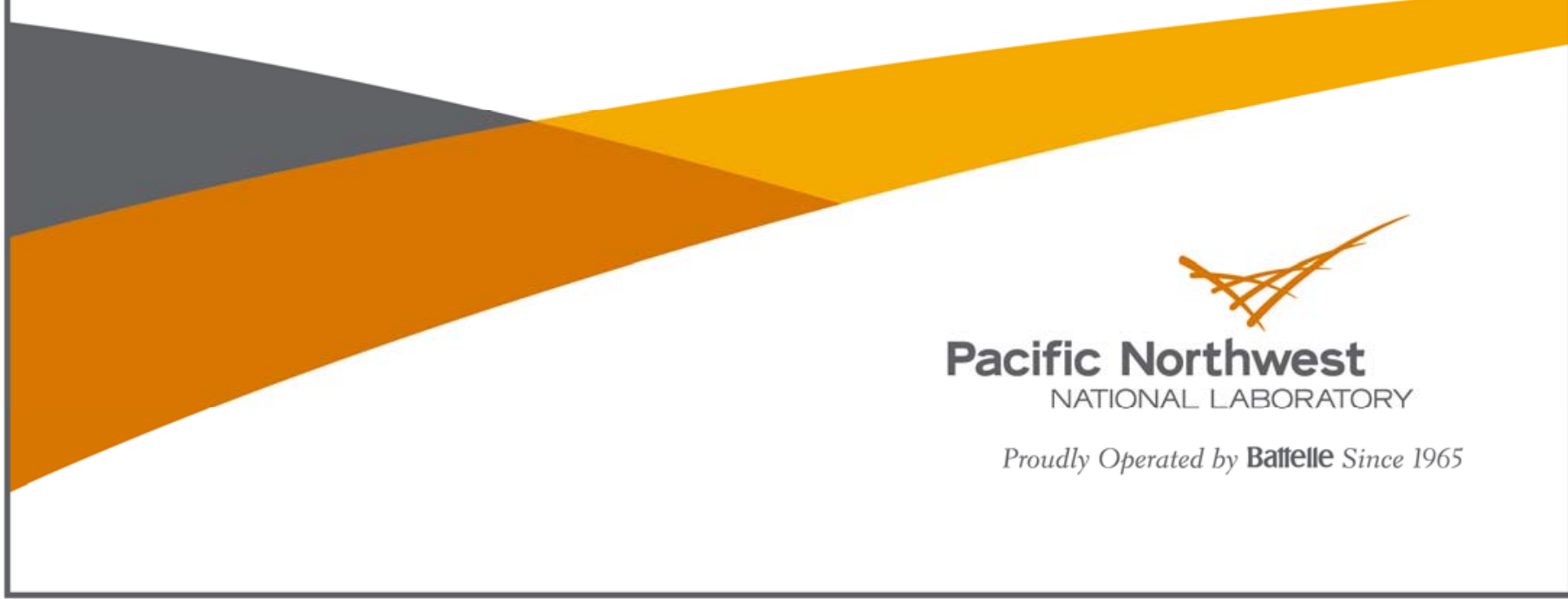




\title{
DISCLAIMER
}

This report was prepared as an account of work sponsored by an agency of the United States Government. Neither the United States Government nor any agency thereof, nor Battelle Memorial Institute, nor any of their employees, makes any warranty, express or implied, or assumes any legal liability or responsibility for the accuracy, completeness, or usefulness of any information, apparatus, product, or process disclosed, or represents that its use would not infringe privately owned rights. Reference herein to any specific commercial product, process, or service by trade name, trademark, manufacturer, or otherwise does not necessarily constitute or imply its endorsement, recommendation, or favoring by the United States Government or any agency thereof, or Battelle Memorial Institute. The views and opinions of authors expressed herein do not necessarily state or reflect those of the United States Government or any agency thereof.

\author{
PACIFIC NORTHWEST NATIONAL LABORATORY \\ operated by \\ BATTELLE \\ for the \\ UNITED STATES DEPARTMENT OF ENERGY \\ under Contract DE-AC05-76RL01830 \\ Printed in the United States of America
Available to DOE and DOE contractors from the Office of Scientific and Technical Information, P.O. Box 62, Oak Ridge, TN 37831-0062; ph: (865) 576-8401 fax: $(865) 576-5728$
email: reports $@$ adonis.osti.gov \\ Available to the public from the National Technical Information Service \\ 5301 Shawnee Rd., Alexandria, VA 22312 \\ ph: (800) 553-NTIS (6847) \\ email: orders@ntis.gov <http://www.ntis.gov/about/form.aspx> \\ Online ordering: http://www.ntis.gov
}




\title{
Investigations into the Nature of Alkaline Soluble, Non-Pertechnetate Technetium
}

\author{
BM Rapko \\ TG Levitskaia \\ SA Bryan \\ JM Peterson \\ $S$ Chatterjee \\ RA Peterson \\ MK Edwards \\ SI Sinkov
}

November 2013

Prepared for

the U.S. Department of Energy

under Contract DE-AC05-76RL01830

Pacific Northwest National Laboratory

Richland, Washington 99352 



\section{Executive Summary}

This report summarizes work accomplished in fiscal year (FY) 2013, exploring the chemistry of a low-valence technetium(I) species, $\left[\mathrm{Tc}(\mathrm{CO})_{3}\left(\mathrm{H}_{2} \mathrm{O}\right)_{3}\right]^{+}$, a compound of interest due to its implication in the speciation of alkaline-soluble technetium in several Hanford tank waste supernatants. Various aspects of FY 2013's work were sponsored both by Washington River Protection Solutions and the U.S. Department of Energy's Office of River Protection; because of this commonality, both sponsors' work is summarized in this report.

There were three tasks in this FY 2013 study. The first task involved examining the speciation of $\left[(\mathrm{CO})_{3} \mathrm{Tc}\left(\mathrm{H}_{2} \mathrm{O}\right)_{3}\right]^{+}$in alkaline solution by ${ }^{99} \mathrm{Tc}$ nuclear magnetic resonance spectroscopy. The second task involved the purchase and installation of a microcalorimeter suitable to study the binding affinity of $\left[(\mathrm{CO})_{3} \mathrm{Tc}\left(\mathrm{H}_{2} \mathrm{O}\right)_{3}\right]^{+}$with various inorganic and organic compounds relevant to Hanford tank wastes, although the actual measure of such binding affinities is scheduled to occur in future FYs. The third task involved examining the chemical reactivity of $\left[(\mathrm{CO})_{3} \mathrm{Tc}\left(\mathrm{H}_{2} \mathrm{O}\right)_{3}\right]^{+}$as relevant to the development of a $\left[(\mathrm{CO})_{3} \mathrm{Tc}\left(\mathrm{H}_{2} \mathrm{O}\right)_{3}\right]^{+}$spectroelectrochemical sensor based on fluorescence spectroscopy.

Key findings from this year's tasks are summarized below:

From Task 1 - Examine the speciation of $\left[(\mathrm{CO})_{3} \mathrm{Tc}\left(\mathrm{H}_{2} \mathrm{O}\right)_{3}\right]^{+}$in alkaline solution by ${ }^{99} \mathrm{Tc}$ nuclear magnetic resonance spectroscopy:

1. Many of the current synthetic procedures for $\left[\mathrm{Tc}(\mathrm{CO})_{3}\left(\mathrm{H}_{2} \mathrm{O}\right)_{3}\right]^{+}$are not suitable for use under the relatively large, milligram-to-gram-sized syntheses required for this work due primarily to various oligiomerization reactions that occur under alkaline conditions with micromolar and higher concentration solutions as well as to the difficulty in purifying the highly water-soluble Tc(I) species from pertechnetate. Significant resources were diverted from other tasks in order to obtain a Tc-tricarbonyl precursor.

2. As noted above, the $\left[\mathrm{Tc}(\mathrm{CO})_{3}\left(\mathrm{H}_{2} \mathrm{O}\right)_{3}\right]^{+}$complex ion exists only in acidic solutions and undergoes extensive hydrolysis starting at about $\mathrm{pH}$ 6.8. The first $\mathrm{p} K_{\mathrm{a}}$ of the $\left[\mathrm{Tc}(\mathrm{CO})_{3}\left(\mathrm{H}_{2} \mathrm{O}\right)_{3}\right]^{+}$complex obtained was estimated to be 7.75. Similar hydrolytic behavior should be anticipated in the alkaline tank waste; therefore, the presence of the $\left[\mathrm{Tc}(\mathrm{CO})_{3}\left(\mathrm{H}_{2} \mathrm{O}\right)_{3}\right]^{+}$itself in the alkaline waste is not viable. Rather its hydrolysis products, of general composition $\left[\mathrm{Tc}(\mathrm{CO})_{3}(\mathrm{OH})_{n}\left(\mathrm{H}_{2} \mathrm{O}\right)_{m}\right]^{1-n}$ in the absence of organic complexing agents, are anticipated to exist in the alkaline waste.

3. The complexation studies of the organic ligands found in the tank waste with $\left[\mathrm{Tc}(\mathrm{CO})_{3}\left(\mathrm{H}_{2} \mathrm{O}\right)_{3}\right]^{+}$is limited to the acidic solutions and are thus not directly applicable to the tank waste chemistry. Under alkaline conditions, such complexation studies are complicated by the hydrolysis of $\left[\mathrm{Tc}(\mathrm{CO})_{3}\left(\mathrm{H}_{2} \mathrm{O}\right)_{3}\right]^{+}$and formation of the multiple $\left[\mathrm{Tc}(\mathrm{CO})_{3}(\mathrm{OH})_{\mathrm{n}}\left(\mathrm{H}_{2} \mathrm{O}\right)_{\mathrm{m}}\right]^{1-\mathrm{n}}$ species. A thorough understanding of $\left[\mathrm{Tc}(\mathrm{CO})_{3}\left(\mathrm{H}_{2} \mathrm{O}\right)_{3}\right]^{+}$hydrolytic behavior and speciation and the quantification of the hydrolysis constants is a necessary prerequisite to properly evaluating the role of alkaline-soluble, low-valence Tc in Hanford tank wastes. This conclusion is supported by previous reports demonstrating that the hydrolysis of the $\left[\mathrm{Tc}(\mathrm{CO})_{3}\left(\mathrm{H}_{2} \mathrm{O}\right)_{3}\right]^{+}$ion interferes with complexation to not only the weakly coordinating halide ligands, but also to stronger ligands such as cyanate and thiocyanate (Gorshkov et al. 2003a,b). 
4. It is estimated that the upper limit of the ${ }^{99} \mathrm{Tc}$ concentration in the aqueous samples containing low-valence Tc is $0.05 \mathrm{mM}$, comparable to or exceeding that found in liquid Hanford tank waste samples. Thus, the obtained information cannot be disqualified as relevant to the in-tank conditions. It is significant that the high hydroxide concentration elevates the solubility of the non-pertechnetate species in the aqueous solution even without organic ligands present. This unexpected result emphasizes the importance of the understanding of the $\mathrm{OH}^{-}$ion coordination with non-pertechnetate Tc in oxidation states lower than VII.

5. It was observed that species containing $\left[\mathrm{Tc}(\mathrm{CO})_{3}\right]^{+}$moiety are unstable with time and eventually convert to pertechnetate. However, their presence has been detected in the aerated supernatants of two Hanford tanks directly and several other tank supernatants indirectly. Therefore, the possibility of regeneration of low-valence species and inter-conversion between the low-valence Tc(I) and other Tc oxidation states, either known to be or assumed to be present in the Hanford tanks, should be tested.

From Task 2 - Purchase and installation of a microcalorimeter suitable to study the binding affinity of $\left[(\mathrm{CO})_{3} \mathrm{Tc}\left(\mathrm{H}_{2} \mathrm{O}\right)_{3}\right]^{+}$with various inorganic and organic compounds relevant to Hanford tank wastes:

6. A TAM III series microcalorimeter from TA Instruments (Waters, LLC) was installed and put into operation in FY 2013. The instrument was calibrated against the well-studied $\mathrm{BaCl}_{2}$ complexation with 18-crown-6 in water. Our results agreed well with the thermodynamic values reported in prior studies (see Section 2.7) and indicated that the microcalorimeter can successfully measure equilibrium constants and heat of complexation reactions in the sub-millimolar concentration range.

From Task 3 - Examine the chemical reactivity of $\left[(\mathrm{CO})_{3} \mathrm{Tc}\left(\mathrm{H}_{2} \mathrm{O}\right)_{3}\right]^{+}$as relevant to the development of a $\left[(\mathrm{CO})_{3} \mathrm{Tc}\left(\mathrm{H}_{2} \mathrm{O}\right)_{3}\right]^{+}$spectroelectrochemical sensor based on fluorescence spectroscopy:

7. We also have demonstrated the ability to convert the non-emissive $\left[\mathrm{Tc}(\mathrm{CO})_{3}\left(\mathrm{H}_{2} \mathrm{O}\right)_{3}\right]^{+}$or $\left[\mathrm{Tc}(\mathrm{CO})_{3}(\mathrm{X})\left(\mathrm{H}_{2} \mathrm{O}\right)\right]^{+}$complexes, where $\mathrm{X}$ is a ligand of varying denticity, into the emissive $\left[\mathrm{Tc}(\mathrm{CO})_{3}(\mathrm{~L} \sim \mathrm{L})\left(\mathrm{H}_{2} \mathrm{O}\right)\right]^{+}$complex $(\mathrm{L} \sim \mathrm{L}=$ bpy or phen), followed by the fluorescence-mode detection of these new species in solution.

8. A subcontract has been initiated with the University of Cincinnati for preparation of polymer film coatings for use in a spectroelectrochemical film device.

9. In summary, in FY 2013 proof-of-principle work was performed successfully for a spectroelectrochemical film device; this involved preparation of two, candidate, low-valence Tc compounds containing this fluorescence-active component and determining each compound's synthesis, characterization, and spectral properties. 


\section{Acronyms and Abbreviations}

BER borohydride ion exchange resin

bpy bipyridine

$\mathrm{CV} \quad$ cyclic voltammogram

DI deionized (water)

FTIR Fourier Transfer Infrared

FY fiscal year

$\mathrm{Hz} \quad$ hertz

NMR nuclear magnetic resonance

PNNL Pacific Northwest National Laboratory

THF tetrahydrofuran

UV ultraviolet

WRPS Washington River Protection Solutions 



\section{Contents}

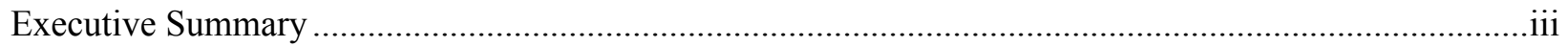

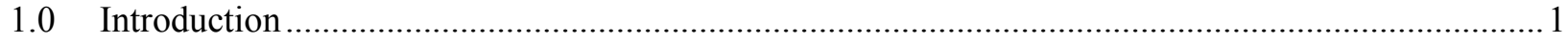

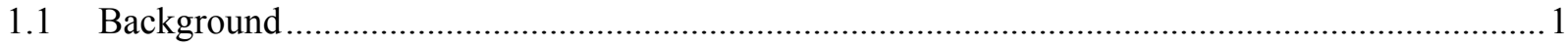

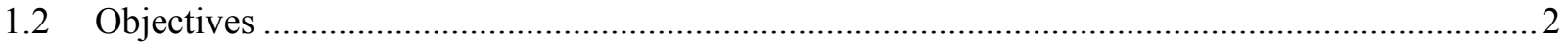

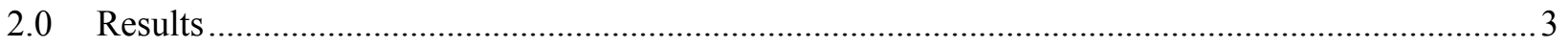

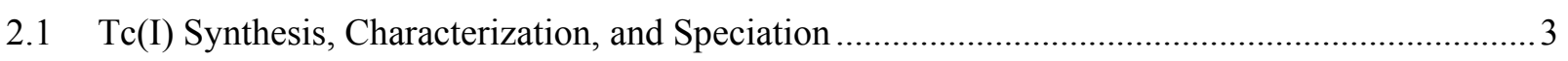

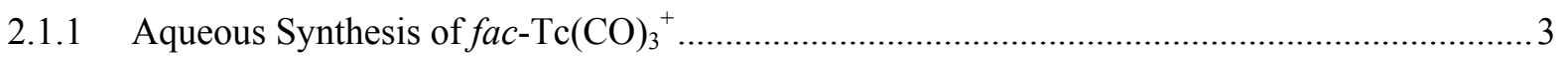

2.1.2 ${ }^{99}$ Tc-NMR Characterization of the Aqueous Reaction Products ............................................5

2.1.3 Time Dependence of Reaction Products in $\left[\mathrm{Tc}(\mathrm{CO})_{3}(\mathrm{OH})\left(\mathrm{H}_{2} \mathrm{O}\right)_{2}\right]$ Syntheses....................... 6

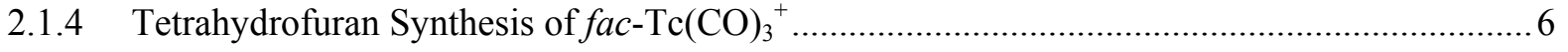

2.1.5 ${ }^{99}$ Tc NMR Characterization of the THF Reaction Product .................................................... 8

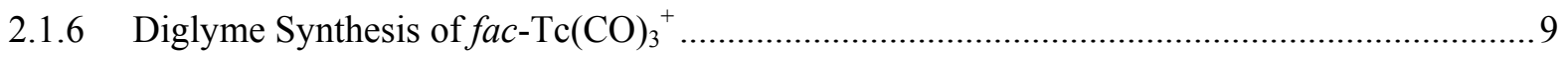

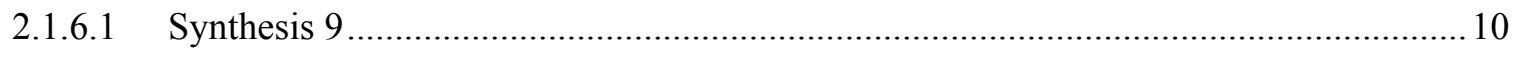

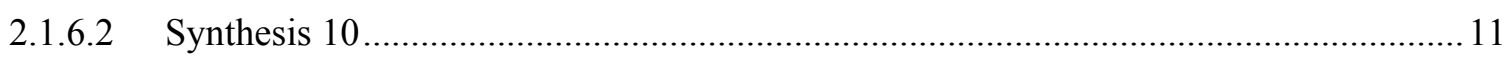

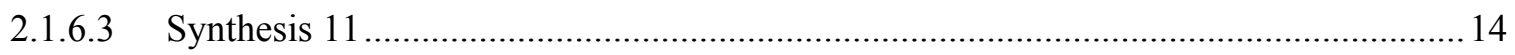

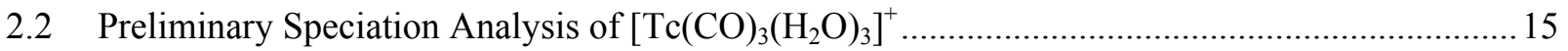

2.3 Preparation and Characterization of the $\left[\mathrm{Tc}(\mathrm{CO})_{3}(\text { gluconate })\right]^{2-}$ Complex.................................20

2.4 Ultraviolet Characterization of the $\left[\mathrm{Tc}(\mathrm{CO})_{3}\right]^{+}$Species....................................................... 21

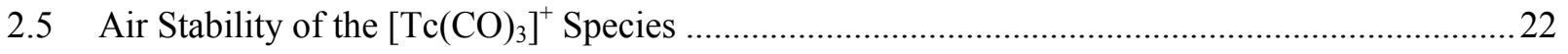

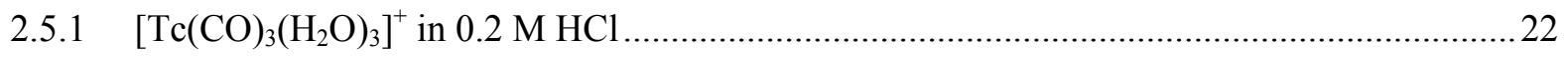

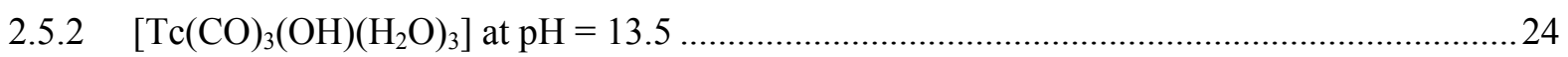

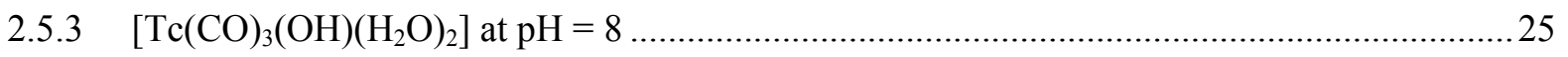

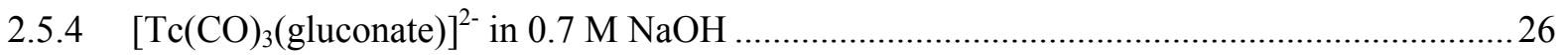

2.6 Discussion of Tc(I) Tricarbonyl Syntheses, Speciation, and Air Stability .................................27

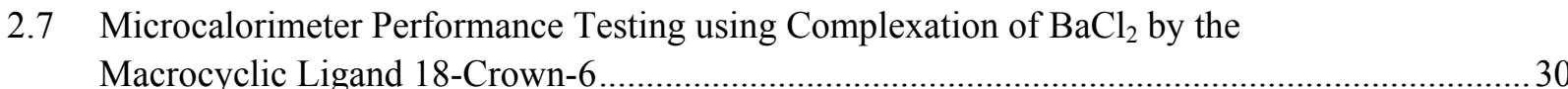

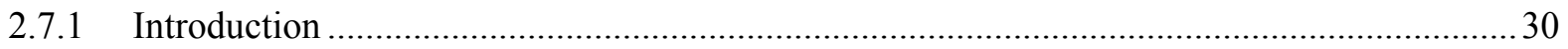

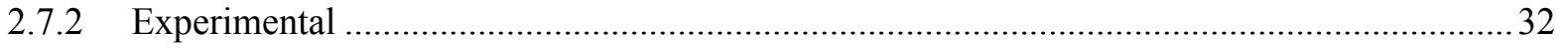

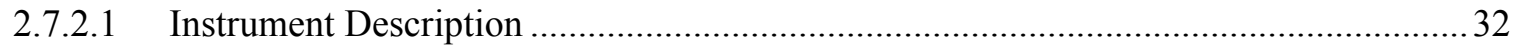

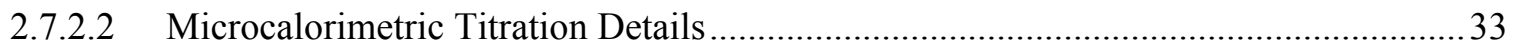

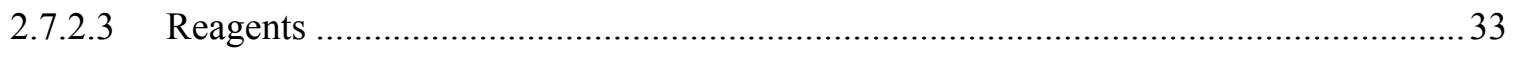

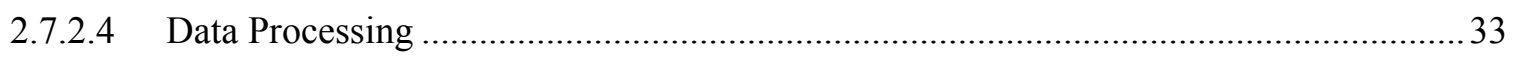

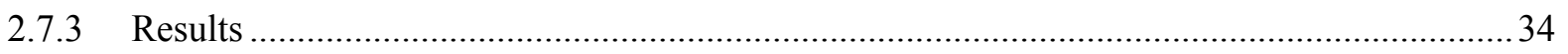




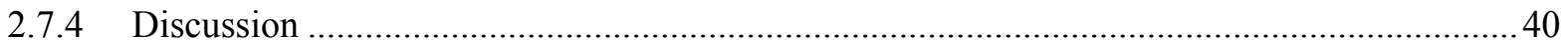

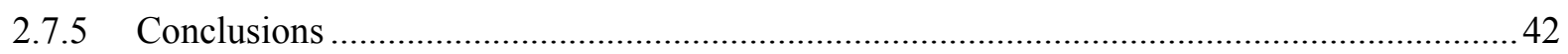

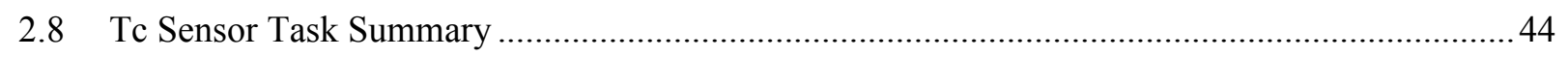

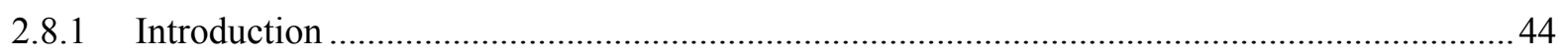

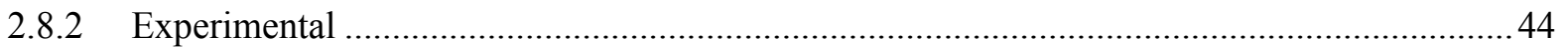

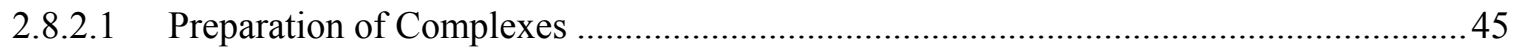

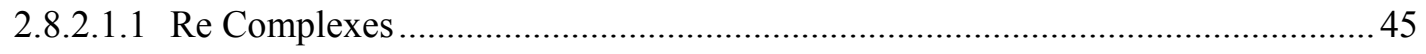

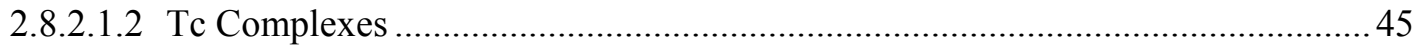

2.8.2.2 Electrochemistry, Spectroscopy, and Spectroelectrochemistry ….............................. 45

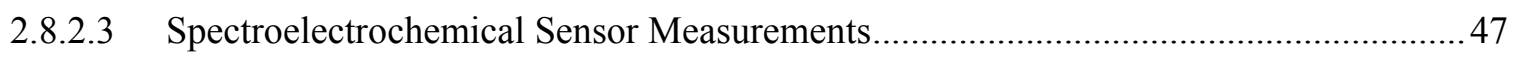

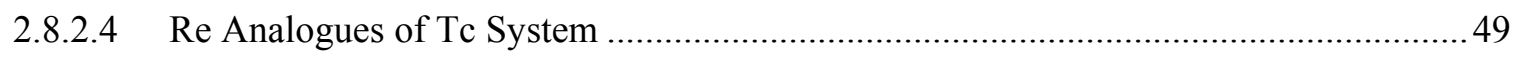

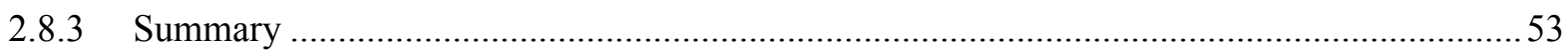

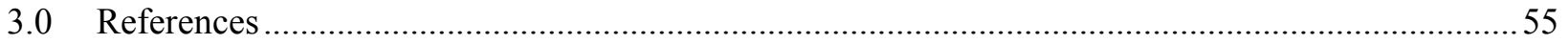




\section{Figures}

1.1. Structures of Pertechnetate Anion and Tri-carbonyl-tris-aqua-Tc(I) Cation 2

2.1. FTIR Spectra of the Liquid Reaction Mixtures from Synthesis 7 and Synthesis 8 and of the Solid Generated from the Reaction Mixture from Synthesis 7 that Contain $\left[\mathrm{Tc}(\mathrm{CO})_{3} \mathrm{Cl}_{3}\right]^{2-}$

Product

2.2. (A) Yellow-brown Solution Formed After Dissolving $\left(\mathrm{Bu}_{4} \mathrm{~N}\right)\left[\mathrm{TcOCl}_{4}\right]$ in Diglyme in Step 2 of Synthesis 9; (B) Dark Brown Solution Resulting from Addition of $\mathrm{BH}_{3}$-THF Solution to $\left(\mathrm{Bu}_{4} \mathrm{~N}\right)\left[\mathrm{TcOCl}_{4}\right]$ in Diglyme

2.3. (A) White-green Precipitate Formed After Warming the Reaction Mixture of Synthesis 9 with $\mathrm{Et}_{4} \mathrm{NCl}$ Overnight at $60^{\circ} \mathrm{C}$; (B) the White-green Precipitate

2.4. (A) Green Solution Formed After Dissolving $\left(\mathrm{Bu}_{4} \mathrm{~N}\right)\left[\mathrm{TcOCl}_{4}\right]$ in Diglyme in Step 2 of Synthesis 10; (B) Dark Brown Solution Resulting from Addition of $\mathrm{BH}_{3}$-THF Solution to $\left(\mathrm{Bu}_{4} \mathrm{~N}\right)\left[\mathrm{TcOCl}_{4}\right]$ in Diglyme; (C) Yellow Solution Generated After Heating the Reaction Mixture at $110^{\circ} \mathrm{C}$ Overnight.

2.5. Infrared Spectrum of White Solid Generated from Synthesis 10.

2.6. ${ }^{99}$ Tc-NMR Spectrum of the White Precipitate Obtained in Synthesis 10 Recorded in $\mathrm{CD}_{3} \mathrm{CN}$....... 13

2.7. Speciation Analysis of $\left[\mathrm{Tc}(\mathrm{CO})_{3}\left(\mathrm{H}_{2} \mathrm{O}\right)_{3}\right]^{+}$as a Function of $\mathrm{pH}$ Using ${ }^{99} \mathrm{Tc}-\mathrm{NMR}$ Spectroscopy ..... 16

2.8. Speciation Distribution of Tc(I)-tricarbonyl Species and Pertechnetate as a Function of $\mathrm{pH}$.......... 19

2.9. $\left[\mathrm{Tc}(\mathrm{CO})_{3}\left(\mathrm{H}_{2} \mathrm{O}\right)_{3}\right]^{+}$Speciation Diagram Obtained in the $\mathrm{pH}$ Titration Experiment. ....................... 20

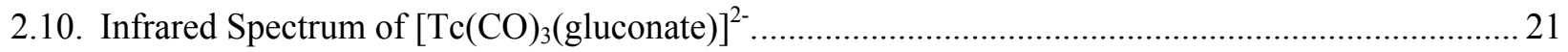

2.11. UV-Visible Spectra of Aqueous Solutions of $\left[\mathrm{Tc}(\mathrm{CO})_{3}\right.$ (gluconate $\left.)\right]^{2-}$ in $0.25 \mathrm{M}$ Potassium Gluconate/0.7 M NaOH, $\left[\mathrm{Tc}(\mathrm{CO})_{3}\left(\mathrm{H}_{2} \mathrm{O}\right)_{3}\right]^{+}$in $0.2 \mathrm{M} \mathrm{HCl},\left[\mathrm{Tc}(\mathrm{CO})_{3}\left(\mathrm{H}_{2} \mathrm{O}\right)_{2}(\mathrm{OH})\right]$ at $\mathrm{pH}=14$,

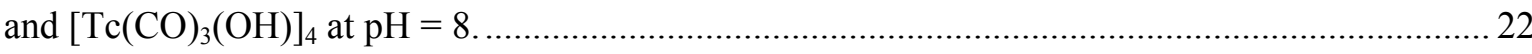

2.12. Monitoring the Stability of $\left[\mathrm{Tc}(\mathrm{CO})_{3}\left(\mathrm{H}_{2} \mathrm{O}\right)_{3}\right]^{+}$Species in $0.2 \mathrm{M} \mathrm{HCl}$ with Time ..........................23

2.13. Spectral Plot of the Stability of $\left[\mathrm{Tc}(\mathrm{CO})_{3}\left(\mathrm{H}_{2} \mathrm{O}\right)_{2}(\mathrm{OH})\right]$ Species at $\mathrm{pH}=13.5$ with Time as

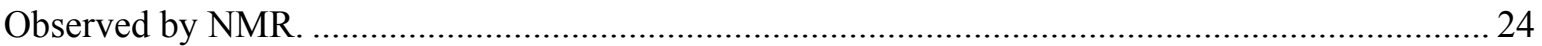

2.14. Monitoring the Stability of $\left[\mathrm{Tc}(\mathrm{CO})_{3}\left(\mathrm{H}_{2} \mathrm{O}\right)_{2}(\mathrm{OH})\right]$ Species at $\mathrm{pH} 8$ with Time............................ 25

2.15. Overlay of ${ }^{99} \mathrm{Tc}-\mathrm{NMR}$ Resonances Observed for the Studied Tc Compounds ................................ 28

2.16. Microcalorimetric Titration Vessel Setup ................................................................................ 32

2.17. Microcalorimetric Titration Experiment at Higher Concentrations of Reactants. .......................... 35

2.18. Microcalorimetric Titration Experiment at Lower Concentrations of Reactants............................ 36

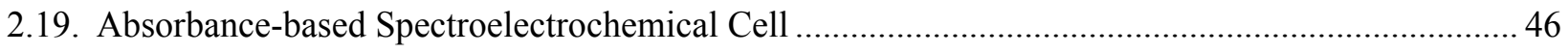

2.20. (A) Schematic Representation of Spectroelectrochemical Setup Using an Aqueous Micro-Drop;

(B) Photograph of the Cell. 
2.21. $\mathrm{CV}$ of $5 \mathrm{mM} \mathrm{Ru}(\mathrm{bpy})_{3}{ }^{2+}$ in $0.1 \mathrm{M} \mathrm{KNO}_{3}$ Using a Pt Mesh Working Electrode, Pt Auxilliary Electrode, and $\mathrm{Ag} / \mathrm{AgCl}$ Reference.

2.22. (A) Modulation of Luminescence Intensity of an Aqueous Solution $x 10^{-3} \mathrm{M}\left[\mathrm{Ru}(\mathrm{bpy})_{3}\right]^{2+}$ in $0.1 \mathrm{M} \mathrm{KNO}_{3}$ with Time on the Application of Voltage $\left(\lambda_{\mathrm{ex}}=532 \mathrm{~nm}\right)$; (B) Nernst Plot of log $[\mathrm{Ox}] /[\mathrm{Red}]$ vs. $\mathrm{E}_{\text {app }}$ vs. $\mathrm{Ag} / \mathrm{AgCl}$ at $620 \mathrm{~nm}$.

2.23. (A) Modulation of $5 \mathrm{mM}\left[\mathrm{Ru}(\mathrm{bpy})_{3}\right]^{2+/ 3+}$ in $0.1 \mathrm{M} \mathrm{KNO}_{3}$ (B) Potential was Modulated Between 1.3 V and 0.8 V Where the Potential was Held for Five Minutes.....

2.24. Emission and Absorption Spectra of $\mathrm{Re}(\mathrm{dbbpy})(\mathrm{CO})_{3} \mathrm{Cl}$

2.25. $\mathrm{CV}$ of $10 \mathrm{mM} \mathrm{Re}(\text { dbbpy)(CO) })_{3} \mathrm{Cl}(\mathrm{B})$ and $10 \mathrm{mM} \operatorname{Re}($ bpy $)(\mathrm{CO})_{3} \mathrm{Cl}(\mathrm{A})$, Both with $0.1 \mathrm{M}$ $\mathrm{TBAPF}_{6}$ in Acetonitrile.

2.26. Absorbance Spectra Obtained Using $2 \mathrm{mM} \mathrm{Re}($ dbbpy $)(\mathrm{CO})_{3} \mathrm{Cl}$ and $0.1 \mathrm{M}$ TBACl Solution in Dimethylforamide (DMF)

2.27. Absorbance Modulation for $2 \mathrm{mM} \operatorname{Re}($ dbbpy $)(\mathrm{CO})_{3} \mathrm{Cl}$ and $0.1 \mathrm{M}$ TBACl Solution in DMF. .51

2.28. Cryogenic Time-Resolved Fluorescence Spectra of $\left[\mathrm{Tc}(\mathrm{CO})_{3}(\text { bpy }) \mathrm{H}_{2} \mathrm{O}\right]^{+}$

2.29. (A) Cryogenic Time-Resolved Fluorescence Spectra of $\left[\mathrm{Tc}(\mathrm{CO})_{3}(\text { bpy })\left(\mathrm{H}_{2} \mathrm{O}\right)\right]^{+}$; (B) Fluorescence spectra of $\left[\mathrm{Tc}(\mathrm{CO})_{3}(\mathrm{bpy})\left(\mathrm{H}_{2} \mathrm{O}\right)\right]^{+}$After Subtraction of the Fluorescence Signature of Phen Starting Material. 


\section{Tables}

2.1. ${ }^{99}$ Tc-NMR Characterization of the Aqueous Reaction Products....................................................... 5

2.2. ${ }^{99}$ Tc-NMR Characterization of the THF Reaction Product from Synthesis 8 ............................... 9

2.3. ${ }^{99}$ Tc-NMR Characterization of the Reaction Mixture Generated in Synthesis 10 ........................ 14

2.4. Characterization of Speciation From $1 \mathrm{~b}$ as a pH Function Observed by ${ }^{99} \mathrm{Tc}-\mathrm{NMR}$

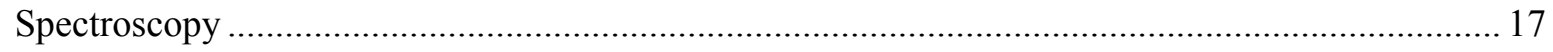

2.5. Characterization of $1 \mathrm{~b}$ Speciation as a pH Function Observed by ${ }^{99} \mathrm{Tc}-\mathrm{NMR}$ Spectroscopy.......... 19

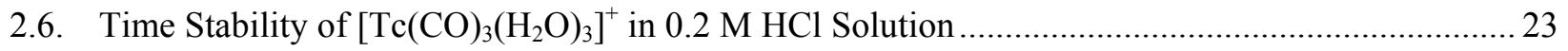

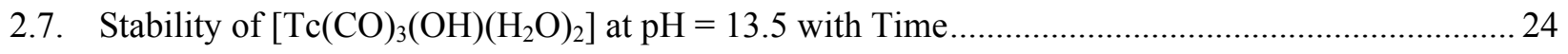

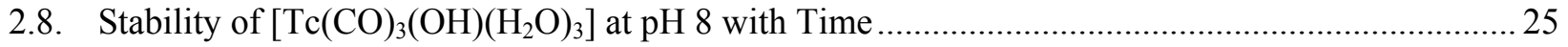

2.9. Monitoring $\left[\mathrm{Tc}(\mathrm{CO})_{3} \text { (gluconate) }\right]^{2-}$ Complex Stability with Time Starting from

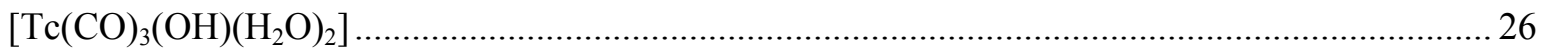

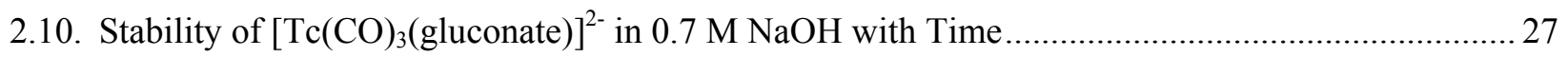

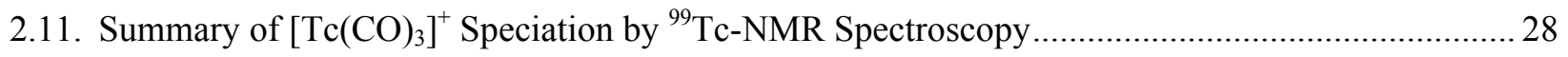

2.12. Summary of Results on $\Delta \mathrm{H}$ and $\mathrm{K}$ Determination from Calorimetric Titration of $8.516 \mathrm{mM}$

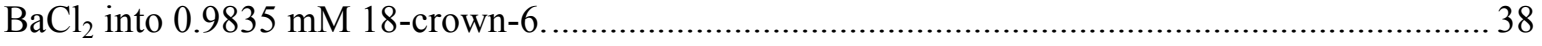

2.13. Summary of Results on $\Delta \mathrm{H}$ and $\mathrm{K}$ Determination from Calorimetric Titration of $8.516 \mathrm{mM}$

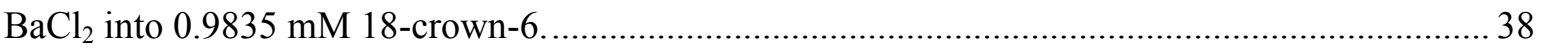

2.14. Summary of Results on $\Delta \mathrm{H}$ and $\mathrm{K}$ Determination from Calorimetric Titration of $16.785 \mathrm{mM}$ $\mathrm{BaCl}_{2}$ into $1.970 \mathrm{mM}$ 18-crown-6

2.15. Summary of Results on $\Delta \mathrm{H}$ and $\mathrm{K}$ Determination from Calorimetric Titration of $16.785 \mathrm{mM}$ $\mathrm{BaCl}_{2}$ into $1.970 \mathrm{mM}$ 18-crown-6.

2.16. Summary of All Titrations Performed in the Course of this Project and Their Comparison with the Instrument Manufacturer and Literature Data. 



\subsection{Introduction}

\subsection{Background}

The fate of ${ }^{99} \mathrm{Tc}$, a Hanford Nuclear Reservation tank waste constituent, is a major River Protection Project flowsheet uncertainty. The key driver to this flowsheet uncertainty is associated with the Integrated Disposal Facility Performance Assessment ${ }^{99} \mathrm{Tc}$ risk determinations. Previous attempts to remove ${ }^{99} \mathrm{Tc}$ from Hanford tank waste using an ion-exchange process specific to pertechnetate $\left(\mathrm{TcO}_{4}{ }^{-}\right.$; Figure 1.1A) were only somewhat successful due to the presence of other valent and complexed forms of ${ }^{99} \mathrm{Tc}$ in the waste supernatant. In fiscal year (FY) 2012, a study reviewed prior work as to the nature and extent of this non-pertechnetate, alkaline-soluble Tc in the Hanford waste tanks (Rapko et al. 2013). As noted in this 2013 report, prior work has identified a Tc(I) carbonyl-type compound as a non-pertechnetate species present in tank waste.

The work covered in this report describes several basic research tasks undertaken to further our understanding of these non-pertechnetate species' various chemical properties. These tasks all worked toward several goals related by the nature of the primary compound of interest, the $\mathrm{Tc}(\mathrm{I})$ tri-carbonyl-tris-aqua compound $\left(\left[(\mathrm{CO})_{3} \mathrm{Tc}\left(\mathrm{H}_{2} \mathrm{O}\right)_{3}\right]^{+}\right.$; Figure 1.1B).

The work scope covered in this report was supported by two sources. One funding agency was Washington River Protection Solutions (WRPS), which supports some Tc(I) sensor development described below as well as the study of the alkaline behavior of Figure 1.1B described below. This work was performed under the WRPS Statement of Work Award 36437-137, Requisition \#: 250881, and was performed under Pacific Northwest National Laboratory (PNNL) Test Plan EMSP-0005, Rev. 1.0.

Later in FY 2013, a joint formal report by PNNL and Savannah River National Laboratory (Brown and Wilmarth et al. 2013) summarized technical issues associated with development of low-temperature waste forms for immobilization of U.S. Department of Energy aqueous waste streams, along with Tc removal, as an implementing technology. In response to this report, the Department of Energy's Office of River Protection sponsored work on low-valence Tc as summarized in PNNL Test Plan EMSP-0006, Rev.0.0. This work focused largely on a proof-of-principle demonstration of the chemistry underlying the development of a spectroelectrochemical sensor for

Figure 1.1B as well as the purchase, installation, and demonstration of a microcalorimeter suitable for eventual use in measuring the binding affinities of organic and inorganic ligands with Figure 1.1B. It should be noted that the large scale synthesis and characterization of Figure 1.1B is an effort that underlies both sponsors' projects.

This report describes research activities performed under both Office of River Protection and WRPS sponsorships and fulfills the milestone of a PNNL formal report describing FY 2013 research activities present in both projects. 
PNNL-22957

EMSP-RPT-018

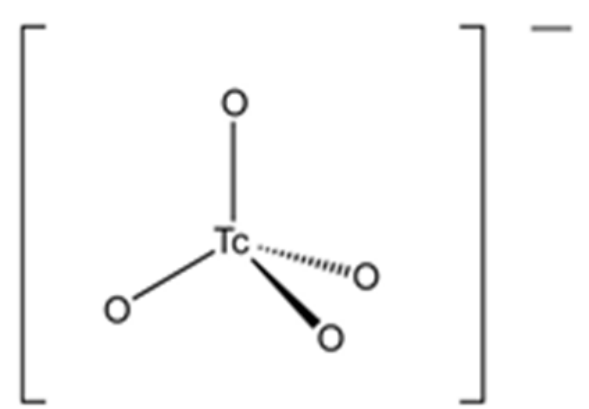

(A)

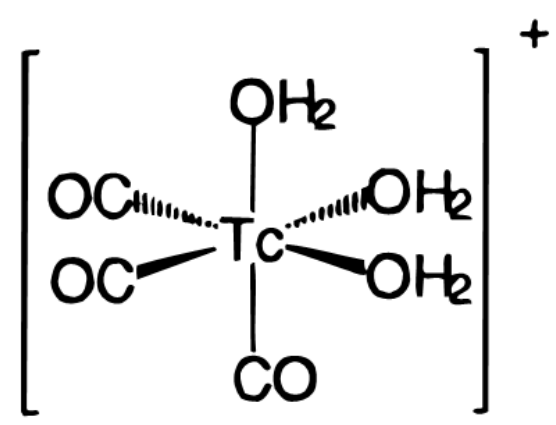

(B)

Figure 1.1. Structures of Pertechnetate Anion (A) and Tri-carbonyl-tris-aqua-Tc(I) Cation (B)

\subsection{Objectives}

This report describes several investigations linked by a common theme: to investigate aspects of the nature and chemistry of the low-valence $\mathrm{Tc}(\mathrm{I})$ species $\left[(\mathrm{CO})_{3} \mathrm{Tc}\left(\mathrm{H}_{2} \mathrm{O}\right)_{3}\right]^{+}$shown in Figure 1.1B, with emphasis on its reactivity in alkaline solution. Three tasks were set up to perform the work described in this report. One involved obtaining and setting up a microcalorimeter suitable for studying the binding affinity of inorganic and organic molecules relevant to tank waste chemistry with compound 1.1B.

A second task involved initial studies on the reactivity, spectral, and electrochemical properties of 1.1B with bipyridyl ligands. Work performed in this task study was designed to support the eventual development of a spectroelectrochemical film device.

The third task involved optimizing the preparation and investigating the chemistry of compound 1.1B by itself in alkaline solution. The primary tool for investigating this work was ${ }^{99} \mathrm{Tc}$ nuclear magnetic resonance (NMR) spectroscopy, supported by selected potentiometric titrations and infrared spectroscopic measurements. It is worth noting that work in this task provides information of value not only in itself but provides basic information of use to the other two tasks.

The results described in the report are organized by task based primarily on the effort invested in each task and goes in the order of the synthesis of $1.1 \mathrm{~B}, \mathrm{pH}$-dependent speciation of $1.1 \mathrm{~B}$ in aqueous solution, setup and performance testing of the calorimeter, and initial studies on the spectroelectrochemical properties of the product of 1.1B with bipyridyl ligands. 


\subsection{Results}

\subsection{Tc(I) Synthesis, Characterization, and Speciation}

\subsubsection{Aqueous Synthesis of $\mathrm{fac}-\mathrm{Tc}(\mathrm{CO})_{3}{ }^{+}$}

A key and major part of the work performed in FY 2013 involved optimization of the synthetic procedure for obtaining analytical quantities of the $f a c-T c(C O){ }_{3}{ }^{+}$as its triaqua complex $(1 \mathrm{~b})$. Our prior results, as described in our FY 2012 report (Rapko et al. 2013) indicated that the Tc(I) tricarbonyl species can be obtained by reducing $\mathrm{TcO}_{4}{ }^{-}$with sodium borohydride in the presence of $\mathrm{CO}$ under alkaline conditions and elevated temperature $\left(50-80^{\circ} \mathrm{C}\right)$ in accordance with the synthetic method reported elsewhere (Alberto et al. 1998a; 1998b).

The expected reduction reaction, from Alberto et al., can be described by Equation 1.

$$
\mathrm{TcO}_{4}{ }^{-}+3 \mathrm{H}_{2} \mathrm{O} \quad \stackrel{\mathrm{NaBH}_{4}, \mathrm{CO}}{\text { tartrate }} \quad\left[\mathrm{Tc}(\mathrm{CO})_{3}\left(\mathrm{H}_{2} \mathrm{O}\right)_{3}\right]^{+}
$$

One drawback of this method is that the reaction usually happens in the presence of a ligand, tartrate, which stabilizes the intermediate $\mathrm{Tc}(\mathrm{V})$ compound. It is difficult to separate this added ligand from the final product; therefore, an initial synthetic investigation was undertaken to test whether it is possible to reduce $\mathrm{TcO}_{4}{ }^{-}$without the presence of a stabilizing ligand, to verify whether either reaction could be scaled up to more synthetically useful amounts, and to characterize the final reduction product(s).

Synthesis 1. The solid $\mathrm{Na}_{2} \mathrm{CO}_{3}(0.43 \mathrm{~g}, 3.9 \mathrm{mMol})$ and $\mathrm{NaBH}_{4}(0.51 \mathrm{~g}, 13 \mathrm{mMol})$ salts were mixed, flushed with $\mathrm{CO}$ for 30 minutes in the reaction vessel, and the solids dissolved in $9 \mathrm{ml}$ of deionized (DI) water. To this solution was added $1 \mathrm{ml}$ of a $16.5-\mathrm{mM} \mathrm{KTcO}_{4}$ solution in water (obtained by dissolving a known amount of potassium pertechnetate, which in turn was obtained from PNNL stocks) and the reaction solution subjected to slow heating. About 5 minutes after the $\mathrm{TcO}_{4}{ }^{-}$addition, the reaction mixture turned intensely pink. This pink color rapidly changed to dark wine color and then to dark brown. At this point, a large amount of dark grey (almost black) precipitate was formed. It is worth noting here that Rard (1983) suggested that this observed pink color corresponds to the unstable $\mathrm{Tc}(\mathrm{V})$ intermediate species, $\mathrm{TcO}_{4}{ }^{3-}$, which is formed by the reduction of $\mathrm{TcO}_{4}{ }^{-}$in alkaline solution.

The reaction mixture was kept at about $75-80^{\circ} \mathrm{C}$ for about four hours and then allowed to cool back to room temperature. The liquid phase was decanted from the precipitate and separated into three subsamples. The subsample containing the original reaction solution had a $\mathrm{pH}$ of about 12 and was not adjusted. The second subsample was neutralized to a $\mathrm{pH}$ of 7 with $1 \mathrm{M}$ hydrochloric acid. To the third subsample, $5 \mathrm{M} \mathrm{NaOH}$ solution was added to adjust the $\mathrm{OH}^{-}$concentration to about $1.8 \mathrm{M}$. Sufficient $\mathrm{D}_{2} \mathrm{O}$ was added to each subsample so that resulting solutions, now suitable for NMR analysis, contained a $\mathrm{H}_{2} \mathrm{O}$-to- $\mathrm{D}_{2} \mathrm{O}$ ratio of $3: 1$.

Synthesis 2. The solid $\mathrm{Na}_{2} \mathrm{CO}_{3}(0.43 \mathrm{~g}, 3.9 \mathrm{mMol})$ and $\mathrm{NaBH}_{4}(0.51 \mathrm{~g}, 13 \mathrm{mMol})$ salts were mixed, flushed with $\mathrm{CO}$ for 30 minutes inside the reaction vessel, and dissolved in $9 \mathrm{ml}$ of DI water. To the solution $0.1 \mathrm{ml}$ of $16.5 \mathrm{mM} \mathrm{TcO}_{4}{ }^{-}$solution was added (10 times less than in Synthesis 1 , in an attempt to 
avoid the previously observed precipitation) and the reaction mixture was subjected to slow heating. Approximately 5 minutes after the addition of $\mathrm{TcO}_{4}{ }^{-}$, the reaction mixture turned pink. This pink color rapidly changed to brown. No visible precipitate was formed at this time. The reaction mixture was maintained at $\sim 75-80^{\circ} \mathrm{C}$ for about three hours, cooled to room temperature, and separated into three subsamples. The subsample containing original reaction solution had a $\mathrm{pH}$ of about 12 and was left unchanged. The second subsample was acidified to a $\mathrm{pH}$ of 5 with $1 \mathrm{M} \mathrm{HCl}$. To the third subsample, $5 \mathrm{M} \mathrm{NaOH}$ solution was added to adjust $\mathrm{OH}^{-}$concentration to about $1.8 \mathrm{M}$. Sufficient $\mathrm{D}_{2} \mathrm{O}$ was added to each subsample so that resulting solutions, now suitable for NMR analysis, contained a $\mathrm{H}_{2} \mathrm{O}-$ to- $\mathrm{D}_{2} \mathrm{O}$ ratio of $3: 1$.

Synthesis 3. This synthesis tested the effect of the carbonate buffer on the reaction product. The carbonate presented in earlier syntheses was substituted here with $0.01 \mathrm{M} \mathrm{NaOH}$ solution to keep the $\mathrm{pH}$ of the reaction mixture at 12 . Specifically, solid $\mathrm{NaBH}_{4}(0.52 \mathrm{~g}, 13 \mathrm{mMol})$ was introduced, the apparatus flushed with $\mathrm{CO}$ for 30 minutes, and the solid dissolved in $9 \mathrm{ml}$ of $0.01-\mathrm{M} \mathrm{NaOH}$ solution. To this solution was added $0.1 \mathrm{ml}$ of $16.5 \mathrm{mM} \mathrm{TcO}_{4}{ }^{-}$solution. Immediately after the addition, the reaction mixture turned from colorless to light pink ( $\sim 5$ minutes) and then dark grey ( $\sim 15$ minutes) with the concomitant formation of a black precipitate. The reaction mixture was held at $\sim 75-80^{\circ} \mathrm{C}$ for about two hours and then allowed to cool to room temperature. The liquid phase was decanted from the precipitate and separated into the three subsamples. The first subsample, with a $\mathrm{pH}$ of about 12, was not changed. The second subsample was acidified to a $\mathrm{pH}$ of 2 with $1 \mathrm{M} \mathrm{HCl}$. To the third subsample, $5 \mathrm{M} \mathrm{NaOH}$ solution was added to adjust the $\mathrm{OH}^{-}$concentration to about $1.8 \mathrm{M}$. Sufficient $\mathrm{D}_{2} \mathrm{O}$ was added to each subsample so that resulting solutions, now suitable for NMR analysis, contained a $\mathrm{H}_{2} \mathrm{O}-$ to- $-\mathrm{D}_{2} \mathrm{O}$ ratio of $3: 1$.

Synthesis 4. In this synthesis, borohydride ion exchange resin (BER) was used as the source of $\mathrm{BH}_{4}{ }^{-}$ instead of $\mathrm{NaBH}_{4}$. The synthesis was conducted following the procedure reported in Park et al. (2005). The solid $\mathrm{NaHCO}_{3}(1.1 \mathrm{~g})$ salt and BER $(6 \mathrm{~g})$ were mixed and flushed with $\mathrm{CO}$ for 1 hour in the reaction vessel. One milliliter of $16.5-\mathrm{mM} \mathrm{TcO}_{4}{ }^{-}$solution was added to $9 \mathrm{ml}$ of DI water. This solution was added slowly to the solid and the resulting suspension was subjected to slow heating. About 5 minutes after the addition of $\mathrm{TcO}_{4}{ }^{-}$the reaction mixture turned intensely pink. The pink color rapidly changed to a dark purple color. No precipitate was observed. The reaction mixture was maintained at $\sim 75-80^{\circ} \mathrm{C}$ for about two hours and cooled to room temperature overnight. The reaction turned into purple goo overnight. Ten milliliters of $1 \mathrm{M}-\mathrm{NaCl}$ was added to dissolve the goo. The liquid phase was decanted from the BER and the $\mathrm{pH}$ was measured at $\sim 11$. Sufficient $\mathrm{D}_{2} \mathrm{O}$ was added so that the resulting solution, now suitable for NMR analysis, contained a $\mathrm{H}_{2} \mathrm{O}$-to- $\mathrm{D}_{2} \mathrm{O}$ ratio of $3: 1$.

Synthesis 5. In this synthesis, boranocarbonate $\left(\mathrm{Na}_{2} \mathrm{BH}_{3} \mathrm{CO}_{2}\right)$ was used as an in situ source of $\mathrm{CO}$ and simultaneous reductant for $\mathrm{TcO}_{4}{ }_{4}^{-}$. The synthesis was conducted following the procedure reported by Alberto et al. (2001). The solid $\mathrm{Na}_{2} \mathrm{CO}_{3}(0.11 \mathrm{~g}, 0.95 \mathrm{mMol})$ and $\mathrm{Na}_{2} \mathrm{BH}_{3} \mathrm{CO}_{2}(0.5 \mathrm{~g}, 5 \mathrm{mMol})$ salts were mixed and the reaction vessel flushed with $\mathrm{CO}$ for one hour. One-half milliliter of $16.5-\mathrm{mM} \mathrm{TcO}_{4}{ }^{-}$ solution was added to $9.5 \mathrm{ml}$ of DI water and the solution was added to the reaction flask. The reaction mixture was subjected to slow heating. About 5 minutes after the $\mathrm{TcO}_{4}{ }^{-}$was added, the reaction mixture turned intensely purple. No precipitate was observed. The reaction mixture was kept at $\sim 75-80^{\circ} \mathrm{C}$ for about two hours, then allowed to cool to room temperature. 


\subsection{2 ${ }^{99}$ Tc-NMR Characterization of the Aqueous Reaction Products}

The NMR solutions were placed in capped polytetrafluoroethylene/fluorinated ethylene propylene copolymer sleeves (Wilmad), which were then inserted into $10 \mathrm{~mm}$ glass NMR tubes to provide secondary containment of the radioactive liquids. ${ }^{99} \mathrm{Tc}-\mathrm{NMR}$ data were collected at 67.565 megahertz on a Tecmag Discovery spectrometer equipped with a $10-\mathrm{mm}$ broadband Nalorac probe as described in Cho et al. (2004). Solution containing $5 \mathrm{mM} \mathrm{TcO}_{4}{ }^{-}$was used as a ${ }^{99} \mathrm{Tc}$ chemical shift reference and all chemical shift data (Table 2.1) are quoted relative to $\mathrm{TcO}_{4}{ }^{-}$(Franklin et al. 1982). Each spectrum was acquired using two windows of 150,000 hertz $(\mathrm{Hz})$ to verify the simultaneous presence of the Tc(VII) and $\mathrm{Tc}(\mathrm{I})$ species, and thus the efficiency of any $\mathrm{Tc}(\mathrm{VII})$ reduction. The observed ${ }^{99} \mathrm{Tc}$ resonances are listed in Table 2.1.

Table 2.1. ${ }^{99}$ Tc-NMR Characterization of the Aqueous Reaction Products

\begin{tabular}{|c|c|c|c|c|}
\hline Synthesis & $\begin{array}{l}\text { Solution } \\
\text { Acidity }\end{array}$ & $\begin{array}{c}\text { Chemical Shift of } \\
\text { 99Tc } \\
\text { Resonance, ppm }\end{array}$ & $\begin{array}{l}\text { Half-width of }{ }^{99} \mathrm{Tc} \\
\text { Resonance, } \mathrm{Hz}\end{array}$ & $\begin{array}{l}\text { Assignment of }{ }^{99} \mathrm{Tc} \\
\text { Resonance }\end{array}$ \\
\hline \multirow{3}{*}{1} & $\mathrm{pH}=7$ & -960 & 100 & $?$ \\
\hline & $\mathrm{pH}=12$ & -1062 & 100 & {$\left[\mathrm{Tc}(\mathrm{CO})_{3}(\mathrm{OH})\left(\mathrm{H}_{2} \mathrm{O}\right)_{2}\right]^{\mathrm{a}, \mathrm{b}}$} \\
\hline & {$\left[\mathrm{OH}^{-}\right]=1.8 \mathrm{M}$} & $\begin{array}{l}-1062 \\
-1482\end{array}$ & $\begin{array}{l}90 \\
40\end{array}$ & $\begin{array}{c}{\left[\mathrm{Tc}(\mathrm{CO})_{3}(\mathrm{OH})\left(\mathrm{H}_{2} \mathrm{O}\right)_{2}\right]^{\mathrm{a}, \mathrm{b}}} \\
{\left[\mathrm{Tc}(\mathrm{CO})_{3}(\mathrm{OH})_{3}\right]^{2-} ?}\end{array}$ \\
\hline \multirow[t]{3}{*}{2} & $\mathrm{pH}=5$ & $\begin{array}{l}-865 \\
-901\end{array}$ & $\begin{array}{l}70 \\
70\end{array}$ & $\begin{array}{c}{\left[\mathrm{Tc}(\mathrm{CO})_{3}\left(\mathrm{H}_{2} \mathrm{O}\right)_{3}\right]^{+\mathrm{a}, \mathrm{b}}} \\
{\left[\mathrm{Tc}(\mathrm{CO})_{4}\left(\mathrm{H}_{2} \mathrm{O}\right)_{2}\right]^{+\mathrm{a}}}\end{array}$ \\
\hline & $\mathrm{pH}=12$ & -1061 & 100 & {$\left[\mathrm{Tc}(\mathrm{CO})_{3}(\mathrm{OH})\left(\mathrm{H}_{2} \mathrm{O}\right)_{2}\right]^{\mathrm{a}, \mathrm{b}}$} \\
\hline & {$\left[\mathrm{OH}^{-}\right]=1.8 \mathrm{M}$} & $\begin{array}{c}-1065 \\
1146 \\
-1482\end{array}$ & $\begin{array}{c}100 \\
100 \\
30\end{array}$ & $\begin{array}{c}{\left[\mathrm{Tc}(\mathrm{CO})_{3}(\mathrm{OH})\left(\mathrm{H}_{2} \mathrm{O}\right)_{2}\right]^{\mathrm{a}, \mathrm{b}}} \\
{\left[\mathrm{Tc}(\mathrm{CO})_{3}(\mathrm{OH})_{2}\left(\mathrm{H}_{2} \mathrm{O}\right)\right]^{-\mathrm{a}}} \\
\quad\left[\mathrm{Tc}(\mathrm{CO})_{3}(\mathrm{OH})_{3}\right]^{2-} ?\end{array}$ \\
\hline \multirow[t]{3}{*}{3} & $\mathrm{pH}=2$ & $\begin{array}{l}-864 \\
-903\end{array}$ & $\begin{array}{l}50 \\
70\end{array}$ & $\begin{array}{c}{\left[\mathrm{Tc}(\mathrm{CO})_{3}\left(\mathrm{H}_{2} \mathrm{O}\right)_{3}\right]^{+\mathrm{a}, \mathrm{b}}} \\
{\left[\mathrm{Tc}(\mathrm{CO})_{4}\left(\mathrm{H}_{2} \mathrm{O}\right)_{2}\right]^{+\mathrm{a}}}\end{array}$ \\
\hline & $\mathrm{pH}=12$ & $\begin{array}{l}-1059 \\
-1536\end{array}$ & $\begin{array}{c}100 \\
80\end{array}$ & $\begin{array}{c}{\left[\mathrm{Tc}(\mathrm{CO})_{3}(\mathrm{OH})\left(\mathrm{H}_{2} \mathrm{O}\right)_{2}\right]^{\mathrm{a}, \mathrm{b}}} \\
?\end{array}$ \\
\hline & {$\left[\mathrm{OH}^{-}\right]=1.8 \mathrm{M}$} & $\begin{array}{l}-1065 \\
1146 \\
-1482\end{array}$ & $\begin{array}{c}100 \\
100 \\
25\end{array}$ & $\begin{array}{c}{\left[\mathrm{Tc}(\mathrm{CO})_{3}(\mathrm{OH})\left(\mathrm{H}_{2} \mathrm{O}\right)_{2}\right]^{\mathrm{a}, \mathrm{b}}} \\
{\left[\mathrm{Tc}(\mathrm{CO})_{3}(\mathrm{OH})_{2}\left(\mathrm{H}_{2} \mathrm{O}\right)\right]^{-\mathrm{a}}} \\
\quad\left[\mathrm{Tc}(\mathrm{CO})_{3}(\mathrm{OH})_{3}\right]^{2-} ?\end{array}$ \\
\hline 4 & $\mathrm{pH}=12$ & -1.48 & 50 & $\mathrm{TcO}_{4}^{-}$ \\
\hline
\end{tabular}

Assignment of the ${ }^{99} \mathrm{Tc}$ resonances were based on comparison of the observed chemical shifts and band half-widths with those reported elsewhere (Gorshkov et al. 2000; Alberto et al. 1998c).

For original reaction mixtures $(\mathrm{pH}=12)$ obtained in Syntheses 1 through 3 (performed using $\mathrm{BH}_{4}{ }^{-}$as the pertechnetate reductant), a ${ }^{99} \mathrm{Tc}-\mathrm{NMR}$ resonance at around -1059 to $-1065 \mathrm{ppm}$ was observed, corresponding to the $\left[\mathrm{Tc}(\mathrm{CO})_{3}(\mathrm{OH})\left(\mathrm{H}_{2} \mathrm{O}\right)_{2}\right]$ species. It was the only resonance found in the spectra corresponding to the original reaction mixtures of Syntheses 1 and 2. The original reaction mixture generated during Synthesis 3 exhibited an additional resonance at $-1536 \mathrm{ppm}$, but this resonance has not been identified. 
Acidification of the reaction mixture to the neutral $\mathrm{pH}$ of 7 (Synthesis 1) shifted the ${ }^{99} \mathrm{Tc}$ resonance to $-960 \mathrm{ppm}$. Further acidification to $\mathrm{pH}$ values of 5 and 2 (Syntheses 2 and 3, respectively) resulted in the disappearance of the band corresponding to the $\left[\mathrm{Tc}(\mathrm{CO})_{3}(\mathrm{OH})\left(\mathrm{H}_{2} \mathrm{O}\right)_{2}\right]$ species and generation of two ${ }^{99} \mathrm{Tc}$ resonances at around -865 and $-902 \mathrm{ppm}$. These signals are assigned to the $\left[\mathrm{Tc}(\mathrm{CO})_{3}\left(\mathrm{H}_{2} \mathrm{O}\right)_{3}\right]^{+}$and $\left[\mathrm{Tc}(\mathrm{CO})_{4}\left(\mathrm{H}_{2} \mathrm{O}\right)_{2}\right]^{+}$species, respectively.

Reaction mixtures containing higher $\mathrm{OH}^{-}$concentrations $(1.8 \mathrm{M})$ exhibited resonances at about -1060 ppm (Syntheses 1 through 3), -1146 ppm (Syntheses 2 and 3), and -1482 ppm (Syntheses 1 through 3). Resonances at -1060 and $-1146 \mathrm{ppm}$ correspond to the $\left[\mathrm{Tc}(\mathrm{CO})_{3}(\mathrm{OH})\left(\mathrm{H}_{2} \mathrm{O}\right)_{2}\right]$ species previously observed and a new species, $\left[\mathrm{Tc}(\mathrm{CO})_{3}(\mathrm{OH})_{2}\left(\mathrm{H}_{2} \mathrm{O}\right)\right]^{-}$, respectively. The resonance at $-1482 \mathrm{ppm}$ has not been reported previously in the literature. However, based on its unusually narrow profile with half-width of approximately 25 to $40 \mathrm{~Hz}$, it was concluded that it corresponds to a species of high symmetry and was tentatively assigned to $\left[\mathrm{Tc}(\mathrm{CO})_{3}(\mathrm{OH})_{3}\right]^{2-}$.

For the reaction mixture obtained by Synthesis 4 using BER reductant, only the resonance corresponding to the $\mathrm{TcO}_{4}{ }^{-}$reactant was found. One possible reason for the absence of the additional ${ }^{99} \mathrm{Tc}$ resonances in the spectrum of this reaction mixture may be the reduction of $\mathrm{Tc}(\mathrm{VII})$ only down to $\mathrm{Tc}(\mathrm{VI}$, IV, and/or II). These species of Tc possess an even oxidation state and are ${ }^{99} \mathrm{Tc}-\mathrm{NMR}$-inactive (Mikhalev 2005). Based on the color of the reaction mixture, it is concluded that similar products were formed during Synthesis 5.

\subsubsection{Time Dependence of Reaction Products in $\left[\mathrm{Tc}(\mathrm{CO})_{3}(\mathrm{OH})\left(\mathrm{H}_{2} \mathrm{O}\right)_{2}\right]$ Syntheses}

We observed that with time, precipitates appear in all subsamples of the reaction products.

In subsamples with a $\mathrm{pH} \leq 5$, gel-like precipitates of a sandy or light brownish color were formed within about 48 hours. This precipitation cannot be explained by simple sample hydrolysis because the $\mathrm{pH}$ was significantly acidic and outside the reported hydrolysis zone. The most plausible explanation for this precipitate formation is low stability of the $\left[\mathrm{Tc}(\mathrm{CO})_{3}\left(\mathrm{H}_{2} \mathrm{O}\right)_{3}\right]^{+}$and/or $\left[\mathrm{Tc}(\mathrm{CO})_{4}\left(\mathrm{H}_{2} \mathrm{O}\right)_{2}\right]^{+}$species and consequent oxidation of $\mathrm{Tc}(\mathrm{I})$ to poorly soluble compound(s) with higher Tc oxidation states by atmospheric oxygen.

The original reaction mixtures in which $\mathrm{pH}$ remained at approximately 12 also formed significant amounts of dark grey precipitate upon standing. Specifically, smaller amounts of dark grey precipitate were developed in the reaction product solutions containing $\mathrm{OH}^{-}$concentration of $1.8 \mathrm{M}$. Formation of these precipitates can be explained by proposing the formation of polynuclear $\mathrm{Tc}(\mathrm{I})$ hydrolysis species with poor aqueous solubility and/or air-oxidation of $\mathrm{Tc}(\mathrm{I})$ in the $\left[\mathrm{Tc}(\mathrm{CO})_{3}(\mathrm{OH})\left(\mathrm{H}_{2} \mathrm{O}\right)_{2}\right]$ species and formation of poorly soluble $\mathrm{TcO}_{2}$.

It was also observed that washing the dark grey precipitates formed during Syntheses 1 and 3 with aqueous 5-M NaOH resulted in their partial dissolution into the $\mathrm{NaOH}$ solution accompanied by a color change in the solution from colorless to brownish.

\subsubsection{Tetrahydrofuran Synthesis of $\mathrm{fac}-\mathrm{Tc}(\mathrm{CO})_{3}{ }^{+}$}

To overcome the complications associated with the aqueous synthesis of $\left[\mathrm{Tc}(\mathrm{CO})_{3}\left(\mathrm{H}_{2} \mathrm{O}\right)_{3}\right]^{+}$, the synthetic effort shifted to syntheses using an organic medium as the diluent. It was hoped that by 
avoiding the complex aqueous chemistry of $\left[(\mathrm{CO})_{3} \mathrm{Tc}\left(\mathrm{H}_{2} \mathrm{O}\right)_{3}\right]^{+}$as described above, a more convenient pathway to a stable $\left[\mathrm{Tc}(\mathrm{CO})_{3} \mathrm{Cl}_{3}\right]^{2-}$ precursor could be developed in which large quantities of a precursor to the aqua complex $\left[\mathrm{Tc}(\mathrm{CO})_{3}\left(\mathrm{H}_{2} \mathrm{O}\right)_{3}\right]^{+}$would be readily prepared. One such approach involves a preparation reported by Alberto et al. (1998c) and involves reduction of Tc(VII) to Tc(I) by borohydride in the form of a tetrahydrofuran (THF)- $\mathrm{BH}_{3}$ complex in the presence of $\mathrm{CO}$ as described by reaction 2 .

$$
\mathrm{TcO}_{4}^{-}+3 \mathrm{Cl}-\frac{\mathrm{BH}_{3}, \mathrm{CO}}{\mathrm{THF}, \Delta} \quad\left[\mathrm{Tc}(\mathrm{CO})_{3} \mathrm{Cl}_{3}\right]^{2-}
$$

This $\left[\mathrm{TcCl}_{3}(\mathrm{CO})_{3}\right]^{2-}$ precursor is isolated and can be used to obtain our target $\left[\mathrm{Tc}(\mathrm{CO})_{3}\left(\mathrm{H}_{2} \mathrm{O}\right)_{3}\right]^{+}$product by the simple exchange reaction 3 .

$$
\left[\mathrm{Tc}(\mathrm{CO})_{3} \mathrm{Cl}_{3}\right]^{2-}+3 \mathrm{H}_{2} \mathrm{O} \quad \stackrel{\mathrm{H}_{2} \mathrm{O}}{\Delta} \quad\left[\mathrm{Tc}(\mathrm{CO})_{3}\left(\mathrm{H}_{2} \mathrm{O}\right)_{3}\right]^{+}+3 \mathrm{Cl}^{-}
$$

Synthesis 6. Three milliliters of $1-\mathrm{M} \mathrm{BH}_{3}$ solution in THF was added to $0.28 \mathrm{~g}$ of $\left[\mathrm{Bu}_{4} \mathrm{~N}\right] \mathrm{Cl}$ dissolved in $14 \mathrm{ml}$ of THF. CO was bubbled through the resulting solution for 10 minutes. The reaction flask then was placed in an ice bath. One milliliter of $16.5 \mathrm{mM} \mathrm{NH}_{4} \mathrm{TcO}_{4}$ stock solution mixed with $3 \mathrm{ml}$ of THF was added drop-wise to the $\mathrm{BH}_{3} /\left[\mathrm{Bu}_{4} \mathrm{~N}\right] \mathrm{Cl}$ solution over a period of 20 minutes. The color of the reaction solution turned from colorless to yellow and then to brown. $\mathrm{CO}$ flushing was continued for three hours at room temperature; the reaction solution remained brown. The reaction solution was divided into two portions and a 1-M HCl solution was added to one sample. No gas evolution was observed, suggesting that all the $\mathrm{BH}_{3}$ was consumed prior to this $\mathrm{HCl}$ addition. To each sample, $\left.0.14 \mathrm{~g}^{2} \mathrm{Et}_{4} \mathrm{~N}\right] \mathrm{Cl}$ was added and the solution was left stirring overnight to crystallize any expected $\left[\mathrm{Et}_{4} \mathrm{~N}\right]_{2}\left[\mathrm{Tc}(\mathrm{CO})_{3} \mathrm{Cl}_{3}\right]$ product. No precipitate was formed.

Synthesis 7. Two major modifications to the Synthesis 6 approach were made. First, the aqueous $\mathrm{NH}_{4} \mathrm{TcO}_{4}$ solution was substituted with a solution of $\left[\mathrm{Bu}_{4} \mathrm{~N}\right] \mathrm{TcO}_{4}$ in THF. It was prepared by dissolution of $0.7 \mathrm{~g}$ of solid $\left[\mathrm{Bu}_{4} \mathrm{~N}\right] \mathrm{Cl}$ in water to which $1 \mathrm{ml}$ of $16.5 \mathrm{mM} \mathrm{NH}_{4} \mathrm{TcO}_{4}$ stock solution was slowly added. The resulting $\left[\mathrm{Bu}_{4} \mathrm{~N}\right] \mathrm{TcO}_{4}$ precipitate was separated by decantation, air-dried overnight, and dissolved in $3 \mathrm{ml}$ of THF. Second, the amount of $\mathrm{BH}_{3}$ reductant was significantly increased. Seven milliliters of a $1-\mathrm{M} \mathrm{BH}_{3}$ solution in THF was added to $0.28 \mathrm{~g}$ of $\left[\mathrm{Bu}_{4} \mathrm{~N}\right] \mathrm{Cl}$ dissolved in $14 \mathrm{ml}$ of THF. CO was bubbled through the resulting solution for 10 minutes. The reaction flask then was placed in the ice bath. The solution of $\left[\mathrm{Bu}_{4} \mathrm{~N}\right] \mathrm{TcO}_{4}$ in THF was added drop-wise. The reaction mixture changed to yellow and then back to colorless during the addition of the first several incremental additions, then the yellow color persisted. An additional about $30 \mathrm{ml}$ of a $1 \mathrm{M} \mathrm{BH}_{3}$ solution in THF was added until the yellow color disappeared. Flushing the reaction vessel with carbon monoxide was continued for 3 hours at room temperature. During this time the reaction mixture turned brown.

The reaction mixture was divided into two portions. A $1 \mathrm{M} \mathrm{HCl}$ solution was added to one sample; no gas evolution was observed, suggesting that all $\mathrm{BH}_{3}$ was consumed prior to the $\mathrm{HCl}$ addition. To each sample, $0.14 \mathrm{~g}\left[\mathrm{Et}_{4} \mathrm{~N}\right] \mathrm{Cl}$ was added and left stirring overnight to crystallize any expected $\left[\mathrm{Et}_{4} \mathrm{~N}\right]_{2}\left[\mathrm{Tc}(\mathrm{CO})_{3} \mathrm{Cl}_{3}\right]$ product. A small amount of white precipitate was formed. Fourier Transfer Infrared (FTIR) spectra (Figure 2.1) of the remaining solution showed the presence of the targeted product as based on its characteristic CO bands at 1930 and $2030 \mathrm{~cm}^{-1}$, attributed to the symmetric carbonyl stretch, 
and at 1721 and $1763 \mathrm{~cm}^{-1}$, assigned to the asymmetric carbonyl stretch (Takayama et al. 2005). The solid fraction exhibited a nearly identical FTIR profile (Figure 2.1).

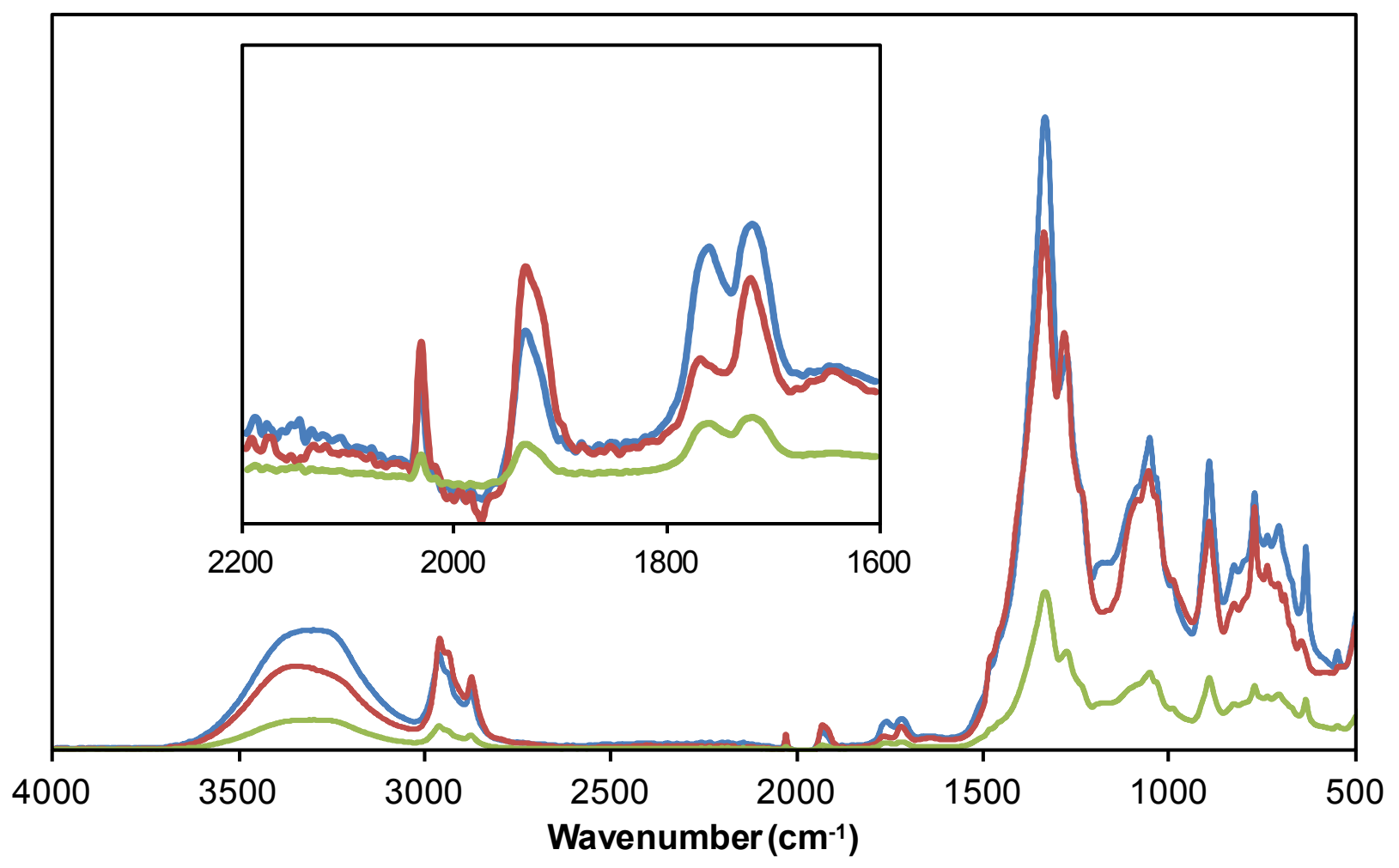

Figure 2.1. FTIR Spectra of the Liquid Reaction Mixtures from Synthesis 7 (green trace) and Synthesis 8 (blue trace) and of the Solid Generated from the Reaction Mixture from Synthesis 7 (red trace) that Contain $\left[\mathrm{Tc}(\mathrm{CO})_{3} \mathrm{Cl}_{3}\right]^{2-}$ Product. The inset shows the symmetric (at 1930 and $2030 \mathrm{~cm}^{-1}$ ) and asymmetric (at 1763 and $1721 \mathrm{~cm}^{-1}$ ) $\mathrm{C}=\mathrm{O}$ stretching modes.

Synthesis 8. Synthesis 7 was repeated with the following changes: the total amount of 1-M $\mathrm{BH}_{3}$ reductant in THF was increased to $60 \mathrm{ml}$. The reaction mixture was kept under CO atmosphere at about $60^{\circ} \mathrm{C}$ for three days, until its color turned from yellow/brown to colorless. Addition of $\left[\mathrm{Et}_{4} \mathrm{~N}\right] \mathrm{Cl}$ crystallized a small amount of the final product. This synthesis was repeated four times with consistent results. FTIR spectra of the liquid phases demonstrated the presence of Tc-CO bands identical to those observed in the product of Synthesis 7 (Figure 2.1). The amount of crystallized $\left[\mathrm{Et}_{4} \mathrm{~N}\right]_{2}\left[\mathrm{Tc}(\mathrm{CO})_{3} \mathrm{Cl}_{3}\right]$ product in this procedure was too small to convert to the target $\left[\mathrm{Tc}(\mathrm{CO})_{3}\left(\mathrm{H}_{2} \mathrm{O}\right)_{3}\right]^{+}$material and conduct any NMR characterization; therefore, the liquid reaction product containing $\left[\mathrm{Et}_{4} \mathrm{~N}\right]_{2}\left[\mathrm{Tc}(\mathrm{CO})_{3} \mathrm{Cl}_{3}\right]$ was used for subsequent study.

\subsection{5 $\quad{ }^{99}$ Tc NMR Characterization of the THF Reaction Product}

The THF mixture containing $\left[\mathrm{TcCl}_{3}(\mathrm{CO})_{3}\right]^{2-}$ reaction product was mixed with water in a 1:1 ratio and heated at about $60^{\circ} \mathrm{C}$ for three hours. After heating, the solution $\mathrm{pH}$ was incrementally adjusted using $\mathrm{HCl}$ or $\mathrm{NaOH}$ (note: the absolute $\mathrm{pH}$ value could not be obtained due to the presence of THF in the 
solution; therefore, the $\mathrm{pH}$ was increased relative to the initial acidic value). To the resulting solutions $\mathrm{D}_{2} \mathrm{O}$ was added in a 3:1 $\mathrm{D}_{2} \mathrm{O}$ to $\mathrm{H}_{2} \mathrm{O}$ ratio and ${ }^{99} \mathrm{Tc}-\mathrm{NMR}$ spectra were collected. The results of the NMR analysis are reported in Table 2.2 .

Table 2.2. ${ }^{99} \mathrm{Tc}-\mathrm{NMR}$ Characterization of the THF Reaction Product from Synthesis 8

\begin{tabular}{|c|c|c|c|c|}
\hline \multirow[b]{2}{*}{ Solution Preparation } & \multicolumn{3}{|c|}{${ }^{99}$ Tc Resonance } & \multirow[b]{2}{*}{ Assignment $^{\text {a) }}$} \\
\hline & $\begin{array}{l}\text { Chemical Shift, } \\
\text { ppm }\end{array}$ & $\begin{array}{l}\text { Half-width, } \\
\mathrm{Hz}\end{array}$ & Integration & \\
\hline $\begin{array}{c}\text { Original Reaction } \\
\text { Mixture }\end{array}$ & $\begin{array}{c}0 \\
-866 \\
-905\end{array}$ & $\begin{array}{l}70 \\
70\end{array}$ & $\begin{array}{c}0.2 \\
1.0 \\
0.01\end{array}$ & $\begin{array}{c}\mathrm{TcO}_{4}^{-} \\
{\left[\mathrm{Tc}(\mathrm{CO})_{3}\left(\mathrm{H}_{2} \mathrm{O}\right)_{3}\right]^{+}} \\
{\left[\mathrm{Tc}(\mathrm{CO})_{4}\left(\mathrm{H}_{2} \mathrm{O}\right)_{2}\right]^{+}}\end{array}$ \\
\hline $\begin{array}{l}\text { Rxn. Mixture Warmed } \\
\text { with Water, } \mathrm{pH}=3\end{array}$ & $\begin{array}{c}0 \\
-866\end{array}$ & 60 & $\begin{array}{c}0.15 \\
1.0\end{array}$ & $\begin{array}{c}\mathrm{TcO}_{4}^{-} \\
{\left[\mathrm{Tc}(\mathrm{CO})_{3}\left(\mathrm{H}_{2} \mathrm{O}\right)_{3}\right]^{+}}\end{array}$ \\
\hline $\begin{array}{c}\text { Rxn. Mixture Warmed } \\
\text { with Water, } \mathrm{pH}=5\end{array}$ & $\begin{array}{c}0 \\
-866 \\
-892 \\
-904\end{array}$ & $\begin{array}{l}60 \\
90 \\
60\end{array}$ & $\begin{array}{c}0.2 \\
1.0 \\
1.0 \\
0.02\end{array}$ & $\begin{array}{c}\mathrm{TcO}_{4}^{-} \\
{\left[\mathrm{Tc}(\mathrm{CO})_{3}\left(\mathrm{H}_{2} \mathrm{O}\right)_{3}\right]^{+}} \\
{\left[\mathrm{Tc}(\mathrm{CO})_{3} \mathrm{Cl}_{3}\right]^{2-}} \\
{\left[\mathrm{Tc}(\mathrm{CO})_{4}\left(\mathrm{H}_{2} \mathrm{O}\right)_{2}\right]^{+}}\end{array}$ \\
\hline $\begin{array}{l}\text { Rxn. Mixture Warmed } \\
\text { with Water, } \mathrm{pH}=7\end{array}$ & $\begin{array}{c}0 \\
-867 \\
-953 \\
-1056\end{array}$ & $\begin{array}{c}70 \\
65 \\
100\end{array}$ & $\begin{array}{l}0.1 \\
1.0 \\
0.1 \\
0.2\end{array}$ & $\begin{array}{c}\mathrm{TcO}_{4}^{-} \\
{\left[\mathrm{Tc}(\mathrm{CO})_{3}\left(\mathrm{H}_{2} \mathrm{O}\right)_{3}\right]^{+}} \\
{\left[\mathrm{Tc}(\mathrm{CO})_{3} \mathrm{Cl}_{2}\right]^{-}} \\
{\left[\mathrm{Tc}(\mathrm{CO})_{3}(\mathrm{OH})\left(\mathrm{H}_{2} \mathrm{O}\right)_{2}\right]}\end{array}$ \\
\hline $\begin{array}{l}\text { Rxn. Mixture Warmed } \\
\text { with Water, } \mathrm{pH}=12\end{array}$ & -1057 & 100 & 1.0 & {$\left[\mathrm{Tc}(\mathrm{CO})_{3}(\mathrm{OH})\left(\mathrm{H}_{2} \mathrm{O}\right)_{2}\right]$} \\
\hline
\end{tabular}

\subsubsection{Diglyme Synthesis of $\mathrm{fac}-\mathrm{Tc}(\mathrm{CO})_{3}{ }^{+}$}

Even though the synthetic route based on the reduction of Tc(VII) to Tc(I) in THF solvent (Syntheses 6 through 8) produced the target product, two challenges have been observed: 1) insufficient conversion leading to the presence of unreacted $\mathrm{TcO}_{4}{ }^{-}$upon completion of the synthesis, and 2) a difficult purification procedure. In an attempt to overcome these shortcomings, a different synthetic approach to obtaining the $\left[\mathrm{Tc}(\mathrm{CO})_{3} \mathrm{Cl}_{3}\right]^{2-}$ precursor of the desired $\left[\mathrm{Tc}(\mathrm{CO})_{3}\left(\mathrm{H}_{2} \mathrm{O}\right)_{3}\right]^{+}$product was investigated. This new approach, based on one of the first reported syntheses of $\left[\mathrm{Tc}(\mathrm{CO})_{3} \mathrm{Cl}_{3}\right]^{2-}$ (Alberto et al. 1995), involves a two-step reduction of $\mathrm{Tc}(\mathrm{VII})$ to $\mathrm{Tc}(\mathrm{I})$. In the first step, $\mathrm{TcO}_{4}{ }^{-}$is reduced to $\mathrm{Tc}(\mathrm{V})$ in the form of stable compound $\left[\mathrm{Bu}_{4} \mathrm{~N}\right]\left[\mathrm{TcOCl}_{4}\right]$ (see Reaction 4 ), which can be easily isolated. This should provide a more stable $\mathrm{Tc}(\mathrm{V})$ source than the typically unstable $\mathrm{Tc}(\mathrm{V})$ formed in situ.

$$
\mathrm{TcO}_{4}^{-}+\left[\mathrm{Bu}_{4} \mathrm{~N}\right] \mathrm{Cl} \stackrel{12 \mathrm{~N} \mathrm{HCl}}{\longrightarrow} \quad\left[\mathrm{Bu}_{4} \mathrm{~N}\right]\left[\mathrm{TcOCl}_{4}\right]+\mathrm{Cl}+3 \mathrm{H}_{2} \mathrm{O}+\mathrm{Cl}_{2}
$$

The second reduction step from $\mathrm{Tc}(\mathrm{V})$ to $\mathrm{Tc}(\mathrm{I})$ is described by Reaction 5:

$\left[\mathrm{Bu}_{4} \mathrm{~N}\right]\left[\mathrm{TcOCl}_{4}\right]$

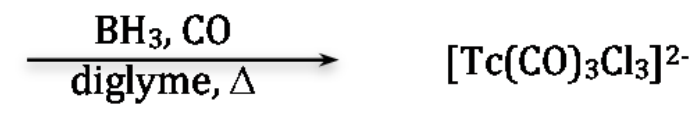


Note that the boiling point of diglyme is $162^{\circ} \mathrm{C}$, so the reaction mixture can be safely heated to a higher temperature, typically $110-120^{\circ} \mathrm{C}$ than can be done with THF. This $\left[\mathrm{Tc}(\mathrm{CO})_{3} \mathrm{Cl}_{3}\right]^{2-}$ precursor can then be converted to $\left[\mathrm{Tc}(\mathrm{CO})_{3}\left(\mathrm{H}_{2} \mathrm{O}\right)_{3}\right]^{+}$product by the exchange reaction 3 .

\subsubsection{Synthesis 9}

Step 1. $100 \mathrm{mg}$ of $\mathrm{NH}_{4} \mathrm{TcO}_{4}$ was dissolved in $4 \mathrm{ml}$ water $(0.500 \mathrm{mMol})$ and slowly added to $40 \mathrm{ml}$ of concentrated $\mathrm{HCl}$ solution stirred in a beaker. The solution turned yellow-green. After 10 minutes, $128 \mathrm{mg}$ of $\mathrm{Bu}_{4} \mathrm{NCl}$ dissolved in $4 \mathrm{ml}$ water was added, producing a light green precipitate. The precipitate was filtered and heated in a flask overnight at $40^{\circ} \mathrm{C}$ to dry off the $\mathrm{HCl}$ and any residual water.

Step 2. The green-brown precipitate generated in Step 1 was dissolved in $20 \mathrm{ml}$ of diglyme to produce a yellow-brown solution (Figure 2.2). $\mathrm{CO}$ was passed through the solution for 30 minutes. Three milliliters of 1-M BH $3 /$ THF was added drop-wise over 5 minutes, resulting in a dirty brown solution. It was heated to $110^{\circ} \mathrm{C}$ under $\mathrm{CO}$ atmosphere. After five hours, the solution was cooled to room temperature and $2 \mathrm{ml}$ more $\mathrm{BH}_{3}$-THF were added. The solution evolved gas and a further $3 \mathrm{ml}$ of $\mathrm{BH}_{3}-\mathrm{THF}$ were added until no more fumes were observed following borane addition. Subsequently, the solution was heated to $110^{\circ} \mathrm{C}$ overnight under constant $\mathrm{CO}$ bubbling.
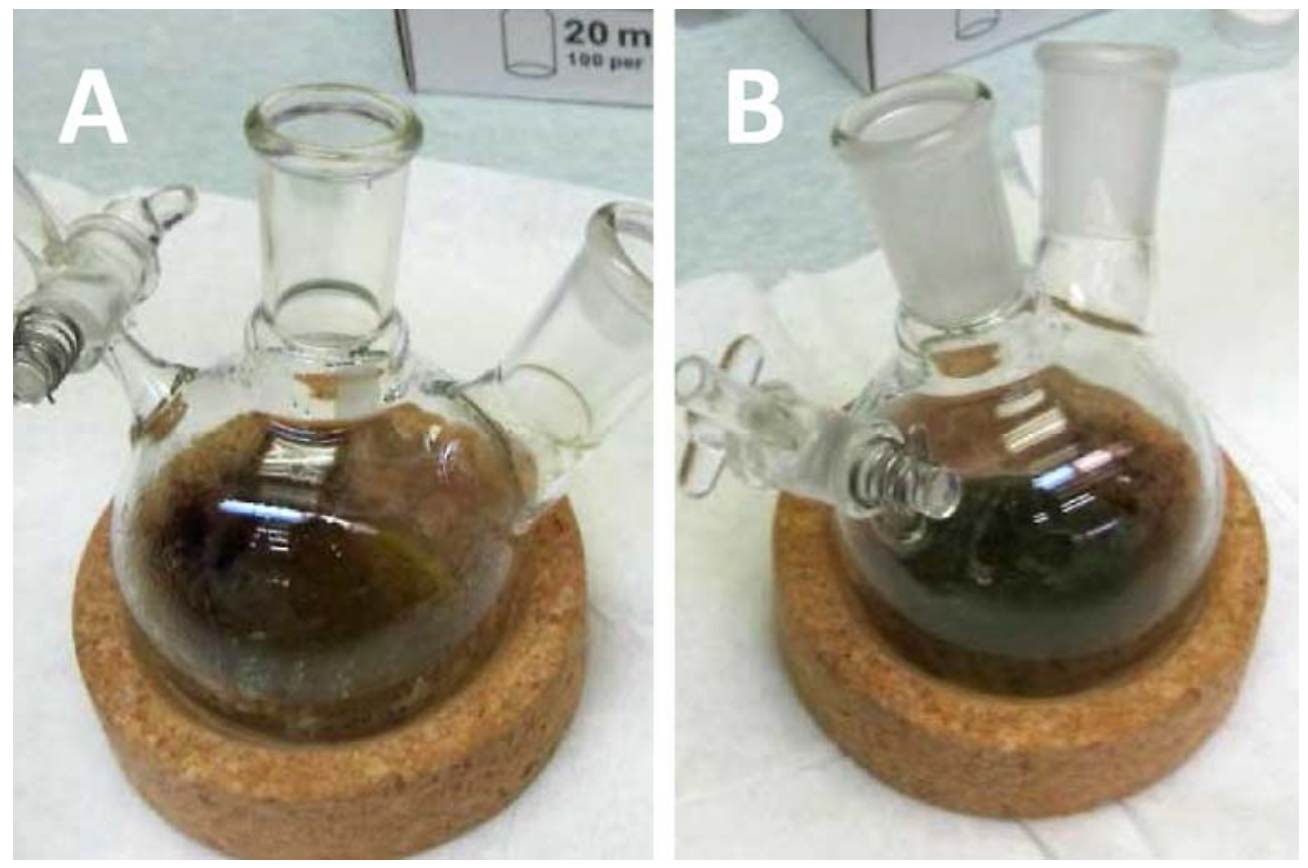

Figure 2.2. (A) Yellow-brown Solution Formed After Dissolving $\left(\mathrm{Bu}_{4} \mathrm{~N}\right)\left[\mathrm{TcOCl}_{4}\right]$ in Diglyme in Step 2 of Synthesis 9; (B) Dark Brown Solution Resulting from Addition of $\mathrm{BH}_{3}$-THF Solution to $\left(\mathrm{Bu}_{4} \mathrm{~N}\right)\left[\mathrm{TcOCl}_{4}\right]$ in Diglyme

The following day, the dirty brown solution was cooled to room temperature and $360 \mathrm{mg} \mathrm{Bu} / \mathrm{NCl}$ $(1.3 \mathrm{mMol})$ were added and stirred for 1 hour. Filtration produced a dirty brown precipitate, presumably that of $\left(\mathrm{Bu}_{4} \mathrm{~N}\right)_{2} \mathrm{TcCl}_{6}$ (Figure 2.2). The precipitate was washed with $2 \times 10 \mathrm{ml}$ diglyme. The combined filtrate and wash solutions were put in a clean, dry flask, $0.680 \mathrm{mg}$ of $\mathrm{Et}_{4} \mathrm{NCl}$ was added, and the solution was warmed to $60^{\circ} \mathrm{C}$ overnight. A white-green precipitate settled in the flask (Figure 2.3). The 
precipitate was collected and dried, then dissolved in $3 \mathrm{ml} \mathrm{H}_{2} \mathrm{O}$ and warmed for two hours. ${ }^{99} \mathrm{Tc}-\mathrm{NMR}$ spectrum of the solution was recorded in $\mathrm{D}_{2} \mathrm{O}$ and showed very little presence of the desired $\left[\mathrm{Tc}(\mathrm{CO})_{3}\left(\mathrm{H}_{2} \mathrm{O}\right)_{3}\right]^{+}$product at about $-865 \mathrm{ppm}$; therefore, a modified procedure was attempted.
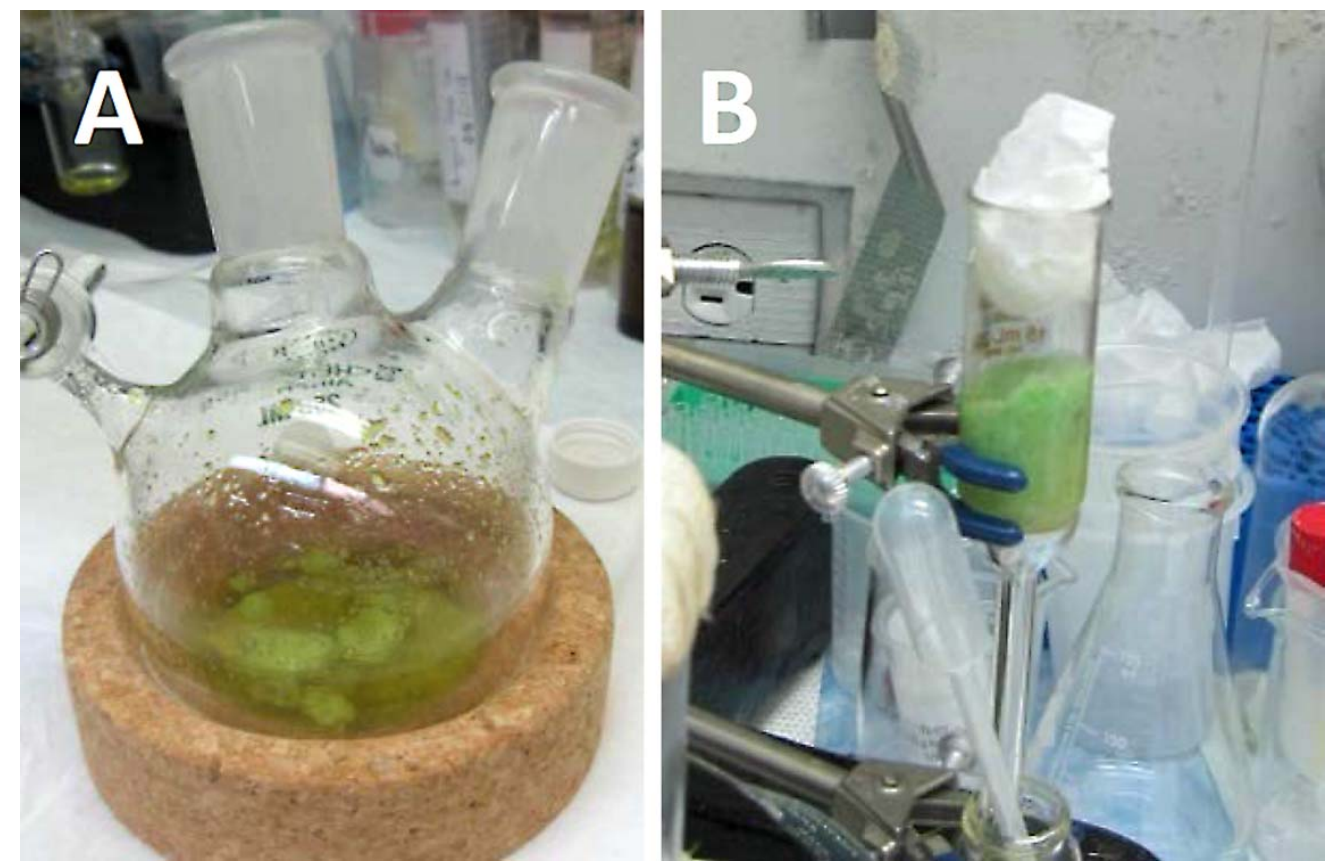

Figure 2.3. (A) White-green Precipitate Formed After Warming the Reaction Mixture of Synthesis 9 with $\mathrm{Et}_{4} \mathrm{NCl}$ Overnight at $60^{\circ} \mathrm{C}$; (B) the White-green Precipitate

The low yield of this synthesis is attributed to the insufficient precipitation of the $\mathrm{Bu}_{4} \mathrm{~N}\left[\mathrm{TcOCl}_{4}\right]$ product of Step 1 as well as presumable presence of residual $\mathrm{HCl}$ in the starting material, which, in a competing side reaction, reacts irreversibly with the $\mathrm{BH}_{3}$ reductant; thus, a modified procedure was attempted.

\subsubsection{Synthesis 10}

Step 1. Powdered solid $\mathrm{NH}_{4} \mathrm{TcO}_{4}(300 \mathrm{mg}, 1.66 \mathrm{mMol})$ was dissolved in $4 \mathrm{ml}$ of distilled water. The resultant solution was slowly added to $40 \mathrm{ml}$ of concentrated $\mathrm{HCl}$ solution stirred in a beaker. Within 10 minutes, the color of the solution turned from yellow to green. After another 15 minutes, $4 \mathrm{ml}$ of $75 \%$ $\mathrm{w} / \mathrm{w} \mathrm{Bu}{ }_{4} \mathrm{NCl}$ in water was added to the green solution drop-wise. This resulted in the formation of micro-crystalline green precipitate. The precipitate was centrifuged and collected by filtration. The solid was allowed to air dry at room temperature. Once dry, the solid was dissolved in isopropanol and allowed to crystallize by slow evaporation. The $\left[\mathrm{Bu}_{4} \mathrm{~N}\right]\left[\mathrm{TcOCl}_{4}\right]$ crystals were collected by gravity filtration through a glass-frit and air dried for subsequent use. The product was dissolved in deuterated acetonitrile and characterized by ${ }^{99} \mathrm{Tc}$ NMR (Table 2.3 ). The resulting spectrum showed only a very small pertechnetate signal. It is assumed that the $\mathrm{Tc}(\mathrm{V})$ resonance of the $\left[\mathrm{TcOCl}_{4}\right]^{-}$species is very broad and therefore could not be observed. When the $\left[\mathrm{Bu}_{4} \mathrm{~N}\right]\left[\mathrm{TcOCl}_{4}\right]$ material was dissolved in $\mathrm{D}_{2} \mathrm{O}$, its color immediately converted from bright green to dark brown, presumably due to a disproportionation reaction, with generation of $\mathrm{Tc}(\mathrm{IV})$ in the form of $\mathrm{TcO}_{2}$ and $\mathrm{Tc}(\mathrm{VII})$ as $\mathrm{TcO}_{4}{ }^{-} \cdot{ }^{99} \mathrm{Tc} \mathrm{NMR}$ confirmed that the corresponding sample contained a very strong $\mathrm{TcO}_{4}{ }^{-}$signal. 
Step 2. Twenty milliliters of diglyme was added to $50 \mathrm{mg}(0.1 \mathrm{mMol})$ of green crystalline blocks of $\left[\mathrm{Bu}_{4} \mathrm{~N}\right]\left[\mathrm{TcOCl}_{4}\right]$ to produce a green solution (Figure 2.4A). CO was bubbled through the solution for 1 hour. Subsequently, $15 \mathrm{ml}$ of $1-\mathrm{M} \mathrm{BH}_{3}$-THF was added drop-wise over a period of 5 minutes, which resulted in a dark brown solution. The reaction mixture was heated to $110^{\circ} \mathrm{C}$ under the $\mathrm{CO}$ atmosphere. After five hours, the solution turned pale brown (Figure 2.4B). CO was bubbled through it overnight at $110^{\circ} \mathrm{C}$. By the next day, the solution had turned yellow (Figure $2.4 \mathrm{C}$ ). It was cooled to room temperature and $360 \mathrm{mg}(1.3 \mathrm{mMol})\left[\mathrm{Bu}_{4} \mathrm{~N}\right] \mathrm{Cl}$ was added. The mixture was stirred for 1 hour. Fluffy yellowish precipitate of $\left[\mathrm{Bu}_{4} \mathrm{~N}\right]_{2}\left[\mathrm{TcCl}_{6}\right]$ was formed, which was filtered and the filtrate transferred to a clean flask. To the filtrate $0.680 \mathrm{mg}(2.17 \mathrm{mMol})$ of $\left[\mathrm{Et}_{4} \mathrm{~N}\right] \mathrm{Cl}$ was added and the solution warmed to $60^{\circ} \mathrm{C}$ overnight. A white precipitate formed and was filtered out for analysis by FTIR (Figure 2.5). The FTIR spectrum was nearly identical to the spectrum of $\left[\mathrm{Et}_{4} \mathrm{~N}\right]_{2}\left[\mathrm{Tc}(\mathrm{CO})_{3} \mathrm{Cl}_{3}\right]$ product obtained in Syntheses 7 and 8 (Figure 2.1), confirming the presence of the carbonyl product. $\mathrm{A}^{99} \mathrm{Tc}-\mathrm{NMR}$ spectrum of the precipitate dissolved in $\mathrm{CD}_{3} \mathrm{CN}$ was collected (Figure 2.6). The NMR spectrum shows a sharp resonance at $-1140 \mathrm{ppm}$ denoting the presence of the $\left[\mathrm{Tc}(\mathrm{CO})_{3} \mathrm{Cl}_{3}\right]^{2-}$ species. An additional sharp resonance at $-1117 \mathrm{ppm}$ is speculatively assigned to the $\left[\mathrm{Tc}(\mathrm{CO})_{3} \mathrm{Cl}_{2}\right]^{-}$species. A broad resonance that appeared at -597 ppm was not identified.
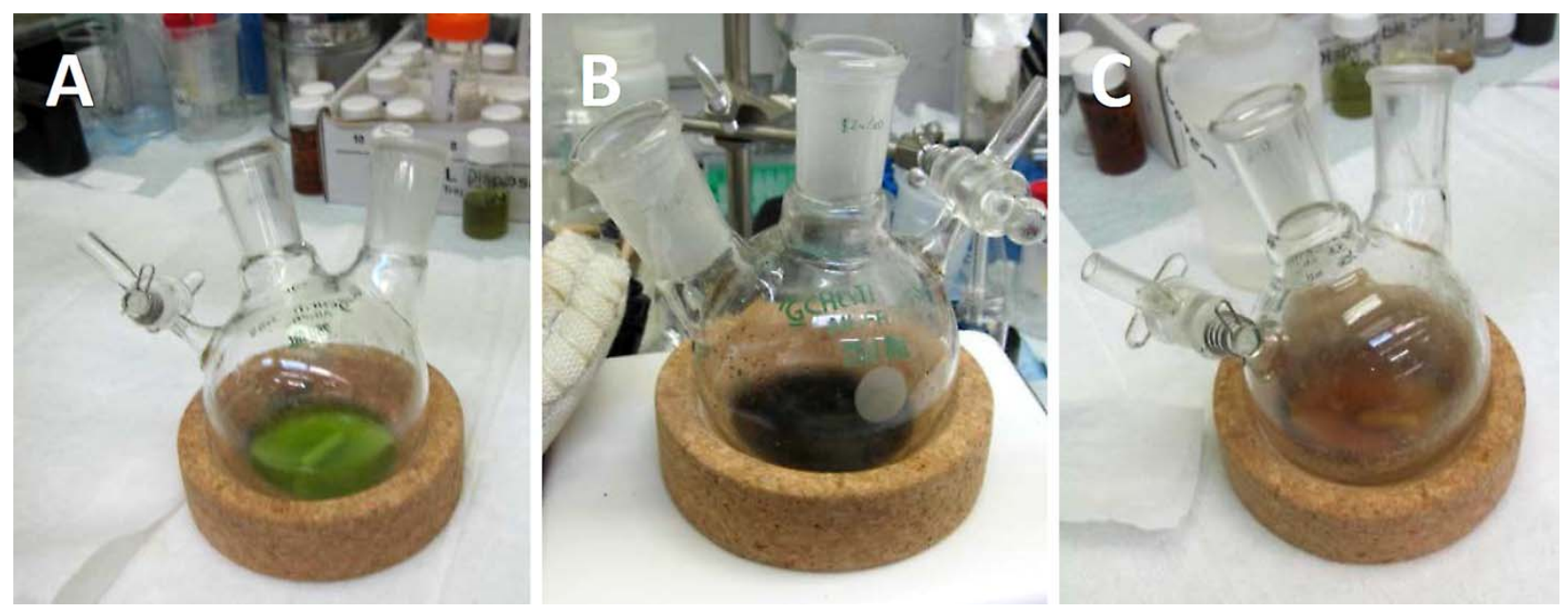

Figure 2.4. (A) Green Solution Formed After Dissolving $\left(\mathrm{Bu}_{4} \mathrm{~N}\right)\left[\mathrm{TcOCl}_{4}\right]$ in Diglyme in Step 2 of Synthesis 10; (B) Dark Brown Solution Resulting from Addition of $\mathrm{BH}_{3}$-THF Solution to $\left(\mathrm{Bu}_{4} \mathrm{~N}\right)\left[\mathrm{TcOCl}_{4}\right]$ in Diglyme; (C) Yellow Solution Generated After Heating the Reaction Mixture at $110^{\circ} \mathrm{C}$ Overnight 


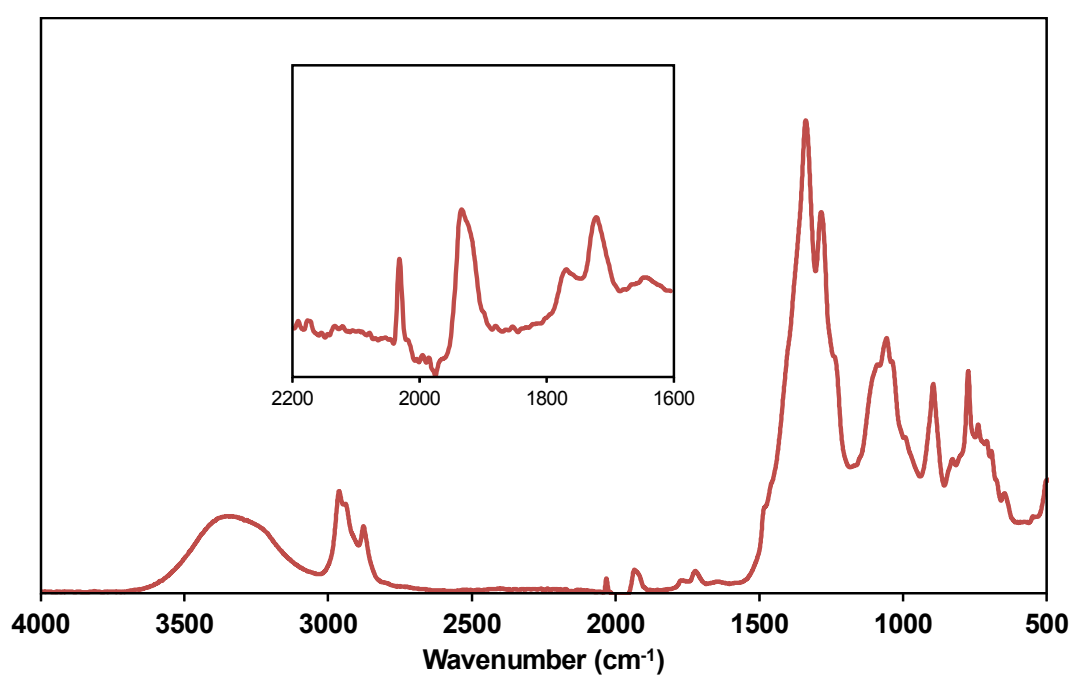

Figure 2.5. Infrared Spectrum of White Solid Generated from Synthesis 10. Inset shows symmetric (1935 and $\left.2030 \mathrm{~cm}^{-1}\right)$ and asymmetric $\left(1765\right.$ and $\left.1714 \mathrm{~cm}^{-1}\right) \mathrm{C}=\mathrm{O}$ stretching modes.

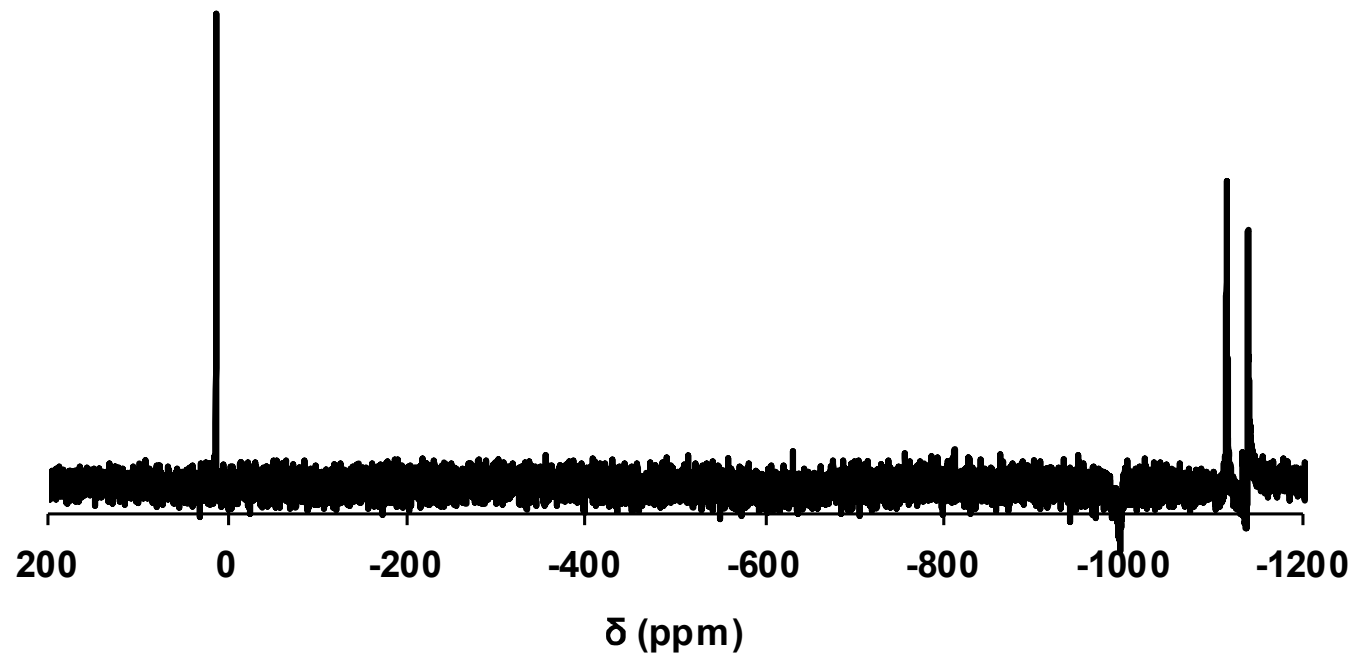

Figure 2.6. ${ }^{99}$ Tc-NMR Spectrum of the White Precipitate Obtained in Synthesis 10 Recorded in $\mathrm{CD}_{3} \mathrm{CN}$. The spectrum shows a resonance at $-1117 \mathrm{ppm}$ corresponding to the $\left[\mathrm{Tc}(\mathrm{CO})_{3} \mathrm{Cl}_{2}\right]^{-}$species and one at $-1140 \mathrm{ppm}$ corresponding to the $\left[\mathrm{Tc}(\mathrm{CO})_{3} \mathrm{Cl}_{3}\right]^{2-}$ species, along with a strong $\mathrm{TcO}_{4}^{-}$signal at $5 \mathrm{ppm}$. 
Table 2.3. ${ }^{99}$ Tc-NMR Characterization of the Reaction Mixture Generated in Synthesis 10

\begin{tabular}{|c|c|c|c|c|}
\hline Solution Description & $\begin{array}{c}\text { Chemical Shift } \\
\text { of }{ }^{99} \mathrm{Tc} \\
\text { Resonance, ppm }\end{array}$ & $\begin{array}{l}\text { Half-width of } \\
{ }^{99} \mathrm{Tc} \\
\text { Resonance, } \mathrm{Hz}\end{array}$ & Integration & Assignment \\
\hline $\begin{array}{c}\mathrm{Bu}_{4} \mathrm{~N} \mathrm{TcOCl} \\
\text { Solvent: } \mathrm{CD}_{3} \mathrm{CN}\end{array}$ & 2.6 (weak signal) & 40 & & $\mathrm{TcO}_{4}^{-}$ \\
\hline $\begin{array}{l}\mathrm{Bu}_{4} \mathrm{~N} \mathrm{TcOCl} \\
\text { Solvent: } \mathrm{D}_{2} \mathrm{O}\end{array}$ & $\begin{array}{l}3.0 \text { (very strong } \\
\text { signal) }\end{array}$ & 40 & & $\mathrm{TcO}_{4}^{-}$ \\
\hline $\begin{array}{l}\text { Reaction Product } \\
\text { Dissolved in } \mathrm{CD}_{3} \mathrm{CN}\end{array}$ & $\begin{array}{c}5 \\
-1117 \\
-1140\end{array}$ & $\begin{array}{c}70 \\
70 \\
100\end{array}$ & $\begin{array}{l}0.1 \\
1.0 \\
1.0\end{array}$ & $\begin{array}{c}\mathrm{TcO}_{4}^{-} \\
{\left[\mathrm{Tc}(\mathrm{CO})_{3} \mathrm{Cl}_{2}\right]^{-}} \\
{\left[\mathrm{Tc}(\mathrm{CO})_{3} \mathrm{Cl}_{3}\right]^{2-}}\end{array}$ \\
\hline $\begin{array}{c}\text { Reaction Product } \\
\text { Warmed with Water at } \\
\text { pH=2; Solvent: } \mathrm{D}_{2} \mathrm{O}\end{array}$ & $\begin{array}{c}1 \\
-865\end{array}$ & $\begin{array}{l}50 \\
80\end{array}$ & $\begin{array}{c}0.01 \\
1.0\end{array}$ & $\begin{array}{c}\mathrm{TcO}_{4}^{-} \\
{\left[\mathrm{Tc}(\mathrm{CO})_{3}\left(\mathrm{H}_{2} \mathrm{O}\right)_{3}\right]^{+}}\end{array}$ \\
\hline $\begin{array}{l}\text { Reaction Product } \\
\text { Dissolved in } 1 \mathrm{M} \mathrm{NaOH} \text {; } \\
\text { Solvent: } \mathrm{D}_{2} \mathrm{O}\end{array}$ & $\begin{array}{c}3 \\
-622 \\
-1062\end{array}$ & $\begin{array}{c}40 \\
\text { Broad } \\
100\end{array}$ & $\begin{array}{l}0.55 \\
0.65 \\
1.00\end{array}$ & $\begin{array}{c}\mathrm{TcO}_{4}^{-} \\
? \\
{\left[\mathrm{Tc}(\mathrm{CO})_{3}(\mathrm{OH})\left(\mathrm{H}_{2} \mathrm{O}\right)_{2}\right]}\end{array}$ \\
\hline
\end{tabular}

Synthesis 10 was repeated with minor modifications to obtain more precise information on the yield.

\subsubsection{Synthesis 11}

Step 1. The crystalline product, obtained as described in Synthesis 10 Step 1, was extensively washed with diethyl ether and left to dry overnight.

Step 2. One gram $(2 \mathrm{mMol})$ of ether-washed $\left[\mathrm{Bu}_{4} \mathrm{~N}\right]\left[\mathrm{TcOCl}_{4}\right]$ was dissolved in $25 \mathrm{ml}$ of diglyme to yield a bright green solution. The solution was analyzed by liquid scintillation counting. The ${ }^{99} \mathrm{Tc}$ concentration was $2.49 \mathrm{mg} / \mathrm{ml}$. Total ${ }^{99} \mathrm{Tc}$ was $62.3 \mathrm{mg}$, which corresponds to $315 \mathrm{mg}$ of $\left[\mathrm{Bu}_{4} \mathrm{~N}\right]\left[\mathrm{TcOCl}_{4}\right]$ $(\mathrm{MW}=500)$ present in 1 gram of the starting solid material.

$\mathrm{CO}$ was passed through the solution for 30 minutes and $10 \mathrm{ml}$ of $1-\mathrm{M} \mathrm{BH}_{3} / \mathrm{THF}$ was then added drop-wise over 2 minutes. An intense evolution of gas was observed. The color of the solution turned green-brown. Another $10 \mathrm{ml}$ of $\mathrm{BH}_{3}$-THF was added and the gas evolution stopped. The reaction flask was heated at $\sim 10^{\circ} \mathrm{C}$ for 5 hours while simultaneously passing $\mathrm{CO}$ though it. The solution color remained green-brown. The reaction mixture was cooled down and another $10 \mathrm{ml} \mathrm{BH}_{3}$-THF was added; no further gas evolution was observed. Following addition of the third 10-ml portion of borane-THF, the color of the solution turned yellow-light brown. The solution was heated at $90^{\circ} \mathrm{C}$ overnight.

The next morning heating was discontinued. The reaction mixture was intensely yellow and a small amount of colorless precipitate was present on the flask surface at the upper edge of solution. The ${ }^{99} \mathrm{Tc}$ concentration by liquid scintillation counting analysis was determined to be $1.71 \mathrm{mg} / \mathrm{ml}$. The volume of the reaction mixture was $37 \mathrm{ml}$ and the total amount of ${ }^{99} \mathrm{Tc}$ was $63.4 \mathrm{mg}$. Recovery was $101.8 \%$.

Five-hundred milligrams $(1.8 \mathrm{mMol})$ of $\left[\mathrm{Bu}_{4} \mathrm{~N}\right] \mathrm{Cl}$ was added to the warm solution and completely dissolved. The mixture was left overnight to precipitate any generated $\left[\mathrm{Bu}_{4} \mathrm{~N}\right]_{2}\left[\mathrm{TcCl}_{6}\right]$. The small amount of precipitate formed overnight was filtered out using a glass frit filter. The ${ }^{99} \mathrm{Tc}$ concentration in the filtrate $(37 \mathrm{ml})$ was $1.53 \mathrm{mg} / \mathrm{ml}$. The total amount of ${ }^{99} \mathrm{Tc}$ in the filtrate was $56.7 \mathrm{mg}(91 \%)$ and the total amount of ${ }^{99} \mathrm{Tc}$ in the $\left[\mathrm{Bu}_{4} \mathrm{~N}\right]_{2}\left[\mathrm{TcCl}_{6}\right]$ precipitate was $63.4-56.7=6.7 \mathrm{mg}$. 
To the filtrate, $500 \mathrm{mg}(3 \mathrm{mMol})\left[\mathrm{Et}_{4} \mathrm{~N}\right] \mathrm{Cl}$ was added to precipitate the desired reaction product $\left[\mathrm{Et}_{4} \mathrm{~N}\right]_{2}\left[\mathrm{Tc}(\mathrm{CO})_{3} \mathrm{Cl}_{3}\right]$. The solution was heated with constant stirring to $90^{\circ} \mathrm{C}$. After two hours an off-white precipitate formed. Heating and stirring were stopped and solution was left to stand over the weekend.

At this time, the off-white precipitate was filtered out using the glass frit filter. The yellow filtrate (30 ml) contained $1.20 \mathrm{mg} / \mathrm{ml}{ }^{99} \mathrm{Tc}$. The total amount of ${ }^{99} \mathrm{Tc}$ in the filtrate was therefore $35.8 \mathrm{mg}(57.5 \%$ of initial Tc present; $63.1 \%$ of Tc available at the beginning of this step). The total ${ }^{99} \mathrm{Tc}$ in the $\left[\mathrm{Et}_{4} \mathrm{~N}\right]_{2}\left[\mathrm{Tc}(\mathrm{CO})_{3} \mathrm{Cl}_{3}\right]$ precipitate was $56.7-35.8=20.9 \mathrm{mg}(33 \%$ based on $\mathrm{Tc})$.

The $\left[\mathrm{Et}_{4} \mathrm{~N}\right]_{2}\left[\mathrm{Tc}(\mathrm{CO})_{3} \mathrm{Cl}_{3}\right]$ precipitate was washed with $20 \mathrm{ml}$ of ether. The ${ }^{99} \mathrm{Tc}$ concentration found in the ether wash was $0.0885 \mathrm{mg} / \mathrm{ml}$. The total amount of ${ }^{99} \mathrm{Tc}$ in the ether wash was found to be $1.8 \mathrm{mg}$ and after washing the total amount was $20.9-1.8=19.1 \mathrm{mg}$. This mass corresponds to $106 \mathrm{mg}$ of $\left[\mathrm{Et}_{4} \mathrm{~N}\right]_{2}\left[\mathrm{Tc}(\mathrm{CO})_{3} \mathrm{Cl}_{3}\right](\mathrm{MW}=549.5)$ compound present in the precipitate. The product yield, based on precipitate analysis, was $(19.1 \mathrm{mg} / 62.3 \mathrm{mg}) \times 100 \%=30.5 \%$. However, ${ }^{99} \mathrm{Tc}-\mathrm{NMR}$ analysis revealed that a significant portion of non-crystallized product remained in the mother liquor.

The precipitate was left overnight to dry. The dry precipitate was weighed and yielded $0.83 \mathrm{~g}$, indicating that the $\left[\mathrm{Et}_{4} \mathrm{~N}\right]_{2}\left[\mathrm{Tc}(\mathrm{CO})_{3} \mathrm{Cl}_{3}\right](106 \mathrm{mg}$, see above) constituted $\sim 13.3 \%$ of the precipitate. The other components of the crystalline phase were presumably composed of a mixture of $\left[\mathrm{Et}_{4} \mathrm{~N}\right] \mathrm{Cl}$ and $\left[\mathrm{Bu}_{4} \mathrm{~N}\right] \mathrm{Cl}$; this presumption is supported by the FTIR spectrum of the solid material.

Thirty milligrams of the precipitate were dissolved in $3 \mathrm{ml}$ of DI water and the resulting solution's $\mathrm{pH}$ was adjusted to $\sim 1.5$ by the addition of $5 \mathrm{M} \mathrm{HCl}$. The sample was analyzed by ${ }^{99} \mathrm{Tc}$ NMR. The spectrum showed a large band at $-868 \mathrm{ppm}$, corresponding to $\left[\mathrm{Tc}(\mathrm{CO})_{3}\left(\mathrm{H}_{2} \mathrm{O}\right)_{3}\right]^{+}$, and a small band at $-902 \mathrm{ppm}$, which corresponds to $\mathrm{Tc}(\mathrm{CO})_{4}\left(\mathrm{H}_{2} \mathrm{O}\right)_{2}$. No $\mathrm{TcO}_{4}{ }^{-}$was found in the sample.

\subsection{Preliminary Speciation Analysis of $\left[\mathrm{Tc}(\mathrm{CO})_{3}\left(\mathrm{H}_{2} \mathrm{O}\right)_{3}\right]^{+}$}

Thirty milligrams of the $\left[\mathrm{Et}_{4} \mathrm{~N}\right]_{2}\left[\mathrm{Tc}(\mathrm{CO})_{3} \mathrm{Cl}_{3}\right]$-containing precipitate obtained in Synthesis 11 was dissolved in $3 \mathrm{ml}$ of DI water; the solution's $\mathrm{pH}$ was adjusted to $\sim 1.5$ by the addition of $5 \mathrm{M} \mathrm{HCl}$. The ${ }^{99} \mathrm{Tc}$ concentration in this solution was estimated to be $1.1 \mathrm{mM}$. In order to identify the buffer zone of $\left[\mathrm{Tc}(\mathrm{CO})_{3}\left(\mathrm{H}_{2} \mathrm{O}\right)_{3}\right]^{+}$, the solution $\mathrm{pH}$ was incrementally increased by the addition of $\mathrm{NaOH}$ and the ${ }^{99}$ Tc-NMR spectrum was recorded after each addition. Since the different Tc(I) tricarbonyl species exhibit characteristically distinct chemical shifts, ${ }^{99} \mathrm{Tc}$ NMR can be used as a convenient mode of Tc(I)-tricarbonyl speciation analysis. The observed results are displayed in Table 2.4 and Table 2.5, and Figure 2.7 and summarized below.

- $\mathrm{pH}$ range 1.15 to 6.6: All Tc(I) exists as $\left[\mathrm{Tc}(\mathrm{CO})_{3}\left(\mathrm{H}_{2} \mathrm{O}\right)_{3}\right]^{+}$.

- $\quad \mathrm{pH}$ of 4 and above: A small amount of pertechnetate appeared in the solution. Its concentration gradually increased, presumably due to oxidative decomposition of $\left[\mathrm{Tc}(\mathrm{CO})_{3}\left(\mathrm{H}_{2} \mathrm{O}\right)_{3}\right]^{+}$and/or its hydrolysis product.

- $\quad \mathrm{pH}$ range 6.8 to 7.4: The polynuclear tetrameric species $\left[\mathrm{Tc}(\mathrm{CO})_{3}(\mathrm{OH})_{4}\right.$, evidenced by the chemical shift at approximately $-586 \mathrm{ppm}$, appeared in the spectra. The concentration of $\left[\mathrm{Tc}(\mathrm{CO})_{3}(\mathrm{OH})\right]_{4}$ increased with increasing $\mathrm{pH}$, as evident from the integral values (see Table 2.4). Interestingly, the 
tetrameric species was observed at the lower $\mathrm{pH}$ prior to the appearance of the first hydrolysis product $\left[\mathrm{Tc}(\mathrm{CO})_{3}(\mathrm{OH})\left(\mathrm{H}_{2} \mathrm{O}\right)_{2}\right]$ itself, which suggests the greater stability of the tetrameric species.

- $\mathrm{pH}$ range 7.4 to 7.8: The generation of $\left[\mathrm{Tc}(\mathrm{CO})_{3}(\mathrm{OH})\left(\mathrm{H}_{2} \mathrm{O}\right)_{2}\right]$, evidenced by the observed chemical shift at about $-1056 \mathrm{ppm}$ is observed. The concentrations of $\left[\mathrm{Tc}(\mathrm{CO})_{3}(\mathrm{OH})\left(\mathrm{H}_{2} \mathrm{O}\right)_{2}\right]$ and $\left[\mathrm{Tc}(\mathrm{CO})_{3}(\mathrm{OH})\right]_{4}$ increased with $\mathrm{pH}$ while the concentration of $\left[\mathrm{Tc}(\mathrm{CO})_{3}\left(\mathrm{H}_{2} \mathrm{O}\right)_{3}\right]^{+}$decreased. Indeed, by a $\mathrm{pH}$ of 7.8 the concentration of $\left[\mathrm{Tc}(\mathrm{CO})_{3}(\mathrm{OH})\right]_{4}$ exceeded that of $\left[\mathrm{Tc}(\mathrm{CO})_{3}\left(\mathrm{H}_{2} \mathrm{O}\right)_{3}\right]^{+}$. The concentration ratio of total hydrolysis species $\left\{\left[\mathrm{Tc}(\mathrm{CO})_{3}(\mathrm{OH})\right]_{4}+\left[\mathrm{Tc}(\mathrm{CO})_{3}(\mathrm{OH})\left(\mathrm{H}_{2} \mathrm{O}\right)_{2}\right]\right\}$ to $\left[\mathrm{Tc}(\mathrm{CO})_{3}\left(\mathrm{H}_{2} \mathrm{O}\right)_{3}\right]^{+}$is $1.154: 1$.

- $\quad$ H 8.0: Sudden increase of $\left[\mathrm{Tc}(\mathrm{CO})_{3}(\mathrm{OH})\left(\mathrm{H}_{2} \mathrm{O}\right)_{2}\right]$ and decrease of $\left[\mathrm{Tc}(\mathrm{CO})_{3}(\mathrm{OH})\right]_{4}$ concentration such that their concentrations become comparable, suggesting conversion of the tetramer to $\left[\mathrm{Tc}(\mathrm{CO})_{3}(\mathrm{OH})\left(\mathrm{H}_{2} \mathrm{O}\right)_{2}\right]$. The concentration ratio of total hydrolysis species $\left\{\left[\mathrm{Tc}(\mathrm{CO})_{3}(\mathrm{OH})\right]_{4}+\right.$ $\left.\left[\mathrm{Tc}(\mathrm{CO})_{3}(\mathrm{OH})\left(\mathrm{H}_{2} \mathrm{O}\right)_{2}\right]\right\}$ to $\left[\mathrm{Tc}(\mathrm{CO})_{3}\left(\mathrm{H}_{2} \mathrm{O}\right)_{3}\right]^{+}$is $1.195: 1$, which corresponds to the $\mathrm{pH}$-consistent increase of the total products resulting from the first hydrolysis step.

- $\mathrm{pH}=14$ : In addition to pertechnetate, only $\left[\mathrm{Tc}(\mathrm{CO})_{3}(\mathrm{OH})\left(\mathrm{H}_{2} \mathrm{O}\right)_{2}\right]$ species was found in the spectrum, supporting the conclusion that the predominant existence of the tetramer species lies only in a limited, slightly alkaline $\mathrm{pH}$ range.

- In all spectra except the ones corresponding to a $\mathrm{pH}$ of 8 and 14 , the presence of the $\left[\mathrm{Tc}(\mathrm{CO})_{4}\left(\mathrm{H}_{2} \mathrm{O}\right)_{2}\right]^{+}$species at $\sim-905$ ppm is observed.

- No precipitate formation was observed throughout the titration experiment.

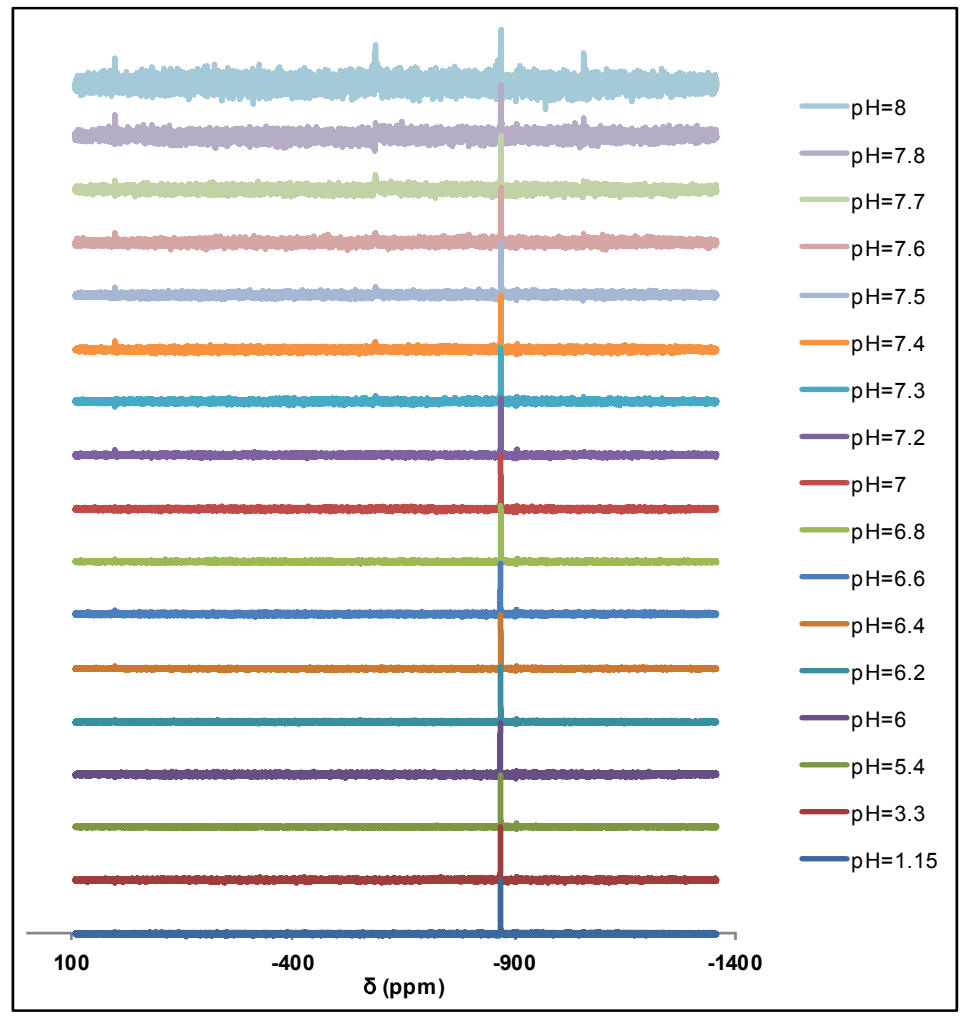

Figure 2.7. Speciation Analysis of $\left[\mathrm{Tc}(\mathrm{CO})_{3}\left(\mathrm{H}_{2} \mathrm{O}\right)_{3}\right]^{+}$as a Function of $\mathrm{pH}$ Using ${ }^{99} \mathrm{Tc}-\mathrm{NMR}$ Spectroscopy 
Table 2.4. Characterization of Speciation From $1 \mathrm{~b}$ as a pH Function Observed by ${ }^{99} \mathrm{Tc}-\mathrm{NMR}$ Spectroscopy. Band chemical shifts, half-width, and integration values normalized to $1 \mathrm{~b}$ unless otherwise noted.

\begin{tabular}{|c|c|c|c|c|}
\hline pH & $\begin{array}{c}\text { Chemical Shift of } \\
{ }^{99} \text { Te Resonance, } \\
\text { ppm }\end{array}$ & $\begin{array}{c}\text { Half-width of }{ }^{99} \mathrm{Tc} \\
\text { Resonance, } \mathrm{Hz}\end{array}$ & Integration & Volume of Solution, $\mathrm{ml}$ \\
\hline 1.15 & -868 & 80 & 1 & 4.00 \\
\hline $\mathbf{3 . 0}$ & $\begin{array}{l}-867 \\
-905\end{array}$ & $\begin{array}{l}70 \\
70\end{array}$ & $\begin{array}{c}1 \\
0.017\end{array}$ & 4.04 \\
\hline 4.0 & $\begin{array}{c}1 \\
-585 \\
-869\end{array}$ & $\begin{array}{c}40 \\
250 \\
70\end{array}$ & $\begin{array}{c}0.003 \\
0.0001 \\
0.988\end{array}$ & 4.07 \\
\hline $\mathbf{5 . 0}$ & $\begin{array}{c}-1 \\
-585 \\
-869\end{array}$ & $\begin{array}{c}40 \\
250 \\
70\end{array}$ & $\begin{array}{c}0.003 \\
0.0001 \\
0.988\end{array}$ & 4.09 \\
\hline 6.0 & $\begin{array}{c}-1 \\
-869 \\
-906\end{array}$ & $\begin{array}{l}40 \\
70 \\
70\end{array}$ & $\begin{array}{c}0.006 \\
1 \\
0.011\end{array}$ & 4.105 \\
\hline 6.2 & $\begin{array}{c}1 \\
-869 \\
-905\end{array}$ & $\begin{array}{l}40 \\
70 \\
80\end{array}$ & $\begin{array}{c}0.006 \\
1 \\
0.006\end{array}$ & 4.13 \\
\hline 6.4 & $\begin{array}{c}2.6 \\
-869 \\
-905\end{array}$ & $\begin{array}{l}40 \\
75 \\
80\end{array}$ & $\begin{array}{c}0.007 \\
1 \\
0.006\end{array}$ & 4.18 \\
\hline 6.6 & $\begin{array}{c}2.6 \\
-868 \\
-905\end{array}$ & $\begin{array}{l}40 \\
75 \\
70\end{array}$ & $\begin{array}{c}0.007 \\
1 \\
0.006\end{array}$ & 4.28 \\
\hline 6.8 & $\begin{array}{c}1 \\
-587 \\
-869 \\
-903\end{array}$ & $\begin{array}{c}40 \\
240 \\
80 \\
70\end{array}$ & $\begin{array}{c}0.006 \\
0.013 \\
1 \\
0.006\end{array}$ & 4.34 \\
\hline 7.0 & $\begin{array}{c}1 \\
-586 \\
-869 \\
-904\end{array}$ & $\begin{array}{c}40 \\
250 \\
100 \\
100\end{array}$ & $\begin{array}{c}0.009 \\
0.032 \\
1 \\
0.006\end{array}$ & 4.50 \\
\hline 7.2 & $\begin{array}{c}1.1 \\
-587 \\
-867 \\
-905\end{array}$ & $\begin{array}{c}40 \\
240 \\
85 \\
80\end{array}$ & $\begin{array}{c}0.018 \\
0.078 \\
1 \\
0.082\end{array}$ & 4.64 \\
\hline 7.3 & $\begin{array}{c}1.1 \\
-587 \\
-869 \\
-906\end{array}$ & $\begin{array}{c}50 \\
250 \\
80 \\
80\end{array}$ & $\begin{array}{c}0.010 \\
0.304 \\
1 \\
0.193\end{array}$ & 4.84 \\
\hline 7.4 & $\begin{array}{c}2.6 \\
-585 \\
-869 \\
-905\end{array}$ & $\begin{array}{c}40 \\
250 \\
80 \\
80\end{array}$ & $\begin{array}{c}0.027 \\
0.430 \\
1 \\
0.067\end{array}$ & 5.14 \\
\hline
\end{tabular}


PNNL-22957

EMSP-RPT-018

\begin{tabular}{|c|c|c|c|c|}
\hline pH & $\begin{array}{c}\text { Chemical Shift of } \\
{ }^{99} \text { Tc Resonance, } \\
\text { ppm }\end{array}$ & $\begin{array}{c}\text { Half-width of }{ }^{99} \mathrm{Tc} \\
\text { Resonance, } \mathrm{Hz}\end{array}$ & Integration & Volume of Solution, ml \\
\hline 7.5 & $\begin{array}{c}1.1 \\
-586 \\
-869 \\
-905 \\
-1057\end{array}$ & $\begin{array}{c}40 \\
250 \\
80 \\
80 \\
100\end{array}$ & $\begin{array}{c}0.016 \\
0.495 \\
1 \\
0.067 \\
0.023\end{array}$ & 5.54 \\
\hline 7.6 & $\begin{array}{c}1 \\
-587 \\
-869 \\
-905 \\
-1054\end{array}$ & $\begin{array}{c}50 \\
240 \\
80 \\
80 \\
100\end{array}$ & $\begin{array}{c}0.020 \\
0.700 \\
1 \\
0.052 \\
0.043\end{array}$ & 5.84 \\
\hline 7.7 & $\begin{array}{c}2.6 \\
-585 \\
-869 \\
-905 \\
-1057\end{array}$ & $\begin{array}{c}50 \\
240 \\
80 \\
80 \\
90\end{array}$ & $\begin{array}{c}0.054 \\
0.780 \\
1 \\
0.026 \\
0.050\end{array}$ & 6.04 \\
\hline 7.8 & $\begin{array}{c}2.6 \\
-585 \\
-869 \\
-905 \\
-1057\end{array}$ & $\begin{array}{c}50 \\
240 \\
80 \\
80 \\
80\end{array}$ & $\begin{array}{c}0.062 \\
1.070 \\
1 \\
0.021 \\
0.084\end{array}$ & 6.12 \\
\hline $8.0^{\text {a) }}$ & $\begin{array}{c}1 \\
-585 \\
-869 \\
-1056\end{array}$ & $\begin{array}{c}50 \\
240 \\
100 \\
80\end{array}$ & $\begin{array}{l}0.067 \\
0.654 \\
1 \\
0.541\end{array}$ & 6.28 \\
\hline 14.0 & $\begin{array}{c}2.3 \\
-1056\end{array}$ & $\begin{array}{l}45 \\
80\end{array}$ & $\begin{array}{l}0.1 \\
1 \text { b) }\end{array}$ & 6.5 \\
\hline
\end{tabular}

a) Titration experiment was interrupted at a $\mathrm{pH}$ of 8 due to a power outage and shutdown of the NMR instrument.

b) Due to the absence of $\left[\mathrm{Tc}(\mathrm{CO})_{3}\left(\mathrm{H}_{2} \mathrm{O}\right)_{3}\right]^{+}$species, normalization is based on the $\left[\mathrm{Tc}(\mathrm{CO})_{3}(\mathrm{OH})\left(\mathrm{H}_{2} \mathrm{O}\right)_{2}\right]$ band. 
Table 2.5. Characterization of $1 \mathrm{~b}$ Speciation as a $\mathrm{pH}$ Function Observed by ${ }^{99} \mathrm{Tc}-\mathrm{NMR}$ Spectroscopy. Band assignment of each species with percent fraction shown in columns.

\begin{tabular}{|c|c|c|c|c|c|}
\hline pH & $\begin{array}{c}{\left[\mathrm{Tc}(\mathrm{CO})_{3}\left(\mathrm{H}_{2} \mathrm{O}\right)_{3}\right]^{+}} \\
-869 \mathrm{ppm}\end{array}$ & $\begin{array}{c}{\left[\mathrm{Tc}(\mathrm{CO})_{4}\left(\mathrm{H}_{2} \mathrm{O}\right)_{2}\right]^{+}} \\
-905 \mathrm{ppm}\end{array}$ & $\begin{array}{l}{\left[\mathrm{Tc}(\mathrm{CO})_{3}(\mathrm{OH})\right]_{4}} \\
-585 \mathrm{ppm}\end{array}$ & $\begin{array}{c}{\left[\mathrm{Tc}(\mathrm{CO})_{3}(\mathrm{OH})\left(\mathrm{H}_{2} \mathrm{O}\right)_{2}\right]} \\
-1056 \mathrm{ppm}\end{array}$ & $\begin{array}{l}\mathrm{TcO}_{4}^{-} \\
1 \text { ppm }\end{array}$ \\
\hline 1.15 & 1 & 0 & 0 & 0 & 0 \\
\hline 3.0 & 1 & 0 & 0 & 0 & 0 \\
\hline 4.0 & 0.990 & 0.006 & 0.001 & 0 & 0.003 \\
\hline 5.0 & 0.990 & 0.006 & 0.001 & 0 & 0.003 \\
\hline 6.0 & 0.990 & 0.006 & 0.001 & 0 & 0.003 \\
\hline 6.2 & 0.990 & 0.006 & 0.001 & 0 & 0.003 \\
\hline 6.4 & 0.990 & 0.006 & 0.001 & 0 & 0.003 \\
\hline 6.6 & 0.990 & 0.006 & 0.001 & 0 & 0.003 \\
\hline 6.8 & 0.976 & 0.006 & 0.013 & 0 & 0.005 \\
\hline 7.0 & 0.958 & 0.006 & 0.031 & 0 & 0.006 \\
\hline 7.2 & 0.856 & 0.070 & 0.067 & 0 & 0.007 \\
\hline 7.3 & 0.755 & 0.094 & 0.142 & 0 & 0.009 \\
\hline 7.4 & 0.660 & 0042 & 0.284 & 0 & 0.014 \\
\hline 7.5 & 0.623 & 0.038 & 0.309 & 0.014 & 0.016 \\
\hline 7.6 & 0.550 & 0.016 & 0.382 & 0.024 & 0.028 \\
\hline 7.7 & 0.524 & 0.006 & 0.409 & 0.026 & 0.048 \\
\hline 7.8 & 0.447 & 0.000 & 0.478 & 0.038 & 0.054 \\
\hline 8.0 & 0.442 & 0.000 & 0.289 & 0.239 & 0.060 \\
\hline 14.0 & 0 & 0 & 0 & 0.900 & 0.1 \\
\hline
\end{tabular}

The complete speciation diagram is presented in Figure 2.8. Pertechnetate and $\left[\mathrm{Tc}(\mathrm{CO})_{4}\left(\mathrm{H}_{2} \mathrm{O}\right)_{2}\right]^{+}$ constitute only minor constituents of the mixture.
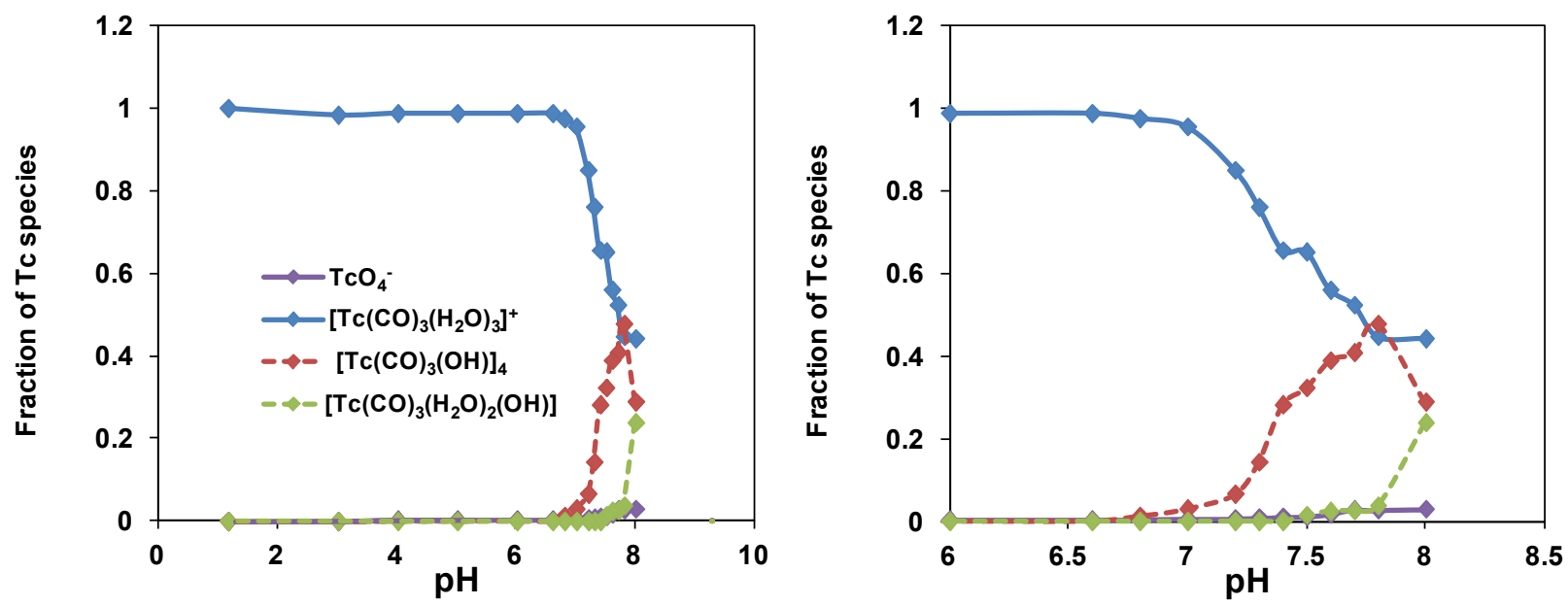

Figure 2.8. Speciation Distribution of Tc(I)-tricarbonyl Species and Pertechnetate as a Function of $\mathrm{pH}$

Based on the data reported in Table 2.4, the $\mathrm{pH}$ speciation diagram containing fractions of the $\left[\mathrm{Tc}(\mathrm{CO})_{3}\left(\mathrm{H}_{2} \mathrm{O}\right)_{3}\right]^{+}$and combined $\left\{\left[\mathrm{Tc}(\mathrm{CO})_{3}(\mathrm{OH})\right]_{4}+\left[\mathrm{Tc}(\mathrm{CO})_{3}(\mathrm{OH})\left(\mathrm{H}_{2} \mathrm{O}\right)_{2}\right]\right\}$ hydrolysis species was constructed (Figure 2.9). The first $\mathrm{p} K_{\mathrm{a}}$ value of the $\left[\mathrm{Tc}(\mathrm{CO})_{3}\left(\mathrm{H}_{2} \mathrm{O}\right)_{3}\right]^{+}$species was estimated to be 7.75 
based on the $\mathrm{pH}$ value at which concentrations of the parent $\left[\mathrm{Tc}(\mathrm{CO})_{3}\left(\mathrm{H}_{2} \mathrm{O}\right)_{3}\right]^{+}$species and hydrolysis product were equal.

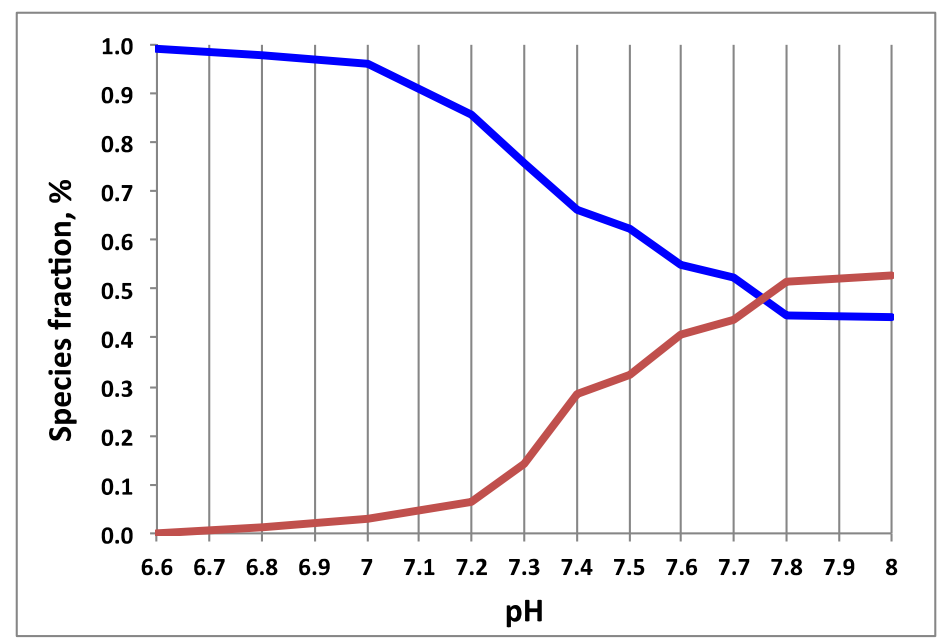

Figure 2.9. $\left[\mathrm{Tc}(\mathrm{CO})_{3}\left(\mathrm{H}_{2} \mathrm{O}\right)_{3}\right]^{+}$Speciation Diagram Obtained in the $\mathrm{pH}$ Titration Experiment. Blue trace: percent fraction of the $\left[\mathrm{Tc}(\mathrm{CO})_{3}\left(\mathrm{H}_{2} \mathrm{O}\right)_{3}\right]^{+}$species. Red trace: percent fraction of the combined $\left\{\left[\mathrm{Tc}(\mathrm{CO})_{3}(\mathrm{OH})\right]_{4}+\left[\mathrm{Tc}(\mathrm{CO})_{3}(\mathrm{OH})\left(\mathrm{H}_{2} \mathrm{O}\right)_{2}\right]\right\}$ species. Fractions of the $\left[\mathrm{Tc}(\mathrm{CO})_{4}\left(\mathrm{H}_{2} \mathrm{O}\right)_{2}\right]^{+}$and $\mathrm{TcO}_{4}^{-}$species are omitted for clarity.

\subsection{Preparation and Characterization of the $\left[\mathrm{Tc}(\mathrm{CO})_{3} \text { (gluconate) }\right]^{2-}$ Complex}

The initial attempt to prepare a $\left[\mathrm{Tc}(\mathrm{CO})_{3} \text { (gluconate) }\right]^{2-}$ complex was made using a solution of $\left[\mathrm{Tc}(\mathrm{CO})_{3}(\mathrm{OH})\left(\mathrm{H}_{2} \mathrm{O}\right)_{2}\right]$ in $1 \mathrm{M} \mathrm{NaOH}$ mixed in a 1:1 ratio with $0.2 \mathrm{M}$ potassium gluconate $/ 1 \mathrm{M} \mathrm{NaOH}$ solution. Based on the ${ }^{99} \mathrm{Tc}-\mathrm{NMR}$ data, this method did not generate the target product; only the $\left[\mathrm{Tc}(\mathrm{CO})_{3}(\mathrm{OH})\left(\mathrm{H}_{2} \mathrm{O}\right)_{2}\right]$ species was identified in the spectrum. This result was explained by the strong affinity of the $\left[\mathrm{Tc}(\mathrm{CO})_{3}\right]^{+}$moiety to the hydroxyl group and possible slow kinetics of $\mathrm{OH}^{-}$exchange with the gluconate ligand.

In an alternative route, $\left[\mathrm{Tc}(\mathrm{CO})_{3}(\text { gluconate })\right]^{2-}$ complex was prepared by the addition of the acidic $\left[\mathrm{Tc}(\mathrm{CO})_{3}\left(\mathrm{H}_{2} \mathrm{O}\right)_{3}\right]^{+}$solution to the $0.2-\mathrm{M}$ potassium gluconate/2-M NaOH mixture in a 1:1 ratio. It was observed that this method generated both $\left[\mathrm{Tc}(\mathrm{CO})_{3}(\mathrm{OH})\left(\mathrm{H}_{2} \mathrm{O}\right)_{2}\right]$ and the $\left[\mathrm{Tc}(\mathrm{CO})_{3}(\text { gluconate })\right]^{2-}$ species in the resulting solution.

In order to suppress the formation of the $\left[\mathrm{Tc}(\mathrm{CO})_{3}(\mathrm{OH})\left(\mathrm{H}_{2} \mathrm{O}\right)_{2}\right]$ species, the concentration of potassium pluconate was increased and the concentration of $\mathrm{NaOH}$ was decreased. In this method, the acidic $\left[\mathrm{Tc}(\mathrm{CO})_{3}\left(\mathrm{H}_{2} \mathrm{O}\right)_{3}\right]^{+}$solution was added to the $0.5-\mathrm{M}$ potassium gluconate/1.5-M NaOH mixture in a 1:1 ratio. The preparation of the $\left[\mathrm{Tc}(\mathrm{CO})_{3}(\text { gluconate })\right]^{2-}$ complex by this method was repeated several times with mixed results. The general conclusion is that at smaller total Tc(I) concentrations the formation of the $\left[\mathrm{Tc}(\mathrm{CO})_{3}(\mathrm{OH})\left(\mathrm{H}_{2} \mathrm{O}\right)_{2}\right]$ species is reduced. But reproducibility of the obtained concentration ratio of $\left[\mathrm{Tc}(\mathrm{CO})_{3}(\mathrm{OH})\left(\mathrm{H}_{2} \mathrm{O}\right)_{2}\right]$ and $\left[\mathrm{Tc}(\mathrm{CO})_{3}(\text { gluconate })\right]^{2-}$ complex was poor. Indeed, there were few repetitions in which the formation of the $\left[\mathrm{Tc}(\mathrm{CO})_{3}(\mathrm{OH})\left(\mathrm{H}_{2} \mathrm{O}\right)_{2}\right]$ species was not observed. It should be noted that the $\left[\mathrm{Tc}(\mathrm{CO})_{3}(\mathrm{OH})\left(\mathrm{H}_{2} \mathrm{O}\right)_{2}\right]$ can convert to the $\left[\mathrm{Tc}(\mathrm{CO})_{3}\right.$ (gluconate $\left.)\right]^{2-}$ complex as described below. 
In all preparations, formation of variable small amounts of $\mathrm{TcO}_{4}{ }^{-}$was found.

We conclude that several factors govern these competitive $\left[\mathrm{Tc}(\mathrm{CO})_{3}\right]^{+}$reactions, specifically hydrolysis with complexation to gluconate. These factors include: the Tc(I):gluconate concentration ratio, the volumes of the mixing solutions, the method of mixing reactants, and others.

The ${ }^{99} \mathrm{Tc}-\mathrm{NMR}$ spectrum of the $\left[\mathrm{Tc}(\mathrm{CO})_{3} \text { (gluconate) }\right]^{2-}$ complex demonstrated two bands at -1230 and $-1247 \mathrm{ppm}$ with corresponding half-widths of 270 and $300 \mathrm{~Hz}$. The positions and profiles of these resonances were observed to be nearly identical for all $\left[\mathrm{Tc}(\mathrm{CO})_{3} \text { (gluconate) }\right]^{2-}$ samples tested, regardless of the preparation method or $\mathrm{Tc}(\mathrm{I})$ :gluconate concentration ratio. The consistent appearance of two resonances suggests the presence of two non-equivalent $\mathrm{Tc}(\mathrm{I})$ centers in the Tc-tricarbonyl-gluconate complex.

The FTIR spectrum of the gluconate complex (Figure 2.10) exhibits both the symmetric carbonyl stretch vibrations at 1926 and $2030 \mathrm{~cm}^{-1}$ and the asymmetric carbonyl stretch vibrations at 1725 and $1777 \mathrm{~cm}^{-1}$. These bands are nearly identical to the corresponding carbonyl bands in $\left[\mathrm{Tc}(\mathrm{CO})_{3} \mathrm{Cl}_{3}\right]^{2-}$ (Figure 2.1 and Figure 2.5).

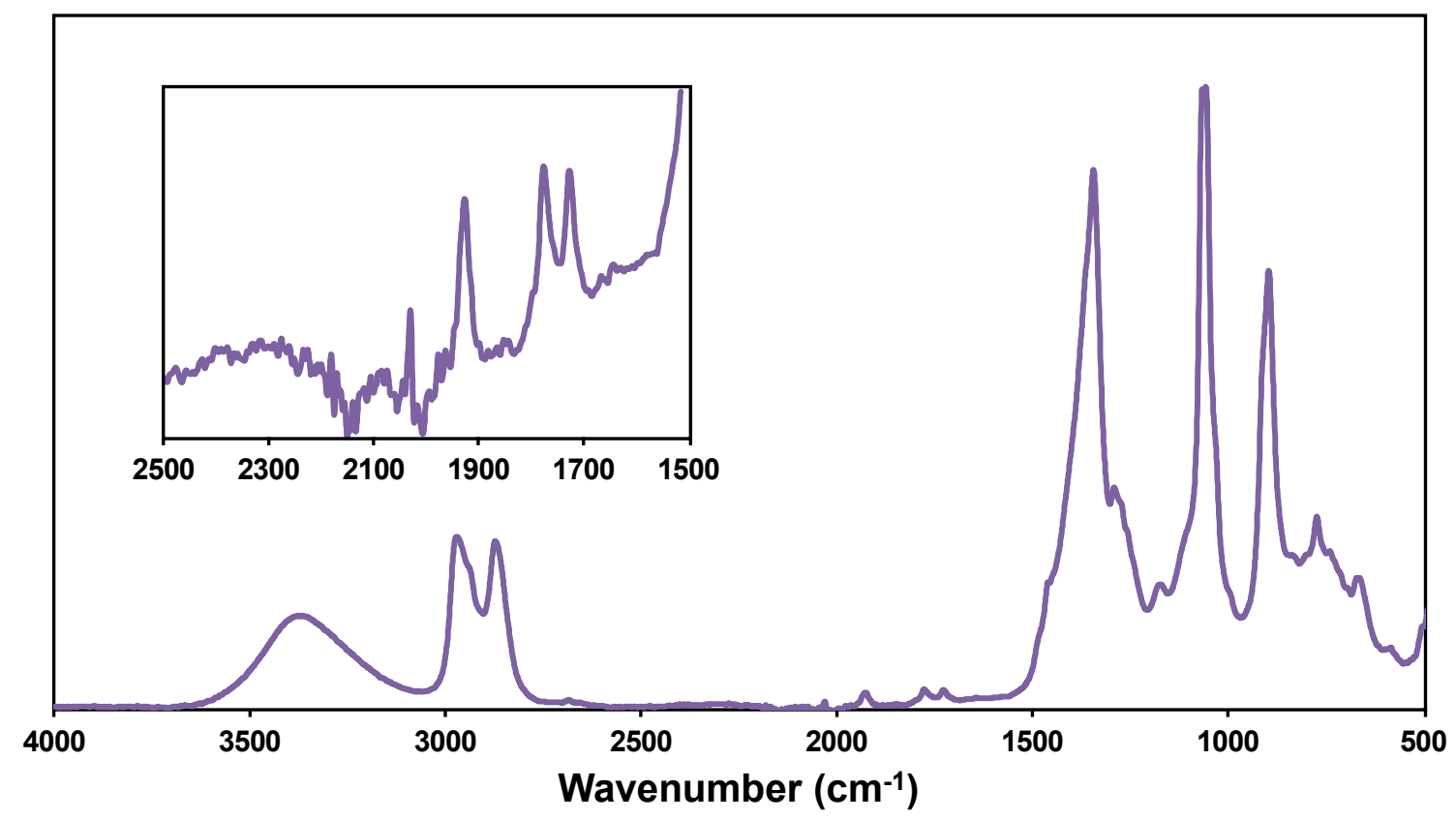

Figure 2.10. Infrared Spectrum of $\left[\mathrm{Tc}(\mathrm{CO})_{3} \text { (gluconate) }\right]^{2-}$. Inset shows the symmetric (1926 and $\left.2030 \mathrm{~cm}^{-1}\right)$ and asymmetric $\left(1714\right.$ and $\left.1765 \mathrm{~cm}^{-1}\right) \mathrm{C}=\mathrm{O}$ stretching modes.

\subsection{Ultraviolet Characterization of the $\left[\mathrm{Tc}(\mathrm{CO})_{3}\right]^{+}$Species}

The most prominent $\left[\mathrm{Tc}(\mathrm{CO})_{3}\right]^{+}$species, including $\left[\mathrm{Tc}(\mathrm{CO})_{3}\left(\mathrm{H}_{2} \mathrm{O}\right)_{3}\right]^{+}$in the acidic $0.2 \mathrm{M} \mathrm{HCl}$ solution, $\left[\mathrm{Tc}(\mathrm{CO})_{3}(\mathrm{OH})\right]_{4}$ in the mildly alkaline solution, $\left[\mathrm{Tc}(\mathrm{CO})_{3}(\mathrm{OH})\left(\mathrm{H}_{2} \mathrm{O}\right)_{2}\right]$ at $\mathrm{pH}$ of 14 , and $\left[\mathrm{Tc}(\mathrm{CO})_{3} \text { (gluconate) }\right]^{2-}$ complex in $0.25 \mathrm{M}$ potassium gluconate $/ 0.7 \mathrm{M} \mathrm{NaOH}$ were characterized by ultraviolet (UV) spectroscopy (Figure 2.11). The $\left[\mathrm{Tc}(\mathrm{CO})_{3}\left(\mathrm{H}_{2} \mathrm{O}\right)_{3}\right]^{+}$species exhibited a broad band at about 230-300 $\mathrm{nm}$ in agreement with an earlier report by Gorshkov et al. (2000). The UV profiles of 
mono-hydroxo species were found to be similar, with the $280 \mathrm{~nm}$ band corresponding to $\left[\mathrm{Tc}(\mathrm{CO})_{3}(\mathrm{OH})\left(\mathrm{H}_{2} \mathrm{O}\right)_{2}\right]$ shifted to $290 \mathrm{~nm}$ for the tetramer compound. The $\left[\mathrm{Tc}(\mathrm{CO})_{3}(\text { gluconate })\right]^{2-}$ complex exhibits two strong bands at 246 and $277 \mathrm{~nm}$.

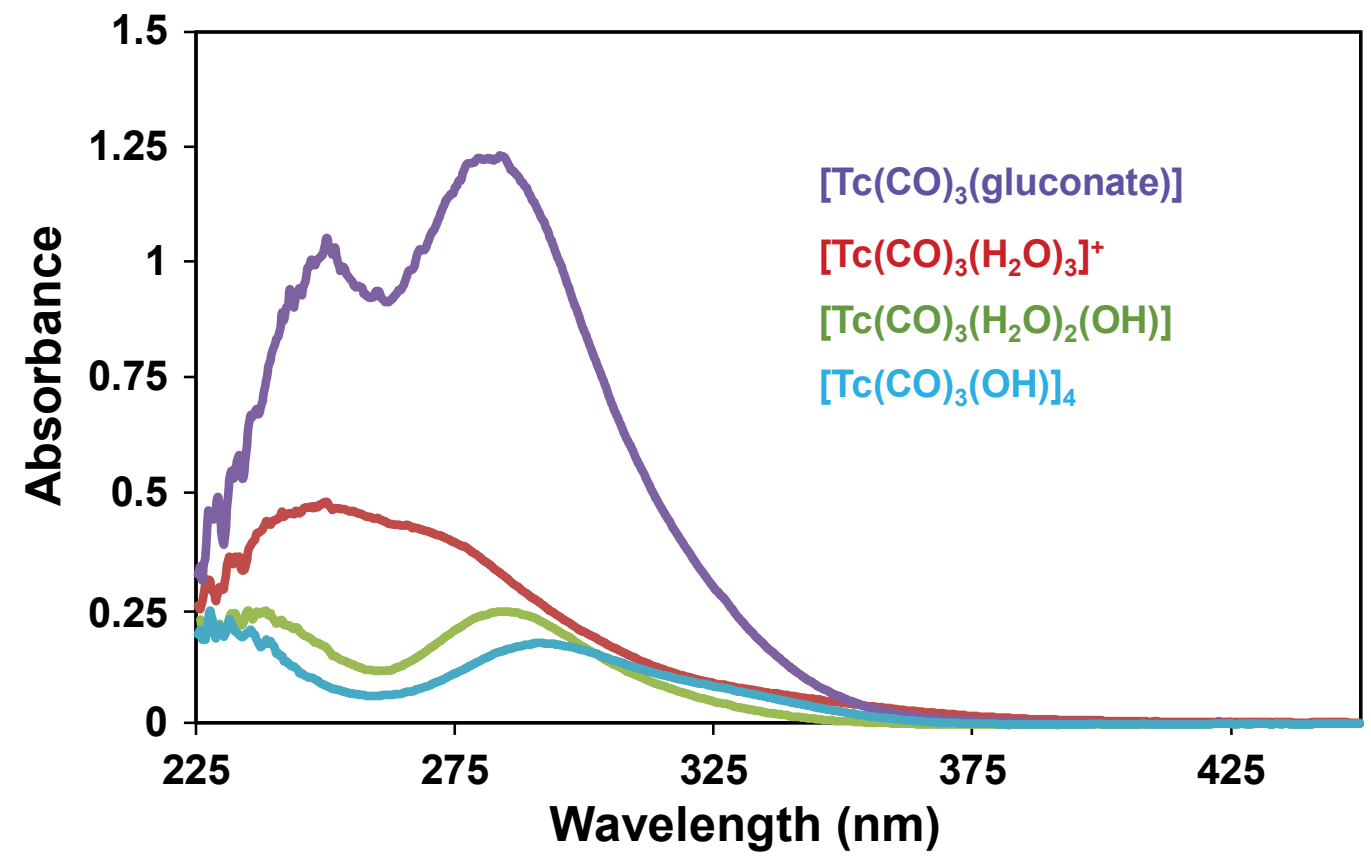

Figure 2.11. UV-Visible Spectra of Aqueous Solutions of $\left[\mathrm{Tc}(\mathrm{CO})_{3} \text { (gluconate) }\right]^{2-}$ in $0.25 \mathrm{M}$ Potassium Gluconate/0.7 M NaOH, $\left[\mathrm{Tc}(\mathrm{CO})_{3}\left(\mathrm{H}_{2} \mathrm{O}\right)_{3}\right]^{+}$in $0.2 \mathrm{M} \mathrm{HCl},\left[\mathrm{Tc}(\mathrm{CO})_{3}\left(\mathrm{H}_{2} \mathrm{O}\right)_{2}(\mathrm{OH})\right]$ at $\mathrm{pH}=14$, and $\left[\mathrm{Tc}(\mathrm{CO})_{3}(\mathrm{OH})\right]_{4}$ at $\mathrm{pH}=8$. Spectra are not normalized to Tc concentration.

\subsection{Air Stability of the $\left[\mathrm{Tc}(\mathrm{CO})_{3}\right]^{+}$Species}

\subsection{1 $\left[\mathrm{Tc}(\mathrm{CO})_{3}\left(\mathrm{H}_{2} \mathrm{O}\right)_{3}\right]^{+}$in $0.2 \mathrm{M} \mathrm{HCl}$}

The $\left[\mathrm{Et}_{4} \mathrm{~N}\right]_{2}\left[\mathrm{Tc}(\mathrm{CO})_{3} \mathrm{Cl}_{3}\right]$ material obtained during Synthesis 10 was warmed with water at $60^{\circ} \mathrm{C}$ for two hours. Then it was mixed with $\mathrm{HCl}$ solution so that the final matrix was adjusted to $0.2 \mathrm{M} \mathrm{HCl}$. The resulting material contained $\left[\mathrm{Tc}(\mathrm{CO})_{3}\left(\mathrm{H}_{2} \mathrm{O}\right)_{3}\right]^{+}$and $\mathrm{TcO}_{4}{ }^{-}$in 0.77:0.23 ratio. This solution was monitored by ${ }^{99} \mathrm{Tc}-\mathrm{NMR}$ spectroscopy over one month. The results are shown in Table 2.6 and Figure 2.12. 
Table 2.6. Time Stability of $\left[\mathrm{Tc}(\mathrm{CO})_{3}\left(\mathrm{H}_{2} \mathrm{O}\right)_{3}\right]^{+}$in $0.2 \mathrm{M} \mathrm{HCl} \mathrm{Solution}$

\begin{tabular}{|c|c|c|}
\hline \multirow{2}{*}{ Time Elapsed } & \multicolumn{2}{|c|}{ Percent Fraction } \\
\hline 3 hours & {$\left[\mathbf{T c}(\mathbf{C O})_{\mathbf{3}}\left(\mathbf{H}_{\mathbf{2}} \mathbf{O}\right)_{3}\right]^{+}$} & $\mathbf{T c O}_{4}{ }^{-}$ \\
\hline $\mathbf{1}$ day & 0.77 & 0.23 \\
\hline $\mathbf{2}$ days & 0.74 & 0.26 \\
\hline $\mathbf{3}$ days & 0.72 & 0.28 \\
\hline $\mathbf{5}$ days & 0.71 & 0.29 \\
\hline $\mathbf{7}$ days & 0.65 & 0.35 \\
\hline $\mathbf{1 0}$ days & 0.56 & 0.44 \\
\hline & 0.33 & 0.67 \\
\hline
\end{tabular}

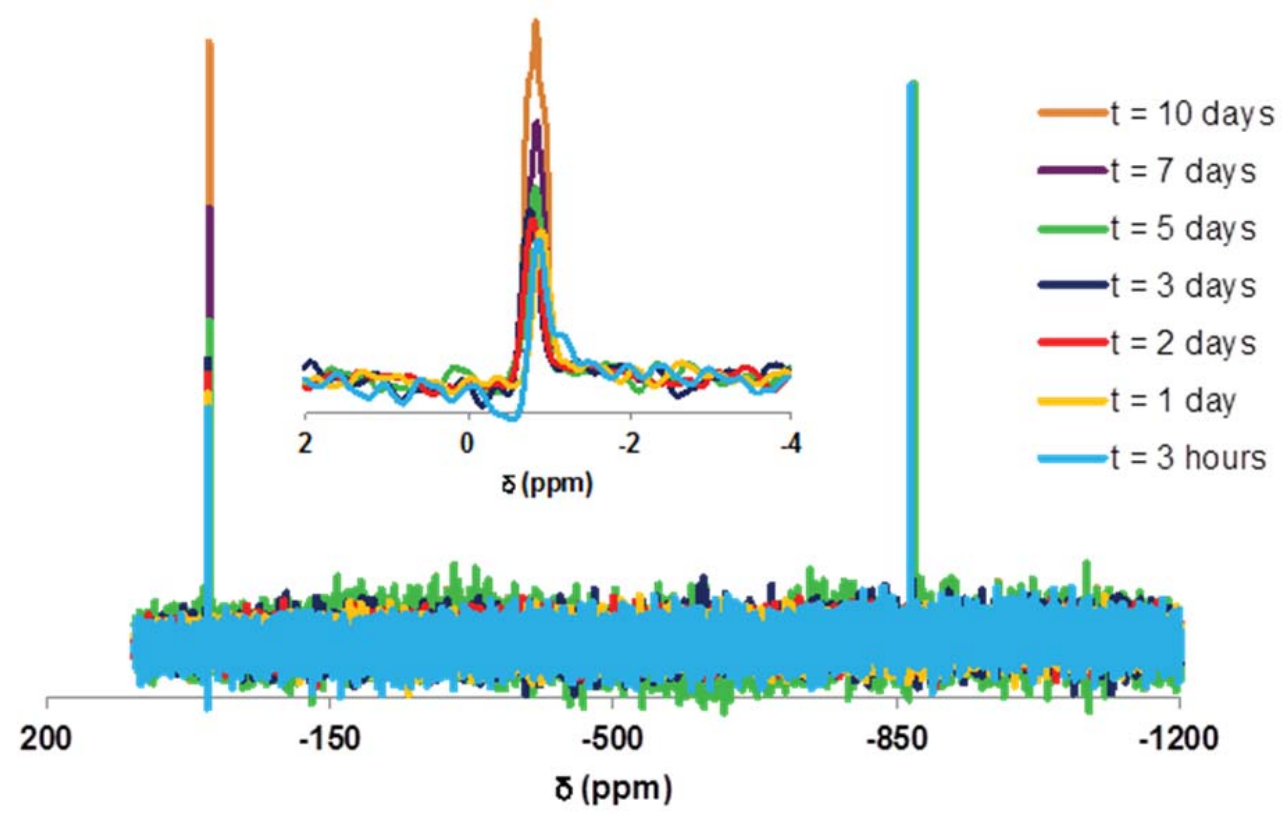

Figure 2.12. Monitoring the Stability of $\left[\mathrm{Tc}(\mathrm{CO})_{3}\left(\mathrm{H}_{2} \mathrm{O}\right)_{3}\right]^{+}$Species in $0.2 \mathrm{M} \mathrm{HCl}$ with Time. The intensities of the NMR bands are normalized with respect to the $\left[\mathrm{Tc}(\mathrm{CO})_{3}\left(\mathrm{H}_{2} \mathrm{O}\right)_{3}\right]^{+}$ resonance at $-865 \mathrm{ppm}$. Inset shows increase in intensity of the $\mathrm{TcO}_{4}{ }^{-}$resonance with time.

A gradual decrease in the $\left[\mathrm{Tc}(\mathrm{CO})_{3}\left(\mathrm{H}_{2} \mathrm{O}\right)_{3}\right]^{+}$signal, together with an increase in the $\mathrm{TcO}_{4}{ }^{-}$band intensities, indicate that the former undergoes slow aerial oxidation. It is also possible that either in the initial $\left[\mathrm{Tc}(\mathrm{CO})_{3}\left(\mathrm{H}_{2} \mathrm{O}\right)_{3}\right]^{+}$-containing solution or during the initial heating with water, the ${ }^{99} \mathrm{Tc}-\mathrm{NMR}$-silent species Tc(II and/or IV) were present, which either selectively oxidized to pertechnetate or catalyzed the oxidation of $\mathrm{Tc}(\mathrm{I})$. It would be useful to repeat this study using purified starting material to quantitate the stability of the $\left[\mathrm{Tc}(\mathrm{CO})_{3}\left(\mathrm{H}_{2} \mathrm{O}\right)_{3}\right]^{+}$species in acidic solution. 


\subsection{2 $\left[\mathrm{Tc}(\mathrm{CO})_{3}(\mathrm{OH})\left(\mathrm{H}_{2} \mathrm{O}\right)_{3}\right]$ at $\mathrm{pH}=13.5$}

Fifteen milligrams of the precipitate obtained in Synthesis 11 was dissolved in $1.5 \mathrm{ml}$ of DI water; its $\mathrm{pH}$ was initially measured at 7.5 and then adjusted to 13.5 by addition of $\mathrm{NaOH} .{ }^{99} \mathrm{Tc}-\mathrm{NMR}$ spectroscopic analysis indicated that this solution initially contained $\left[\mathrm{Tc}(\mathrm{CO})_{3}(\mathrm{OH})\left(\mathrm{H}_{2} \mathrm{O}\right)_{2}\right]$ and $\mathrm{TcO}_{4}{ }^{-}$in a 0.84:0.16 ratio. This alkaline solution was monitored by ${ }^{99} \mathrm{Tc}-\mathrm{NMR}$ spectroscopy over one month. The results are shown in Table 2.7 and Figure 2.13.

Table 2.7. Stability of $\left[\mathrm{Tc}(\mathrm{CO})_{3}(\mathrm{OH})\left(\mathrm{H}_{2} \mathrm{O}\right)_{2}\right]$ at $\mathrm{pH}=13.5$ with Time

\begin{tabular}{|c|c|c|}
\hline \multirow{2}{*}{ Time Elapsed } & \multicolumn{3}{|c|}{ Percent Fraction } \\
\hline $\mathbf{1 5}$ min & {$\left[\mathbf{T c}(\mathbf{C O})_{\mathbf{3}}(\mathbf{O H})\left(\mathbf{H}_{\mathbf{2}} \mathbf{O}\right)_{\mathbf{2}}\right]$} & $\mathbf{T c O}_{\mathbf{4}}{ }^{-}$ \\
\hline $\mathbf{3}$ days & 0.84 & 0.16 \\
\hline $\mathbf{6}$ days & 0.80 & 0.20 \\
\hline $\mathbf{1 4}$ days & 0.75 & 0.25 \\
\hline $\mathbf{3 0}$ days & 0.70 & 0.30 \\
\hline
\end{tabular}

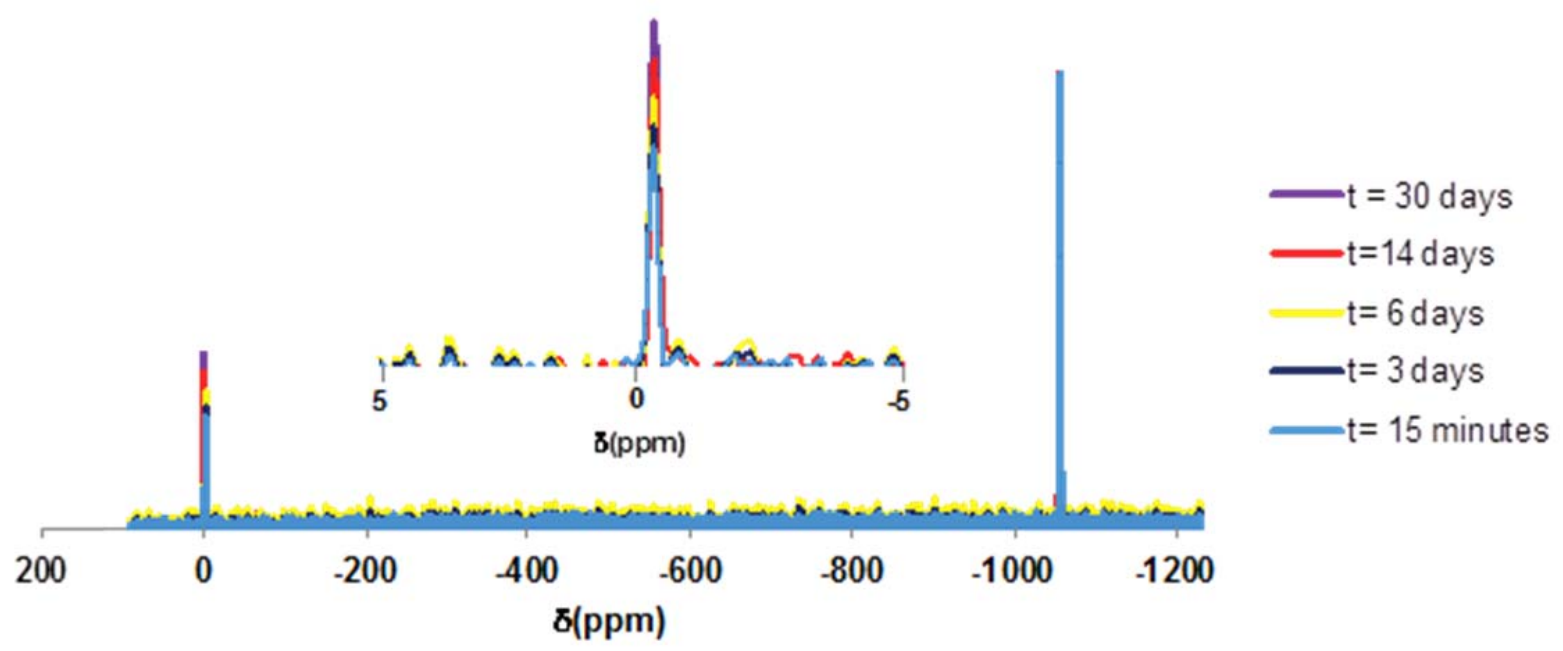

Figure 2.13. Spectral Plot of the Stability of $\left[\mathrm{Tc}(\mathrm{CO})_{3}\left(\mathrm{H}_{2} \mathrm{O}\right)_{2}(\mathrm{OH})\right]$ Species at $\mathrm{pH}=13.5$ with Time as Observed by NMR. Intensities of the NMR bands are normalized with respect to $\left[\mathrm{Tc}(\mathrm{CO})_{3}\left(\mathrm{H}_{2} \mathrm{O}\right)_{2}(\mathrm{OH})\right]$ resonance at $-1056 \mathrm{ppm}$. Inset shows increase in intensity of the $\mathrm{TcO}_{4}{ }^{-}$resonance with time.

A gradual decrease in the $\left[\mathrm{Tc}(\mathrm{CO})_{3}(\mathrm{OH})\left(\mathrm{H}_{2} \mathrm{O}\right)_{3}\right]{ }^{99} \mathrm{Tc}-\mathrm{NMR}$ signal and concomitant increase in the ${ }^{99} \mathrm{Tc}-\mathrm{NMR} \mathrm{TcO}_{4}{ }^{-}$signal suggests that the former undergoes slow aerial oxidation to the latter.

Surprisingly, the stability of the mono-hydroxo derivative was found to be greater than that of the parent $\left[\mathrm{Tc}(\mathrm{CO})_{3}\left(\mathrm{H}_{2} \mathrm{O}\right)_{3}\right]^{+}$species as evidenced by the comparison of the data reported in Tables 2.6 and 2.7.

Interestingly, no tetrameric $\left[\mathrm{Tc}(\mathrm{CO})_{3}(\mathrm{OH})\right]_{4}$ species was observed. This result is consistent with the observation made during the titration experiment described above demonstrating that the tetramer species 
exists primarily at mildly alkaline $\mathrm{pHs}$; more alkaline conditions lead to increasing formation of the monomer species.

\subsection{3 $\left[\mathrm{Tc}(\mathrm{CO})_{3}(\mathrm{OH})\left(\mathrm{H}_{2} \mathrm{O}\right)_{2}\right]$ at $\mathrm{pH}=8$}

About $6 \mathrm{mg}$ of $\left[\mathrm{Et}_{4} \mathrm{~N}\right]_{2}\left[\mathrm{Tc}(\mathrm{CO})_{3} \mathrm{Cl}_{3}\right]$-containing precipitate obtained in Synthesis 11 was dissolved in $3 \mathrm{ml}$ of DI water and its $\mathrm{pH}$ was immediately adjusted to 8 by addition of $\mathrm{NaOH} .{ }^{99} \mathrm{Tc} \mathrm{NMR}$ showed the presence of the single $\left[\mathrm{Tc}(\mathrm{CO})_{3}(\mathrm{OH})\left(\mathrm{H}_{2} \mathrm{O}\right)_{2}\right]$ species. This sample was monitored by ${ }^{99} \mathrm{Tc}-\mathrm{NMR}$ spectroscopy over 3 days. The results are shown in Table 2.8 and some representative spectra are shown in Figure 2.14.

Table 2.8. Stability of $\left[\mathrm{Tc}(\mathrm{CO})_{3}(\mathrm{OH})\left(\mathrm{H}_{2} \mathrm{O}\right)_{3}\right]$ at $\mathrm{pH} 8$ with Time

\begin{tabular}{|c|c|c|c|}
\hline \multirow{2}{*}{ Time Elapsed } & \multicolumn{3}{|c|}{ Percent Fraction } \\
\cline { 2 - 4 } & {$\left[\mathbf{T c}(\mathbf{C O})_{3}(\mathbf{O H})\left(\mathbf{H}_{\mathbf{2}} \mathbf{O}\right)_{2}\right]$} & {$\left[\mathbf{T c}(\mathbf{C O})_{3}(\mathbf{O H})\right]_{4}$} & $\mathbf{T c O}_{\mathbf{4}}{ }^{-}$ \\
\hline $\mathbf{6}$ minutes & 1 & 0 & 0 \\
\hline $\mathbf{6}$ hours & 0.59 & 0.23 & 0.18 \\
\hline $\mathbf{4 8}$ hours & 0.35 & 0.35 & 0.30 \\
\hline $\mathbf{7 2}$ hours & 0.14 & 0.46 & 0.40 \\
\hline
\end{tabular}

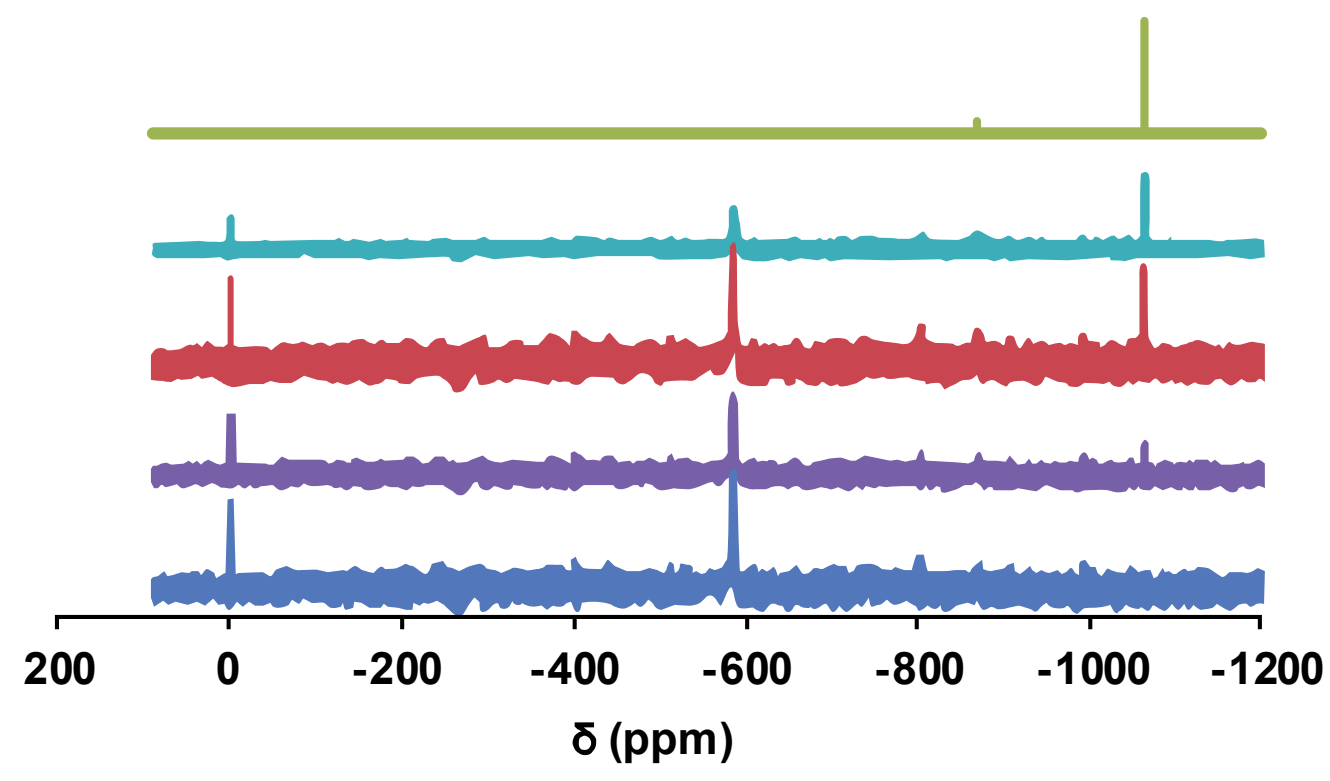

Figure 2.14. Monitoring the Stability of $\left[\mathrm{Tc}(\mathrm{CO})_{3}\left(\mathrm{H}_{2} \mathrm{O}\right)_{2}(\mathrm{OH})\right]$ Species at $\mathrm{pH} 8$ with Time. Over time (3 days), the $\left[\mathrm{Tc}(\mathrm{CO})_{3}\left(\mathrm{H}_{2} \mathrm{O}\right)_{2}(\mathrm{OH})\right]$ species (chemical shift $=-1056 \mathrm{ppm}$ ) is converted to the tetramer $\left[\mathrm{Tc}(\mathrm{CO})_{3}(\mathrm{OH})\right]_{4}$ (chemical shift $\left.=-585 \mathrm{ppm}\right)$. Traces: Olive (15 minutes), Aqua (6 hours), Red (1 day), Purple (2 days) and Blue (3 days). 
Fast conversion of $\left[\mathrm{Tc}(\mathrm{CO})_{3}(\mathrm{OH})\left(\mathrm{H}_{2} \mathrm{O}\right)_{2}\right]$ species to tetramer $\left[\mathrm{Tc}(\mathrm{CO})_{3}(\mathrm{OH})\right]_{4}$ was observed. Within three days, almost the entire $\left[\mathrm{Tc}(\mathrm{CO})_{3}\left(\mathrm{H}_{2} \mathrm{O}\right)_{2}(\mathrm{OH})\right]$ population got converted to the tetramer.

Simultaneously with this conversion process $\mathrm{TcO}_{4}{ }^{-}$was generated so that the concentration of $\mathrm{TcO}_{4}{ }^{-}$was only smaller than the tetramer concentration at the conclusion of the measurement. In short, $45 \%$ of $\left[\mathrm{Tc}(\mathrm{CO})_{3}(\mathrm{OH})\left(\mathrm{H}_{2} \mathrm{O}\right)_{2}\right]$ was oxidized to $\mathrm{TcO}_{4}{ }^{-}$over 3 days. By way of comparison, the $\left[\mathrm{Tc}(\mathrm{CO})_{3}(\mathrm{OH})\left(\mathrm{H}_{2} \mathrm{O}\right)_{2}\right]$ species was much more stable at a $\mathrm{pH}$ of 13.5 , generating only an additional $4 \%$ of $\mathrm{TcO}_{4}{ }^{-}$over the same time period (Table 2.7).

From this data we tentatively conclude that the limited stability to oxidation from $\mathrm{Tc}(\mathrm{I})$ to $\mathrm{Tc}(\mathrm{VII})$ of the $\left[\mathrm{Tc}(\mathrm{CO})_{3}\right]^{+}$moiety is related to the formation of the $\left[\mathrm{Tc}(\mathrm{CO})_{3}(\mathrm{OH})\right]_{4}$ tetramer at mildly alkaline $\mathrm{pH}$.

\subsection{4 $\left[\mathrm{Tc}(\mathrm{CO})_{3} \text { (gluconate) }\right]^{2-}$ in $0.7 \mathrm{M} \mathrm{NaOH}$}

Thirty milligrams of the precipitate obtained in Synthesis 11 were dissolved in $3 \mathrm{ml}$ of DI water and the solution's $\mathrm{pH}$ adjusted to $\sim 1.5$ by the addition of $5 \mathrm{M} \mathrm{HCl} .{ }^{99} \mathrm{Tc}$ NMR exhibited the $\left[\mathrm{Tc}(\mathrm{CO})_{3}\left(\mathrm{H}_{2} \mathrm{O}\right)_{3}\right]^{+}$ band, with no band revealing $\mathrm{TcO}_{4}^{-}$. $1.5 \mathrm{ml}$ of the resulting solution was added to $1.5 \mathrm{ml}$ of $0.5 \mathrm{M}$ potassium gluconate in $1.5 \mathrm{M} \mathrm{NaOH}$ resulting in a solution of $0.25 \mathrm{M}$ potassium gluconate $/ 0.7 \mathrm{M} \mathrm{NaOH}$.

The initial NMR analysis indicated that the resulting mixture contained $\left[\mathrm{Tc}(\mathrm{CO})_{3}(\mathrm{OH})\left(\mathrm{H}_{2} \mathrm{O}\right)_{2}\right]$ species at a significantly larger concentration than the gluconate complex (Table 2.9 and Table 2.10).

Pertechnetate constituted about $15 \%$ of the total ${ }^{99} \mathrm{Tc}$. Six hours post solution preparation, the $\left[\mathrm{Tc}(\mathrm{CO})_{3}(\mathrm{OH})\left(\mathrm{H}_{2} \mathrm{O}\right)_{2}\right]$ was completely converted to about equal amounts of $\left[\mathrm{Tc}(\mathrm{CO})_{3} \text { (gluconate) }\right]^{2-}$ and $\mathrm{TcO}_{4}^{-}$.

The percent-fraction of $\left[\mathrm{Tc}(\mathrm{CO})_{3}(\text { gluconate })\right]^{2-}$ complex gradually decreased with time due to the oxidation to $\mathrm{Tc}(\mathrm{VII})$ and formation of $\mathrm{TcO}_{4}^{-}$. In 30 days, about $30 \%$ of $\left[\mathrm{Tc}(\mathrm{CO})_{3} \text { (gluconate) }\right]^{2-}$ had decomposed.

Table 2.9. Monitoring $\left[\mathrm{Tc}(\mathrm{CO})_{3}(\text { gluconate })\right]^{2-}$ Complex Stability with Time Starting from $\left[\mathrm{Tc}(\mathrm{CO})_{3}(\mathrm{OH})\left(\mathrm{H}_{2} \mathrm{O}\right)_{2}\right] ;(\mathrm{A})$ the $\mathrm{TcO}_{4}{ }^{-}$Band Intensity Increases with Time (chemical shift $=-1 \mathrm{ppm})$; (B) Initial Conversion of $\left[\mathrm{Tc}(\mathrm{CO})_{3}(\mathrm{OH})\left(\mathrm{H}_{2} \mathrm{O}\right)_{2}\right]$ (chemical shift $=-1056 \mathrm{ppm})$ to the $\left[\mathrm{Tc}(\mathrm{CO})_{3}(\text { gluconate })\right]^{2-}$ Complex and its Time Stability (chemical shift $=-1230$ and -1247 ppm)

\begin{tabular}{|c|c|c|c|}
\hline Species & Chemical Shift $(\mathbf{p p m})$ & Average Half-width & Stable pH Range \\
\hline $\mathbf{T c O}_{4}^{-}$ & 0 & 40 & No dependence \\
\hline$\left[\mathbf{T c}(\mathbf{C O})_{3}\left(\mathbf{H}_{2} \mathbf{O}\right)_{3}\right]^{+}$ & -869 & 80 & $1-7$ \\
\hline$\left[\mathbf{T c}(\mathbf{C O})_{3}(\mathbf{O H})\left(\mathbf{H}_{2} \mathbf{O}\right)_{2}\right]$ & -1060 & 90 & $<7$ \\
\hline$\left[\mathbf{T c}(\mathbf{C O})_{3}(\mathbf{O H})_{2}\left(\mathbf{H}_{2} \mathbf{O}\right)\right]^{-}$ & -1146 & 100 & {$[\mathrm{OH}]^{-}>2 \mathrm{M}$} \\
\hline$\left[\mathbf{T c}(\mathbf{C O})_{3}(\mathbf{O H})_{3}\right]^{2-}$ & -1482 & 25 & {$[\mathrm{OH}]^{>}>2 \mathrm{M}$} \\
\hline$\left[\mathbf{T c}(\mathbf{C O})_{3}(\mathbf{O H})\right]_{4}$ & -585 & 250 & $7-8$ \\
\hline$\left[\mathbf{T c}(\mathbf{C O})_{4}\left(\mathbf{H}_{2} \mathbf{O}\right)_{2}\right]^{+}$ & -901 & 70 & $4-8$ \\
\hline$\left[\mathbf{T c}(\mathbf{C O})_{3} \mathbf{G l u c o n a t e}^{-}\right.$ & $-1230,-1247$ & 270,300 & {$[\mathrm{OH}]^{-}>0.1 \mathrm{M}$} \\
\hline
\end{tabular}


Table 2.10. Stability of $\left[\mathrm{Tc}(\mathrm{CO})_{3}\right.$ (gluconate $\left.)\right]^{2-}$ in $0.7 \mathrm{M} \mathrm{NaOH}$ with Time

\begin{tabular}{|c|c|c|c|}
\hline \multirow[b]{2}{*}{ Time Elapsed } & \multicolumn{3}{|c|}{ Percent Fraction } \\
\hline & $\begin{array}{c}{\left[\mathrm{Tc}(\mathrm{CO})_{3}(\mathrm{OH})\left(\mathrm{H}_{2} \mathrm{O}\right)_{3}\right]} \\
-1056 \mathrm{ppm}\end{array}$ & $\begin{array}{l}{\left[\mathrm{Tc}(\mathrm{CO})_{3}(\text { gluconate })\right]^{2-}} \\
\left.-1230 \text { and }-1247 \mathrm{ppm}^{\mathrm{a}}\right)\end{array}$ & $\begin{array}{l}\mathrm{TcO}_{4}^{-} \\
1 \mathrm{ppm}\end{array}$ \\
\hline 2 hours & 0.75 & 0.10 & 0.15 \\
\hline 6 hours & _ & 0.50 & 0.50 \\
\hline 2 days & _- & 0.47 & 0.53 \\
\hline 7 days & - & 0.42 & 0.58 \\
\hline 14 days & - & 0.38 & 0.62 \\
\hline 30 days & _- & 0.35 & 0.65 \\
\hline
\end{tabular}

\subsection{Discussion of $\mathrm{Tc}(\mathrm{I})$ Tricarbonyl Syntheses, Speciation, and Air Stability}

Extensive experimentation was performed to test various literature synthetic procedures for obtaining a clean $\left[\mathrm{Tc}(\mathrm{CO})_{3}\right]^{+}$compound for further study and derivative preparations. The results of these experiments indicated that it is not feasible to obtain the $\left[\mathrm{Tc}(\mathrm{CO})_{3}\left(\mathrm{H}_{2} \mathrm{O}\right)_{3}\right]^{+}$complex by synthetic conditions involving alkaline aqueous media because of the extensive hydrolysis of the product and re-oxidation of the tricarbonyl $\mathrm{Tc}(\mathrm{I})$ species to $\mathrm{TcO}_{4}{ }^{-}$. We conclude that the most viable option is to use organic-solution-based preparations of $\left[\mathrm{Tc}(\mathrm{CO})_{3} \mathrm{Cl}_{3}\right]^{2-}$; this compound provides a stable and reliable source of Tc(I) that can be easily converted to the desired $\left[\mathrm{Tc}(\mathrm{CO})_{3}\left(\mathrm{H}_{2} \mathrm{O}\right)_{3}\right]^{+}$as needed. It was observed that a two-step reductive approach to synthesis of $\left[\mathrm{Tc}(\mathrm{CO})_{3} \mathrm{Cl}_{3}\right]^{2-}$ appears to offer a better yield and possesses more favorable product purification behavior than is found in the alternative one-pot reduction of $\mathrm{Tc}(\mathrm{VII})$ to $\mathrm{Tc}(\mathrm{I})$ in an organic solvent. The first step involves a reduction of $\mathrm{TcO}_{4}{ }^{-}$to $\mathrm{Tc}(\mathrm{V})$ and isolation of $\left[\mathrm{Bu}_{4} \mathrm{~N}\right]\left[\mathrm{TcOCl}_{4}\right]$ compound; the second is the reduction of the $\mathrm{Tc}(\mathrm{V})$ compound to $\mathrm{Tc}(\mathrm{I})$ in the form of $\left[\mathrm{Tc}(\mathrm{CO})_{3} \mathrm{Cl}_{3}\right]^{2-}$. Even so, further optimization of the reaction conditions to improve both reaction yield and purification of the $\left[\mathrm{Tc}(\mathrm{CO})_{3} \mathrm{Cl}_{3}\right]^{2-}$ product is warranted.

We have confirmed that this $\left[\mathrm{Tc}(\mathrm{CO})_{3} \mathrm{Cl}_{3}\right]^{2-}$ precursor can easily be converted to $\left[\mathrm{Tc}(\mathrm{CO})_{3}\left(\mathrm{H}_{2} \mathrm{O}\right)_{3}\right]^{+}$by the exchange reaction in acidified water at elevated temperatures. During this reaction, any $\left[\mathrm{Tc}(\mathrm{CO})_{4} \mathrm{Cl}_{2}\right]^{-}$ that may be present as a co-product will exchange two $\mathrm{Cl}$ - groups and a mobile trans-CO group (Miroslavov et al. 1990) for water, leading to the same $\left[\mathrm{Tc}(\mathrm{CO})_{3}\left(\mathrm{H}_{2} \mathrm{O}\right)_{3}\right]^{+}$species as does $\left[\mathrm{Tc}(\mathrm{CO})_{3} \mathrm{Cl}_{3}\right]^{2-}$.

This work demonstrates how NMR analysis based on the ${ }^{99} \mathrm{Tc}$ nucleus can be a powerful method of identifying ${ }^{99} \mathrm{Tc}-\mathrm{NMR}$ active compounds such as the $\mathrm{Tc}(\mathrm{I})\left[\mathrm{Tc}(\mathrm{CO})_{3}\right]^{+}$species, as they exhibit distinctly different spectra sensitive to the nature of the coordinating ligands. Observed ${ }^{99} \mathrm{Tc}-\mathrm{NMR}$ spectral profiles are described in Figure 2.15 and Table 2.11. Our NMR analysis based on the ${ }^{99} \mathrm{Tc}$ nucleus revealed important information on the hydrolysis behavior of the $\left[\mathrm{Tc}(\mathrm{CO})_{3}\left(\mathrm{H}_{2} \mathrm{O}\right)_{3}\right]^{+}$ion. 


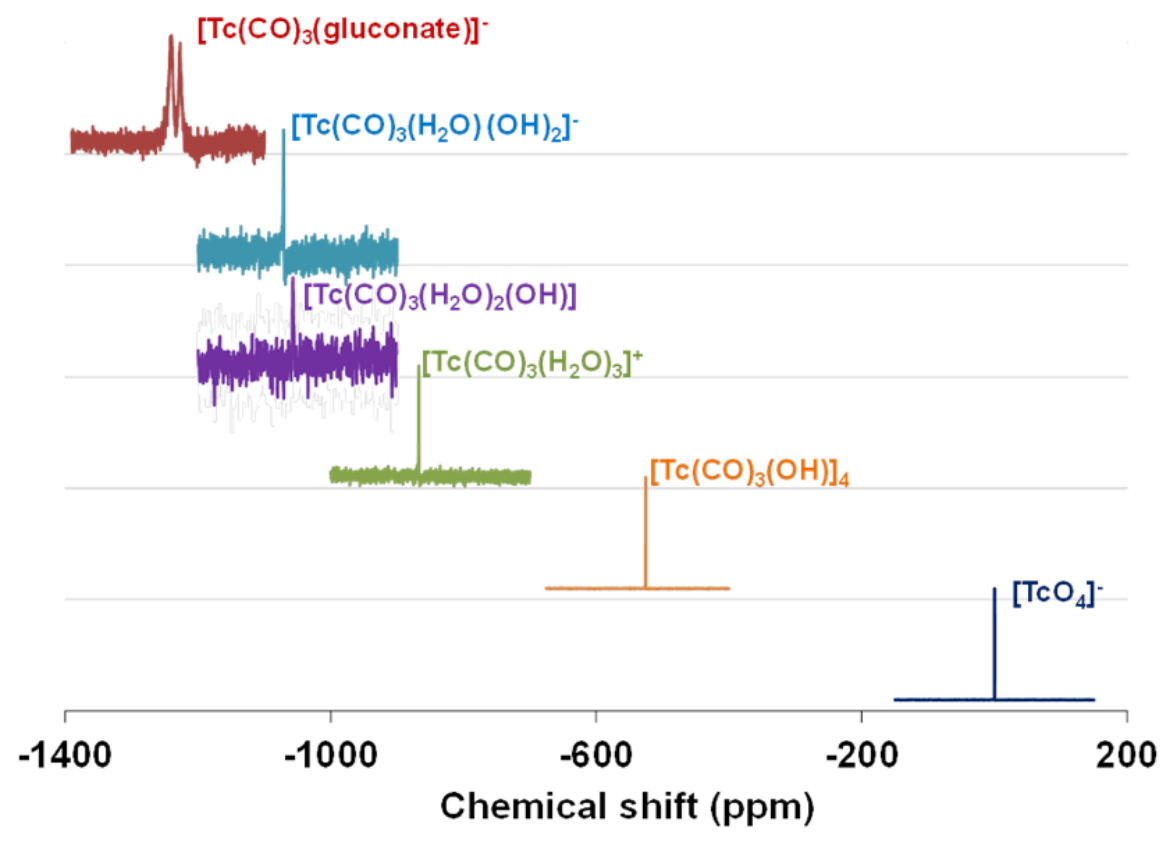

Figure 2.15. Overlay of ${ }^{99} \mathrm{Tc}-\mathrm{NMR}$ Resonances Observed for the Studied Tc Compounds

Table 2.11. Summary of $\left[\mathrm{Tc}(\mathrm{CO})_{3}\right]^{+}$Speciation by ${ }^{99} \mathrm{Tc}-\mathrm{NMR}$ Spectroscopy

\begin{tabular}{|c|c|c|c|}
\hline Species & Chemical Shift $(\mathbf{p p m})$ & Average Half-width & Stable pH Range \\
\hline $\mathbf{T c O}_{\mathbf{4}}^{-}$ & 0 & 40 & No dependence \\
\hline$\left[\mathbf{T c}(\mathbf{C O})_{3}\left(\mathbf{H}_{\mathbf{2}} \mathbf{O}\right)_{3}\right]^{+}$ & -869 & 80 & $1-7$ \\
\hline$\left[\mathbf{T c}(\mathbf{C O})_{3}(\mathbf{O H})\left(\mathbf{H}_{2} \mathbf{O}\right)_{2}\right]$ & -1060 & 90 & $<7$ \\
\hline$\left[\mathbf{T c}(\mathbf{C O})_{3}(\mathbf{O H})_{\mathbf{2}}\left(\mathbf{H}_{2} \mathbf{O}\right)\right]^{-}$ & -1146 & 100 & {$\left[\mathrm{OH}^{-}\right]>2 \mathrm{M}$} \\
\hline$\left[\mathbf{T c}(\mathbf{C O})_{3}(\mathbf{O H})_{3}\right]^{2-}$ & -1482 & 25 & {$\left[\mathrm{OH}^{-}\right]>2 \mathrm{M}$} \\
\hline$\left[\mathbf{T c}(\mathbf{C O})_{3}(\mathbf{O H})\right]_{4}$ & -585 & 250 & $7-8$ \\
\hline$\left[\mathbf{T c}(\mathbf{C O})_{4}\left(\mathbf{H}_{2} \mathbf{O}\right)_{2}\right]^{+}$ & -901 & 70 & $4-8$ \\
\hline$\left[\mathbf{T c}(\mathbf{C O})_{3}(\mathbf{g l u c o n a t e})\right]^{2-}$ & $-1230,-1247$ & 270,300 & {$\left[\mathrm{OH}^{-}\right]>0.1 \mathrm{M}$} \\
\hline
\end{tabular}

To summarize, it was observed that the $\left[\mathrm{Tc}(\mathrm{CO})_{3}\left(\mathrm{H}_{2} \mathrm{O}\right)_{3}\right]^{+}$ion can exist only in acidic aqueous solutions and undergoes extensive hydrolysis starting at $\sim \mathrm{pH} 6.8$. Based on the preliminary titration results, the first $\mathrm{p} K_{\mathrm{a}}$ of the $\left[\mathrm{Tc}(\mathrm{CO})_{3}\left(\mathrm{H}_{2} \mathrm{O}\right)_{3}\right]^{+}$complex was measured at 7.75. These results are in agreement with earlier literature reports. Gorshkov et al. (2000) studied $\left[\mathrm{Tc}(\mathrm{CO})_{3}\left(\mathrm{H}_{2} \mathrm{O}\right)_{3}\right]^{+}$hydrolytic behavior by potentiometric titration and observed an initial hydrolysis at $\mathrm{pH}$ of 5.8 to 6 . Alberto et al. (1999) estimated the $\mathrm{p} K_{\mathrm{a}}$ of the $\left[\mathrm{Tc}(\mathrm{CO})_{3}\left(\mathrm{H}_{2} \mathrm{O}\right)_{3}\right]^{+}$complex to be about 8.5.

The mono-hydrolyzed $\left[\mathrm{Tc}(\mathrm{CO})_{3}(\mathrm{OH})\left(\mathrm{H}_{2} \mathrm{O}\right)_{2}\right]$ species was observed to undergo oligomerization readily and to form the poly-nuclear compound $\left[\mathrm{Tc}(\mathrm{CO})_{3}(\mathrm{OH})\right]_{4}(\mathrm{Gorshkov}$ et al. 2000; Alberto et al. $1998 \mathrm{c})$. In this work we observed preferential formation of $\left[\mathrm{Tc}(\mathrm{CO})_{3}(\mathrm{OH})_{4}\right.$ tetramer in the $\mathrm{pH}$ range of 6.8 to 7.8. In addition, a relatively slow conversion of $\left[\mathrm{Tc}(\mathrm{CO})_{3}(\mathrm{OH})\left(\mathrm{H}_{2} \mathrm{O}\right)_{2}\right]$ to $\left[\mathrm{Tc}(\mathrm{CO})_{3}(\mathrm{OH})\right]_{4}$ was observed under mildly alkaline conditions. At higher $\mathrm{pHs}$, only the mono-hydroxo species persist in solution and at a $\mathrm{pH}$ of 13 and above no tetramer was detected. 
In the NMR titration experiment, the starting concentration of the purified $\left[\mathrm{Tc}(\mathrm{CO})_{3}\left(\mathrm{H}_{2} \mathrm{O}\right)_{3}\right]^{+}$complex obtained by the diglyme synthetic procedure was about $1.1 \mathrm{mM}$. This concentration was gradually reduced upon the addition of $\mathrm{NaOH}$ and the increase of the solution volume (Tables 2.4 and 2.5). No precipitate formation was observed in the entire $\mathrm{pH}$ range, consistent with the report by Gorshkov et al. (2000), who estimated the aqueous solubility of $\left[\mathrm{Tc}(\mathrm{CO})_{3}(\mathrm{OH})\right]_{4}$ tetramer to be $2 \mathrm{mM}$. However, experimental observations made during the aqueous synthesis of the $\left[\operatorname{Tc}(\mathrm{CO})_{3}\right]^{+}$indicate significantly smaller solubility of the mono-hydroxo species, even in the presence of borohydride reductant. It is estimated that the upper limit of the ${ }^{99} \mathrm{Tc}$ concentration in all samples generated during the aqueous synthesis and analyzed by NMR is $0.05 \mathrm{mM}$. The observed solubility data discrepancy using purified $\left[\mathrm{Tc}(\mathrm{CO})_{3}\right]^{+}$product and aqueous reaction mixture is speculatively attributed to the presence of multiple reduction products in the latter and continuous generation of insoluble $\mathrm{TcO}_{2}$. This conclusion is in part supported by the formation of the dark grey precipitate during the aqueous $\left[\mathrm{Tc}(\mathrm{CO})_{3}\right]^{+}$synthesis using borohydride reductant in presence of $\mathrm{CO}$, the result of $\mathrm{TcO}_{4}^{-}$reduction to $\mathrm{Tc}(\mathrm{IV})$, which precipitates as $\mathrm{TcO}_{2}$. This may be accompanied by precipitation of any hydrolyzed $\left[\mathrm{Tc}(\mathrm{CO})_{3}(\mathrm{OH})\right]_{4}$ oligomers present.

Inter-conversion of these and other species as the aqueous solution has been demonstrated. Interestingly, highly alkaline conditions $\left(\left[\mathrm{OH}^{-}\right]>1.5 \mathrm{M}\right)$ favor more highly soluble Tc(I) or Tc(IV) species, possibly due to formation of higher-order, monomeric, hydroxo complexes. Additional studies will be needed to achieve better understanding of the factors that influence Tc solubility in alkaline solutions.

In agreement with the report by Gorshkov et al. (2000), which postulated the second hydrolysis product $\left[\mathrm{Tc}(\mathrm{CO})_{3}(\mathrm{OH})_{2}\left(\mathrm{H}_{2} \mathrm{O}\right)\right]^{-}$in the highly alkaline solution with $\left[\mathrm{OH}^{-}\right]>1.5 \mathrm{M}$, we have identified this product in the solution at $\left[\mathrm{OH}^{-}\right]=1.8 \mathrm{M}$. The first hydrolysis $\left[\mathrm{Tc}(\mathrm{CO})_{3}(\mathrm{OH})\left(\mathrm{H}_{2} \mathrm{O}\right)_{2}\right]$ species persists in this alkaline solution as well. In addition, a third product was revealed that exhibits a ${ }^{99} \mathrm{Tc}$ resonance at $-1482 \mathrm{ppm}$. A literature search revealed no information as to the possible nature of this product. We speculate this could be due in part to the fact that our NMR measurements were performed using a frequency window outside the range used previously, thus allowing for the detection of a signal that exists beyond previously analyzed frequencies. We hypothesize that, based on the very narrow half-width of this band, the frequency we observed corresponds to the third hydrolysis species $\left[\operatorname{Tc}(\mathrm{CO})_{3}(\mathrm{OH})_{3}\right]^{2-}$ and possesses a highly symmetrical structure. Additional studies will be needed to identify the compositions of these species.

This work demonstrated the formation of the $\left[\mathrm{Tc}(\mathrm{CO})_{3}(\text { gluconate })\right]^{2-}$ complex in alkaline solution. Initial mixing of $\left[\mathrm{Tc}(\mathrm{CO})_{3}\left(\mathrm{H}_{2} \mathrm{O}\right)_{3}\right]^{+}$and potassium gluconate/ $\mathrm{NaOH}$ solutions generates both $\left[\mathrm{Tc}(\mathrm{CO})_{3}(\mathrm{OH})\left(\mathrm{H}_{2} \mathrm{O}\right)_{2}\right]$ and $\left[\mathrm{Tc}(\mathrm{CO})_{3}\right.$ (gluconate $\left.)\right]^{2-}$ complexes, with the former quickly converting to the Tc(I) tricarbonyl gluconate complex and pertechnetate. Similar behavior has been observed by Lukens et al. (2004). In our study, the ${ }^{99} \mathrm{Tc}-\mathrm{NMR}$ spectrum of $\left[\mathrm{Tc}(\mathrm{CO})_{3} \text { (gluconate) }\right]^{2-}$ is characterized by the presence of two bands at -1230 and $-1247 \mathrm{ppm}$ with corresponding half-widths of 270 and $300 \mathrm{~Hz}$. This observation may be consistent with Lukens et al. (2004), which reported that the $\left[\operatorname{Tc}(\mathrm{CO})_{3}(\text { gluconate })\right]^{2-}$ complex had a single broad ${ }^{99} \mathrm{Tc}$ resonance at $-1239 \mathrm{ppm}$ and a half-width of $650 \mathrm{~Hz}$. We suggest that the broad ${ }^{99} \mathrm{Tc}$ resonance previously reported was in fact an unresolved doublet, which could not be resolved with the 90-megahertz instrument used in that experiment. Presence of two ${ }^{99} \mathrm{Tc}$ resonances suggests the existence of two non-equivalent Tc(I)-gluconate species. 
Our initial month-long, solution-monitoring studies indicated only limited (but varying) stability in aerated solution for all tested species. Over this time frame, $53 \%\left[\mathrm{Tc}(\mathrm{CO})_{3}\left(\mathrm{H}_{2} \mathrm{O}\right)_{3}\right]^{+}, 21 \%$ $\left[\mathrm{Tc}(\mathrm{CO})_{3}(\mathrm{OH})\left(\mathrm{H}_{2} \mathrm{O}\right)_{2}\right]$, and $30 \%\left[\mathrm{Tc}(\mathrm{CO})_{3}(\text { gluconate })\right]^{2-}$ were re-oxidized to $\mathrm{TcO}_{4}{ }^{-}$.

This experimental study has led to several important conclusions, which are summarized below.

- $\quad\left[\mathrm{Tc}(\mathrm{CO})_{3}\left(\mathrm{H}_{2} \mathrm{O}\right)_{3}\right]^{+}$complex ion exists only in acidic solutions and undergoes extensive hydrolysis starting at about $\mathrm{pH}$ 6.8. The first $\mathrm{p} K_{\mathrm{a}}$ of the $\left[\mathrm{Tc}(\mathrm{CO})_{3}\left(\mathrm{H}_{2} \mathrm{O}\right)_{3}\right]^{+}$complex was obtained to be 7.75. Similar hydrolytic behavior can be anticipated in the alkaline tank waste. Therefore the presence of the $\left[\mathrm{Tc}(\mathrm{CO})_{3}\left(\mathrm{H}_{2} \mathrm{O}\right)_{3}\right]^{+}$itself in the alkaline waste is not viable. Rather its hydrolysis products, of general composition $\left[\mathrm{Tc}(\mathrm{CO})_{3}(\mathrm{OH})_{n}\left(\mathrm{H}_{2} \mathrm{O}\right)_{m}\right]^{1-n}$ in the absence of complexing agents, are anticipated to exist in the alkaline waste.

- The complexation studies of the organic ligands found in the tank waste with $\left[\operatorname{Tc}(\mathrm{CO})_{3}\left(\mathrm{H}_{2} \mathrm{O}\right)_{3}\right]^{+}$is limited to the acidic solutions, which is not directly applicable to the tank waste chemistry. Under the alkaline conditions, such complexation studies are complicated by the hydrolysis of $\left[\mathrm{Tc}(\mathrm{CO})_{3}\left(\mathrm{H}_{2} \mathrm{O}\right)_{3}\right]^{+}$and formation of the multiple $\left[\mathrm{Tc}(\mathrm{CO})_{3}(\mathrm{OH})_{\mathrm{n}}\left(\mathrm{H}_{2} \mathrm{O}\right)_{\mathrm{m}}\right]^{1-\mathrm{n}}$ species. We feel that a prerequisite thorough understanding of $\left[\mathrm{Tc}(\mathrm{CO})_{3}\left(\mathrm{H}_{2} \mathrm{O}\right)_{3}\right]^{+}$hydrolytic behavior and speciation, as well as quantification of the hydrolysis constants, is necessary to properly evaluate the role of alkaline-soluble low-valence Tc in Hanford tank wastes. This conclusion is supported by previous reports demonstrating that hydrolysis of the $\left[\mathrm{Tc}(\mathrm{CO})_{3}\left(\mathrm{H}_{2} \mathrm{O}\right)_{3}\right]^{+}$ion interferes with complexation to not only the weakly coordinating halide ligands but also to stronger ligands such as cyanate and thiocyanate (Gorshkov et al. 2003).

- It is estimated that the upper limit of the ${ }^{99} \mathrm{Tc}$ - concentration in the aqueous samples containing $\mathrm{Tc}$ in multiple oxidation states is $0.05 \mathrm{mM}$, comparable to or exceeding that found in the liquid tank waste samples, thus the obtained information cannot be disqualified as relevant to the in-tank conditions. It is significant that the high hydroxide concentration elevates the solubility of the non-pertechnetate species in the aqueous solution even without organic ligands present. This result emphasizes the importance of understanding the $\mathrm{OH}^{-}$ion coordination with non-pertechnetate $\mathrm{Tc}$ in the lower than VII oxidation states.

\subsection{Microcalorimeter Performance Testing using Complexation of $\mathrm{BaCl}_{2}$ by the Macrocyclic Ligand 18-Crown-6}

One of the tasks for this project in FY 2013 was to purchase a microcalorimeter suitable for work in measuring the complexation energies for the binding of Tc(I) tricarbonyl fragments to organic and inorganic ligands commonly found in Hanford tank supernatants. This section summarizes the purchase, installation, and developmental work performed in FY 2013 related to this goal.

\subsubsection{Introduction}

The Gibbs free energy $(\Delta \mathrm{G}=-\mathrm{RT} \operatorname{lnK})$, where $\mathrm{K}$ is the equilibrium constant, and enthalpy $(\Delta \mathrm{H})$ and entropy $(\Delta S)$ are fundamental thermodynamic parameters that provide insight into the binding strength, complexation energies, the effect of solvation, and the nature of ligand to metal binding. A number of techniques are available to determine such equilibrium constants, including potentiometry, distribution methods (such as solvent extraction and ion exchange), solubility measurements, and a variety of 
spectroscopic methods (UV-Vis, NMR, fluorescence). If equilibrium constants are determined at variable temperatures, an average enthalpy can be obtained by using the van't Hoff equation under the assumption of a constant enthalpy for the selected temperature range. However, in many cases the enthalpy of complexation is found to be temperature-dependent (Rao 2011 and references therein). Therefore, a direct measurement of the enthalpy of complexation becomes important and calorimetry is the technique of choice for these cases. In this project, calorimetry is intended to be used for determination of thermodynamic parameters of $\mathrm{Tc}^{\mathrm{I}}(\mathrm{CO})_{3}{ }^{+}$binding with ligands occurring in non-pertechnetate-containing Hanford tank supernates.

One or several standard reactions are necessary to test the accuracy of a calorimeter. According to Buschmann and Schollmeyer (1999), a number of requirements are important for a reaction to be used for this purpose: a) availability of all reactants in a pure form; b) no reactivity of these chemicals with standard atmospheric constituents $\left(\mathrm{CO}_{2}\right.$, oxygen, etc.); and c) ease of drying and weighing of chemicals under ambient atmospheric conditions. Historically, the protonation reaction of the strong base trishydroxy methyl aminomethane by hydrochloric acid was used as a calibration reference (see references in Table 1 of Buschmann and Schollmeyer (1999)). However, application of this reaction produces only one thermodynamic parameter, namely the protonation enthalpy for this process. Application of a complexation reaction between synthetic host molecules and alkaline earth metal cations, as proposed by Izatt and coworkers about 45 years ago (Izatt et al. 1969), is now considered a more reliable way to test performance and accuracy of modern calorimeters because data processing of titration curves allows simultaneous calculation both of stability constants and reaction enthalpies. The best pair of candidate reagents for this testing should feature a magnitude of the complexation constant of 100 to $10000 \mathrm{M}^{-1}$, with the value of the reaction enthalpy being as high as possible. From this point of view, the complexation reaction between 18-crown-6 ether and a salt of barium appears to be the most suitable for use as a test reaction. The simplicity of this reaction includes the formation of only a 1:1 complex and the absence of any protonation effects for the ligand (which otherwise might cause some problems with reproducibility of the measured values).

In isothermal titration calorimetry, the heat is measured for the incremental injection of one reactant (the titrant) into a reaction vessel (or ampoule) containing the other reactant (the titrate). The data thus form a titration curve of heat vs. the extent of the reaction, the analysis of which yields $\Delta \mathrm{H}_{\text {cal }}$ (the calorimetric reaction enthalpy) and the equilibrium constant $\mathrm{K}$. If this calorimetric titration experiment can be performed over a range of temperatures, then $\Delta \mathrm{H}_{\mathrm{cal}}$ and $\mathrm{K}$ for a number of temperatures can be measured. The latter can be further analyzed using the van't Hoff relation ( $\mathrm{d} \operatorname{lnK} / \mathrm{dT}=\Delta \mathrm{H} /\left(\mathrm{RT}^{2}\right)$ to yield a second estimate of $\Delta \mathrm{H}$ for the reaction (van't Hoff, $\Delta \mathrm{H}_{\mathrm{vH}}$ ).

In the work described here, all the testing was performed at $25^{\circ} \mathrm{C}$ only, so it was not possible to derive $\Delta \mathrm{H}_{\mathrm{vH}}$ from the data obtained, but an attempt was made to correct the titration curve data for any heat of dilution of the titrate $\left(\mathrm{BaCl}_{2}\right)$ by titrating it into a blank solution (DI water) in order to obtain a true value of $\Delta \mathrm{H}_{\text {cal }}$, which in theory should agree with $\Delta \mathrm{H}_{\mathrm{vH}}$ within the uncertainty limits associated with these two estimates of the same thermodynamic parameter. 


\subsubsection{Experimental}

\subsubsection{Instrument Description}

A TAM III series microcalorimeter from TA Instruments - Waters LLC was installed and put into operation in June 2013. During installation, a microcalorimetry service specialist successfully conducted a general performance test (which required no injection and stirring), but a first round of testing in a titration mode with $0.85 \mathrm{ml}$ of 5-mM 18 -crown- 6 and $95 \mathrm{mM} \mathrm{BaCl}_{2}$ produced a very noisy and positively biased baseline signal that obscured heat generation peaks even at relatively high concentrations of the reacting components. The problem was solved after departure of the installation specialist by performing a careful adjustment of the mixing propeller's vertical position within the inner space of an ampoule.

Figure 2.16 shows a general view and some details of titration assemblies and their components. This picture does not include the entire instrument, with both sample and blank titration assemblies inserted into their thermostated bath openings, as it would hide all details except the upper section of both assemblies to an observer.

a

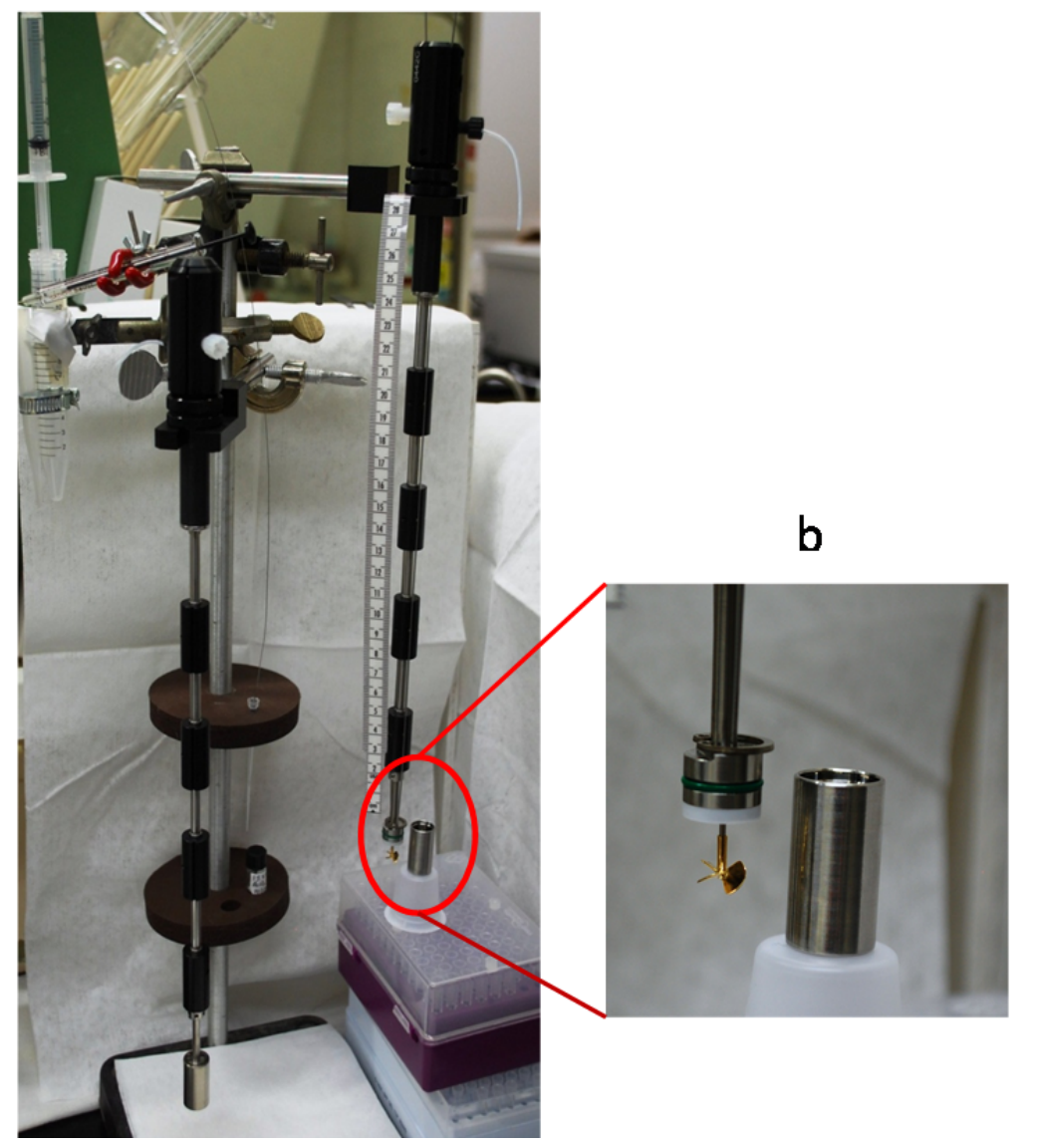

C

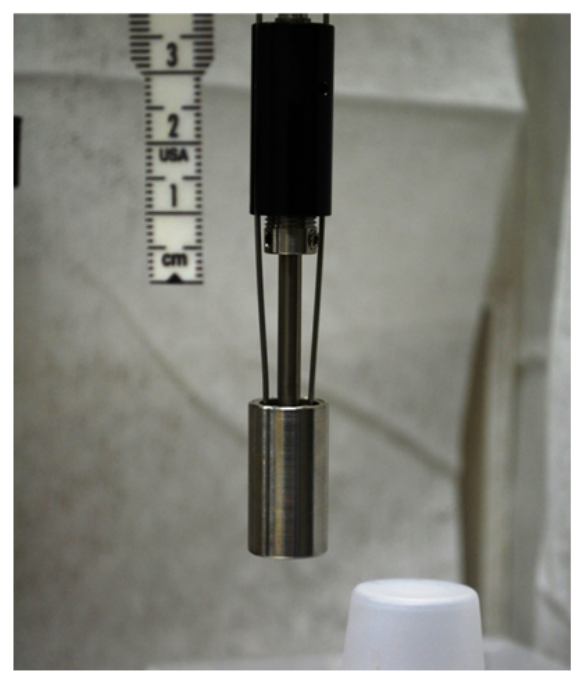

Figure 2.16. Microcalorimetric Titration Vessel Setup: a) General View of Blank Assembly (left) and Sample Assembly (right) with Ampoule Removed from the Propeller Shaft; b) Close Up of Ampoule Positioned Next to Propeller Shaft; c) Ampoule Assembled with Propeller Shaft and Injection Capillary Line. A graduated ruler in pictures a) and c) is shown for a better size perception of entire assembly and the ampoule part. 


\subsubsection{Microcalorimetric Titration Details}

Per the manufacturer's instructions for a typical titration experiment, the volume of titrant (the ligand) loaded into the ampoule was set at $0.85 \mathrm{ml}$ and intensity of mixing was set at 70 rotations per minute. A $0.25 \mathrm{ml}$ capacity syringe was carefully loaded with the titrate (a solution of barium salt) and was installed into a digital syringe pump receptacle with capillary tubing inserted almost all the way into the titrate delivery channel of the titration assembly, but just a few millimeters above the solution level in the ampoule. A blank titration assembly was prepared in a similar way, but had no stirring motor and injection line applied to its upper section. Both assemblies were slowly and synchronously loaded into the respective channels, which lead to the thermostat space of the instrument and were thermally equilibrated for at least one hour before sliding the injection capillary all the way down to get its end immersed 2-3 $\mathrm{mm}$ deep into the titrant solution.

This step was followed by another waiting period of 20-30 minutes (to ensure that the baseline signal magnitude was of low intensity and its slope less than $\sim 300-400 \mathrm{nW} / \mathrm{hr}$ ) before starting the titration experiment. During this final waiting period, the syringe pump was programmed with the following parameters: injection volume, number of injections, and time between injections. Also, the instrument was programmed to perform (or to use previously obtained data for) a dynamic correction calibration before starting the actual titration run (see more details about the dynamic correction mode of operation of a titration calorimeter in Bäckmann et al. 1994).

\subsubsection{Reagents}

18-crown-6 purification. The ligand used in this project was purified by recrystallization of commercially available compound (99\% purity, Aldrich) from acetonitrile following the standard procedures (Gokel et al. 1974; Perrin and Armarego 1988). Drying to remove residual solvent was performed at elevated temperature $\left(42-65^{\circ} \mathrm{C}\right)$ under an inert gas flow. Due to the temperature instability of the heating device, melting of initially present, well-formed crystals of 18 -crown- 6 occurred and this melt contacted the bottom and walls of the glass vial for several hours. A stock solution of 18-crown-6 $(5.00 \mathrm{mM})$ was prepared by dissolution of a pre-weighed amount of the solidified compound in a known volume of water.

Determination of $\mathrm{Ba}^{2+}$ concentration in a stock solution of $\mathbf{B a C l}_{2}$. A stock solution comprised of $0.193 \mathrm{BaCl}_{2}$ was available from a project conducted in 2010. No records from the 2010 work were available; however, the barium concentration in that stock solution was verified by a standard method. To determine the exact concentration of $\mathrm{Ba}$, a gravimetric technique based on precipitation of $\mathrm{Ba}$ as sparingly soluble barium chromate (Vogel and Jeffery 1989, page 474) followed by separation, washing, and drying of the precipitate at $120^{\circ} \mathrm{C}$ was used. This determination resulted in $0.181_{6} \mathrm{M}_{\text {concentration }}$ of $\mathrm{BaCl}_{2}(6 \%$ less than the value on the label). The concentration found was confirmed later to be in good agreement with refined value of $\mathrm{C}_{\mathrm{BaCl}}$ based on data processing of multiple complexation thermograms with an "unlocked" concentration of the titrant specified (data processing mode \#4, Section 2.7.2.4).

\subsubsection{Data Processing}

Each titration experiment was performed four times under the same experimental conditions (initial volume and concentration of titrant, concentration of $\mathrm{BaCl}_{2}$ in a syringe, volume per injection, number of injections, etc.). Data processing was performed using the built in "Analysis" function, which offers 
many options for calculating a ligand binding assessment. In this work we processed the data from each titration run in five different ways as listed below:

1. All data points with both the ligand and metal concentrations locked

2. Data points from second to the last addition of the titrant (exclusion of the first injection) with both the ligand and metal concentration locked

3. All data points with metal concentration locked while the ligand concentration was set as a variable parameter

4. All data points with the ligand concentration locked while the metal concentration was set as a variable parameter

5. All data points with the ligand and metal concentrations locked at values optimized at the data processing steps 3 and 4 , respectively.

These five modes of data processing were applied first to the complexation titration experiment only (no correction for the heat of dilution data from the $\mathrm{BaCl}_{2}$ injection into water; Tables 2.12 and 2.14). At the next round of data processing, heats of dilution were applied to the complexation titration data set and refinement was repeated with all five modes of data processing listed above (Tables 2.13 and 2.15).

\subsubsection{Results}

Typical thermograms for two titration experiments at higher and lower titrate and titrant concentrations are shown in Figure 2.17/2.17a and Figure 2.18/2.18a. (Each series was replicated four times, but one titration at a lower concentration of titrate suffered a significant disturbance of baseline in the middle of titration, which severely affected thermal peak magnitudes. That particular run was not used for a full-scale data processing and refinement of $\Delta \mathrm{H}$ and $\mathrm{K}$.) 
PNNL-22957

EMSP-RPT-018

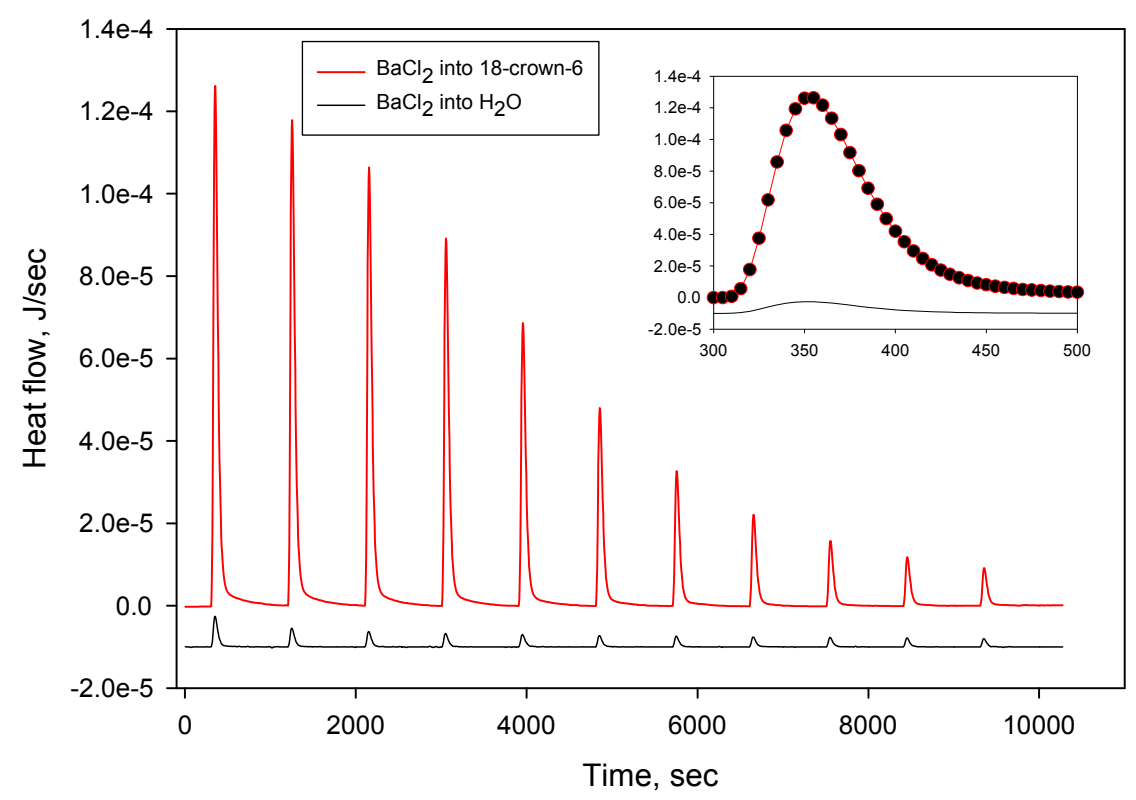

Figure 2.17. Microcalorimetric Titration Experiment at Higher Concentrations of Reactants. Titration of $16.785 \mathrm{mM} \mathrm{BaCl}_{2}$ (11 injections with $18.7 \mu 1$ of $\mathrm{BaCl}_{2}$ per injection) into $0.85 \mathrm{ml}$ of $1.97 \mathrm{mM}$ of 18 -crown-6. Black trace shows records of baseline experiment (titration of $\mathrm{BaCl}_{2}$ into water). Inset shows expansion of the first peak region (every seventh injection point is shown for simplicity). 
Ligand Binding Report

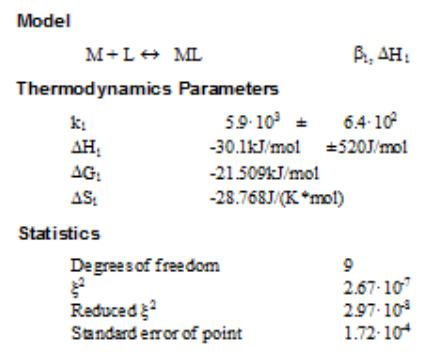

Input Data

Volume in veset Volume in vessel Number of datapoints
Concentration of $[\mathrm{L}]$ in vessel
Concentration of $[\mathrm{M}]$ in syring

$\begin{array}{ccccc}\text { No } & \begin{array}{c}\text { Volume } \\ (\mu 1)\end{array} & \begin{array}{c}\text { Qes } \\ (\mathrm{mJ})\end{array} & \begin{array}{c}\text { Qeser } \\ (\mathrm{mJ})\end{array} & \begin{array}{c}\text { Residual } \\ (\mathrm{m})\end{array} \\ 1 & 18.7 & 8.83 & 8.53 & 0.30 \\ 2 & 18.7 & 8.20 & 8.10 & 0.11 \\ 3 & 18.7 & 7.43 & 7.43 & 0.00 \\ 4 & 18.7 & 6.28 & 6.42 & -0.14 \\ 5 & 18.7 & 4.88 & 5.09 & -0.20 \\ 6 & 18.7 & 3.42 & 3.67 & -0.25 \\ 7 & 18.7 & 2.35 & 2.51 & -0.16 \\ 8 & 18.7 & 1.58 & 1.69 & -0.11 \\ 9 & 18.7 & 1.14 & 1.17 & -0.03 \\ 10 & 18.7 & 0.84 & 0.84 & 0.00 \\ 11 & 18.7 & 0.64 & 0.62 & 0.02\end{array}$

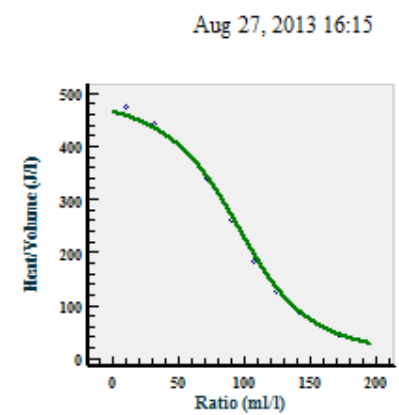

Aug 27, $201316: 15$

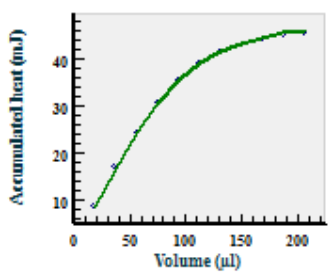

Figure 2.17a: Example of Data Fitting and Refinement of Thermodynamic Constants $(\Delta \mathrm{H}$ and equilibrium constant) for Experimental Data Shown in Figure 2.17. Both ligand and metal concentrations for this refinement are locked at their experimentally determined levels (Data Processing Mode \#1).

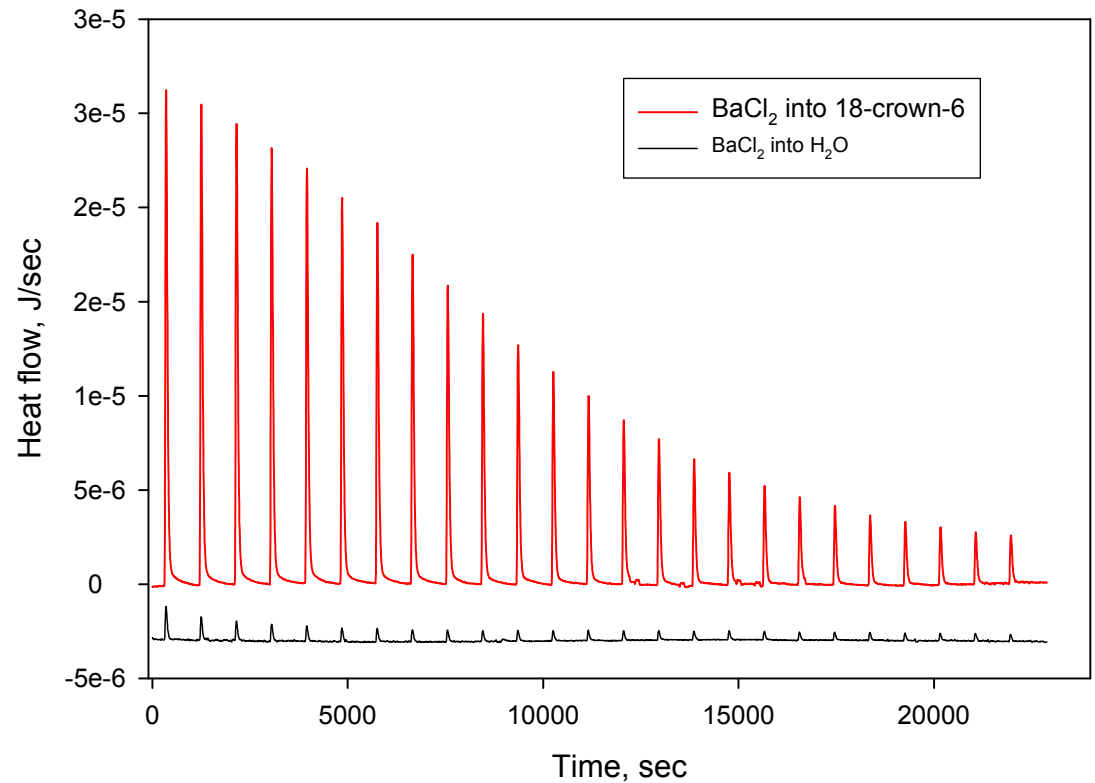

Figure 2.18. Microcalorimetric Titration Experiment at Lower Concentrations of Reactants. Titration of $8.516 \mathrm{mM} \mathrm{BaCl}_{2}$ (25 injections with $8.5 \mu \mathrm{l}$ of $\mathrm{BaCl}_{2}$ per injection) into $0.85 \mathrm{ml}$ of $0.9835 \mathrm{mM}$ of 18 -crown-6. Black trace shows records of baseline experiment (titration of $\mathrm{BaCl}_{2}$ into water). 
PNNL-22957

EMSP-RPT-018

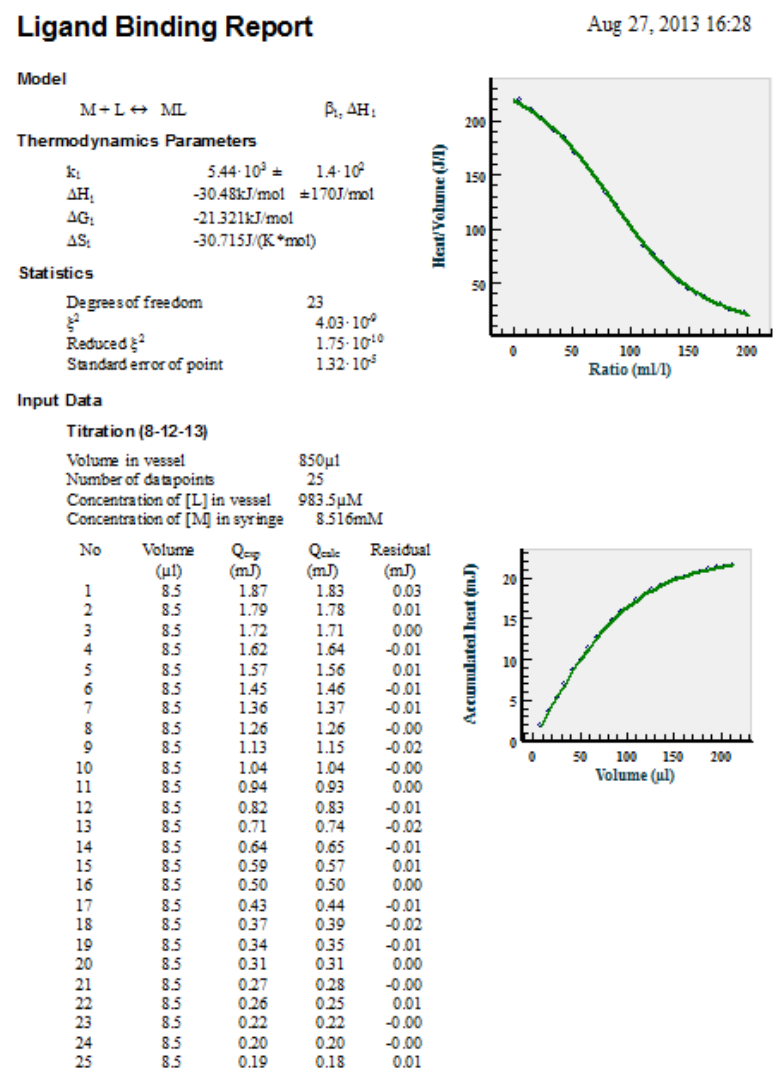

Figure 2.18a. Example of Data Fitting and Refinement of Thermodynamic Constants $(\Delta \mathrm{H}$ and equilibrium constant) for Experimental Data Shown in Figure 2.18. Both ligand and metal concentrations for this refinement are locked at their experimentally determined levels (Data Processing Mode \#1). 
Table 2.12. Summary of Results on $\Delta \mathrm{H}$ and $\mathrm{K}$ Determination from Calorimetric Titration of $8.516 \mathrm{mM} \mathrm{BaCl}_{2}$ (syringe) into $0.9835 \mathrm{mM} 18$-crown-6 (ampoule). No heat of dilution of $\mathrm{BaCl}_{2}$ into water applied before data processing. (See Section 2.7.2.4 for more details on various modes of data processing)

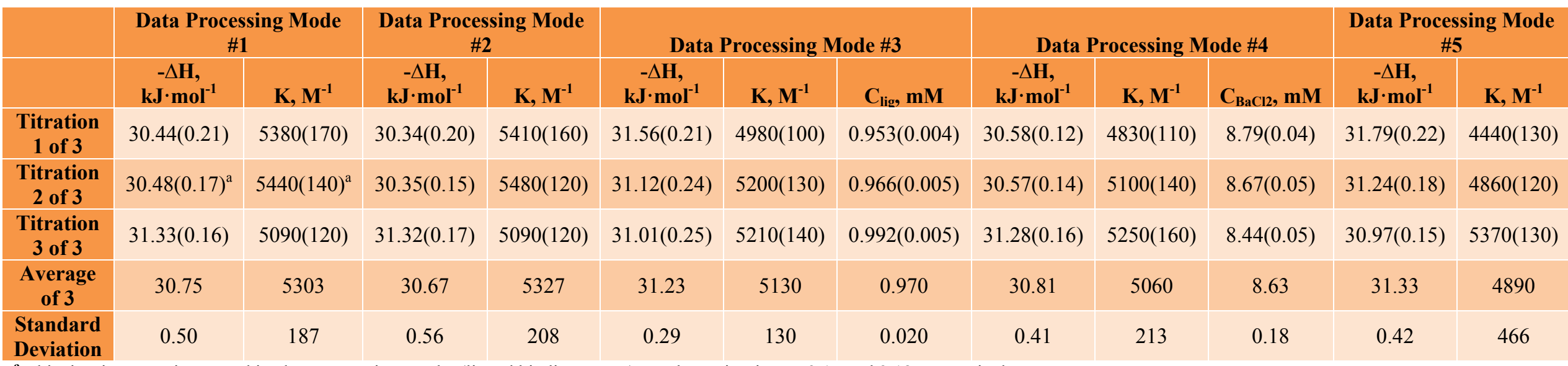

${ }^{\mathbf{a}}$ This titration experiment and its data processing results (ligand binding report) are shown in Figures 2.17 and 2.18, respectively.

Table 2.13. Summary of Results on $\Delta \mathrm{H}$ and $\mathrm{K}$ Determination from Calorimetric Titration of $8.516 \mathrm{mM} \mathrm{BaCl}_{2}$ into $0.9835 \mathrm{mM} 18$-crown-6 (ampoule). Heat of dilution of $\mathrm{BaCl}_{2}$ into water applied before data processing.

\begin{tabular}{|c|c|c|c|c|c|c|c|c|c|c|c|c|}
\hline & \multicolumn{2}{|c|}{$\begin{array}{c}\text { Data Processing Mode } \\
\text { \#1 }\end{array}$} & \multicolumn{2}{|c|}{$\begin{array}{c}\text { Data Processing Mode } \\
\# 2\end{array}$} & \multicolumn{3}{|c|}{ Data Processing Mode \#3 } & \multicolumn{3}{|c|}{ Data Processing Mode \#4 } & \multicolumn{2}{|c|}{$\begin{array}{c}\text { Data Processing Mode } \\
\# 5\end{array}$} \\
\hline & $\begin{array}{c}-\Delta \mathbf{H}, \\
\mathrm{kJ} \cdot \mathrm{mol}^{-1}\end{array}$ & $\mathbf{K}, \mathbf{M}^{-1}$ & $\begin{array}{c}-\Delta \mathbf{H}, \\
\mathbf{k J} \cdot \mathbf{m o l}^{-1}\end{array}$ & $\mathbf{K}, \mathbf{M}^{-1}$ & $\begin{array}{c}-\Delta \mathbf{H}, \\
\mathbf{k J} \cdot \mathbf{m o l}^{-1}\end{array}$ & $\mathbf{K}, \mathbf{M}^{-1}$ & $\mathrm{C}_{\text {ligg, }}, \mathbf{m M}$ & $\begin{array}{c}-\Delta \mathbf{H}, \\
\mathbf{k J} \cdot \mathbf{m o l}^{-1}\end{array}$ & $\mathbf{K}, \mathbf{M}^{-1}$ & $\mathrm{C}_{\mathrm{BaCl} 2}, \mathrm{mM}$ & $\begin{array}{c}-\Delta \mathbf{H}, \\
\mathbf{k J} \cdot \mathbf{m o l}^{-1}\end{array}$ & $\mathbf{K}, \mathbf{M}^{-1}$ \\
\hline $\begin{array}{c}\text { Titration } \\
1 \text { of } 3\end{array}$ & $28.46(0.16)$ & $6120(160)$ & $28.47(0.17)$ & $6120(170)$ & $29.10(0.19)$ & $5830(130)$ & $0.964(0.004)$ & $28.52(0.12)$ & $5710(140)$ & $8.69(0.04)$ & $29.19(0.16)$ & $5420(140)$ \\
\hline $\begin{array}{c}\text { Titration } \\
2 \text { of } 3\end{array}$ & $28.50(0.13)$ & $6200(140)$ & $28.48(0.14)$ & $6210(140)$ & $28.74(0.20)$ & $6080(150)$ & $0.976(0.005)$ & $28.52(0.13)$ & $6040(170)$ & $8.58(0.04)$ & $28.77(0.13)$ & $5920(130)$ \\
\hline $\begin{array}{c}\text { Titration } \\
3 \text { of } 3\end{array}$ & $29.29(0.16)$ & $5790(150)$ & $29.39(0.15)$ & $5760(160)$ & $28.69(0.18)$ & $6080(140)$ & $1.001(0.004)$ & $29.22(0.12)$ & $6190(160)$ & $8.36(0.04)$ & $28.66(0.15)$ & $6470(170)$ \\
\hline $\begin{array}{l}\text { Average } \\
\text { of } 3\end{array}$ & 28.75 & 6037 & 28.78 & 6030 & 28.84 & 6000 & 0.980 & 28.75 & 5980 & 8.54 & 28.87 & 5937 \\
\hline $\begin{array}{l}\text { Standard } \\
\text { Deviation }\end{array}$ & 0.47 & 217 & 0.53 & 240 & 0.22 & 144 & 0.019 & 0.40 & 246 & 0.17 & 0.28 & 525 \\
\hline
\end{tabular}


Table 2.14. Summary of Results on $\Delta \mathrm{H}$ and $\mathrm{K}$ Determination from Calorimetric Titration of $16.785 \mathrm{mM} \mathrm{BaCl}_{2}$ (syringe) into $1.970 \mathrm{mM} 18$-crown-6 (ampoule). No heat of dilution of $\mathrm{BaCl}_{2}$ is applied before data processing.

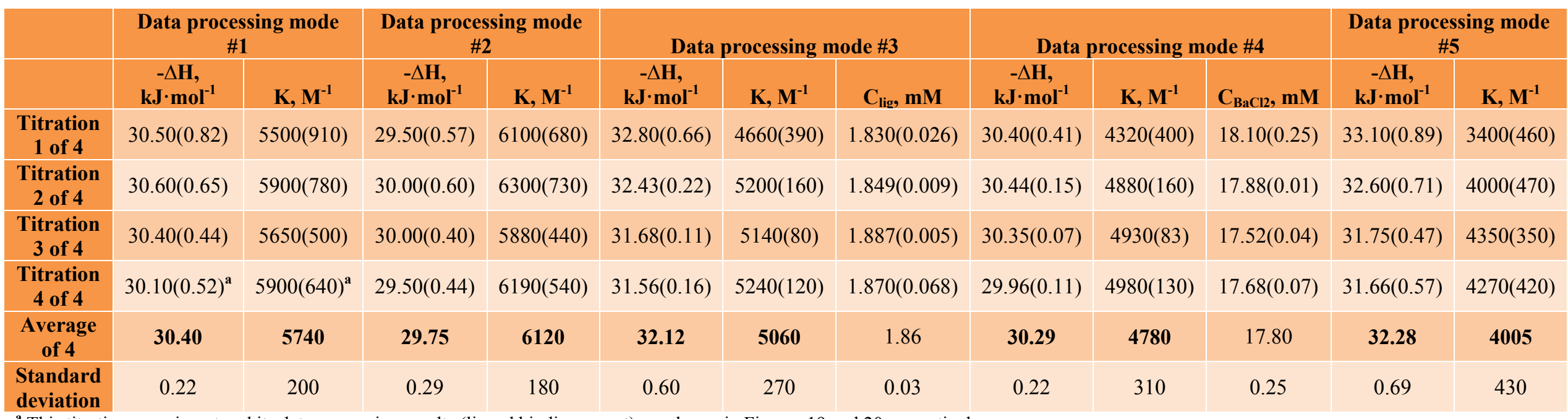

${ }^{\mathbf{a}}$ This titration experiment and its data processing results (ligand binding report) are shown in Figures 19 and 20 respectively.

Table 2.15. Summary of Results on $\Delta \mathrm{H}$ and $\mathrm{K}$ Determination from Calorimetric Titration of $16.785 \mathrm{mM} \mathrm{BaCl}_{2}$ into $1.970 \mathrm{mM} 18$-crown-6 (ampoule). Heat of dilution of $\mathrm{BaCl}_{2}$ is applied before data processing.

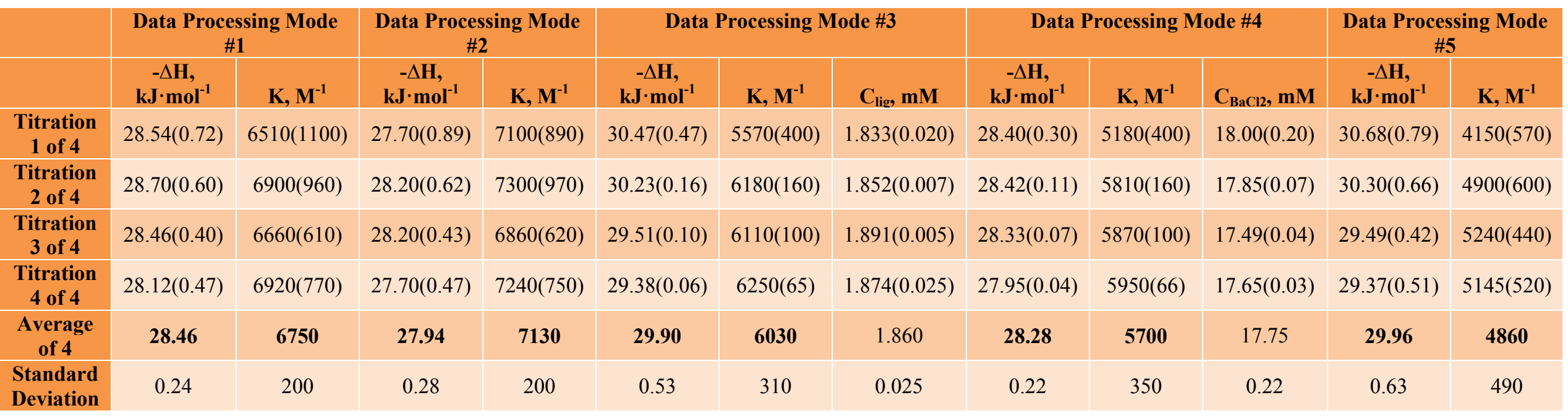




\subsubsection{Discussion}

Reagent concentrations and their mode of mixing (number of injections and injection volumes for titrations shown in Figure 2.17 were selected to reproduce an experiment reported by Mizoue and Tellinghuisen (Mizoue et al. 2004). These authors reported excellent reproducibility of $\Delta H$ $(-32.04 \pm 0.28 \mathrm{~kJ} / \mathrm{mol})$ and $\mathrm{K}\left(5560 \pm 100 \mathrm{M}^{-1}\right)$ values between seven runs conducted at $25^{\circ} \mathrm{C}$, while using only a modest variation in $\mathrm{C}_{\mathrm{BaCl} 2}^{0}$ and $\mathrm{C}_{\text {ligand }}^{0}$ between the runs. All their refinements were performed after subtracting the heat of dilution data (injections of $\mathrm{BaCl}_{2}$ into water) from the respective complexation thermograms. Unfortunately, they did not report $\Delta \mathrm{H}$ and $\mathrm{K}$ values from their thermograms before subtracting the blank data.

There are a number of studies of the same complexation reaction in which no explicit statement is made that the authors did obtain the blank dilution data and applied them to correct their complexation thermograms. In these papers somewhat lower values of $\Delta \mathrm{H}$ and $\mathrm{K}$ are reported:

$-31.5 \pm 1.2 \mathrm{~kJ} / \mathrm{mol}$, and 2630 to $4790 \mathrm{M}^{-1}$ (Buschman and Schollmeyer 1999)

$-31.42 \pm 0.04 \mathrm{~kJ} / \mathrm{mol}$, and $5140 \pm 40 \mathrm{M}^{-1}$ (Liu and Sturtevant 1995)

$-29.5 \pm 0.5 \mathrm{~kJ} / \mathrm{mol}$, and 5900 to $6760 \mathrm{M}^{-1}$ (Solov'ev et al. 1998).

Liu and coworkers also reported significant discrepancies between van't Hoff and calorimetric enthalpies for this complexation reaction $\left(\Delta \mathrm{H}_{\mathrm{cal}}=-31.42 \pm 0.04 \mathrm{~kJ} / \mathrm{mol} \mathrm{vs.} \Delta \mathrm{H}_{\mathrm{vH}}=28.07 \mathrm{~kJ} / \mathrm{mol}\right)$. Almost the same magnitude of discrepancy is noted by Mizoue and Tellinghuisen $\left(\Delta \mathrm{H}_{\mathrm{cal}}=-32.04 \pm 0.28 \mathrm{~kJ} / \mathrm{mol}\right.$ vs. $\left.\Delta \mathrm{H}_{\mathrm{vH}}=-(28.3+30.0) / 2=-29.15 \pm 0.85 \mathrm{~kJ} / \mathrm{mol}\right)$.

The results of our data processing (with titration conditions similar to those of Mizoue and Tellinghuisen) returned the following values of $\Delta \mathrm{H}$ and $\mathrm{K}$ (average of four replicates, with averaging the values refined by all five data processing modes within each replicate):

$-31.0 \pm 1.2 \mathrm{~kJ} / \mathrm{mol}$, and $5140 \pm 830 \mathrm{M}^{-1}$ (based on uncorrected complexation thermograms) $-28.91 \pm 0.95 / \mathrm{mol}$, and $6100 \pm 890 \mathrm{M}^{-1}$ (using dilution heat corrected complexation thermograms).

It is apparent that our set of uncorrected values of $\Delta \mathrm{H}$ and $\mathrm{K}$ is in good agreement with the three sources of literature data discussed above, when no correction for heat of dilution of $\mathrm{BaCl}_{2}$ was reported. On the other hand, our dilution heat-corrected value of $\Delta \mathrm{H}$ is 2 to $8 \%$ lower than the above-mentioned values and $10 \%$ lower compared with the clearly confirmed, dilution heat-corrected estimate of enthalpy at $32.04 \mathrm{~kJ} / \mathrm{mol}$ (Mizoue and Tellinghuisen 2004). But at the same time, our dilution heat-corrected value of the reaction enthalpy is in very good agreement with van't Hoff data for this complexation reaction.

We also tried to compare our microcalorimetric titration results with the instrument manufacturer's data on the same complexation reaction. That experiment was performed in 2008 and most likely not exactly same instrument model was used at that time compared with our instrument built in 2013 from the same company.

In their titration experiment, they performed a series of small injections of $\mathrm{BaCl}_{2}$ into solution of 18-crown-6 $\left(\mathrm{C}^{0}{ }_{\text {lig }}=0.9835 \mathrm{mM}, \mathrm{C}_{\mathrm{Ba} 2+}^{0}=9.994 \mathrm{mM}, 25\right.$ injections $)$. We used very similar conditions and 
performed three replicate runs. In both cases we applied the same software supplied with our modern instrument for thermal peak integration and titration curve analysis. The following results have been obtained (see Tables 2.12 and 2.13 for more information).

- $\quad-31.21 \pm 0.18 \mathrm{~kJ} / \mathrm{mol}$, and $2280 \pm 42 \mathrm{M}^{-1}$ (manufacturer's 2008 data, single titration, no correction for heat of dilution)

- $\quad-30.96 \pm 0.30 \mathrm{~kJ} / \mathrm{mol}$, and $5140 \pm 180 \mathrm{M}^{-1}$ (our data, average of three replicates, no correction for heat of dilution)

- $-28.80 \pm 0.05 \mathrm{~kJ} / \mathrm{mol}$, and $5995 \pm 41 \mathrm{M}^{-1}$ (our data, average of three replicates, with correction for heat of dilution).

Very good agreement in $\Delta \mathrm{H}$ values between our results and manufacturer's titration data (both for uncorrected for heat of dilution data sets) is achieved. However, our value of equilibrium constant is 2.25 times higher than their value. This is an unusual observation because various literature sources typically report much more noticeable differences between magnitudes of $\Delta \mathrm{H}$ rather than those for $\mathrm{K}$. Our $\mathrm{K}$ values both for uncorrected and corrected data sets are in very good agreement with most studies of this complexation reaction (see Table 2.16 to illustrate this comparison).

Regretfully, the 2008 data set from the manufacturer was not supplied to us along with the corresponding heat of dilution data, thus it is not possible to compare our heat of dilution corrected values for $\Delta \mathrm{H}$ and $\mathrm{K}$ with the respective values for the 2008 titration results. It is noteworthy that our corrected value of $\Delta \mathrm{H}$ found in this series of titrations corresponds nicely to the one refined in the first series of titrations and both values are in good agreement with literature data for $\Delta \mathrm{H}_{\mathrm{vH}}$. It also appears that reduction of the reactant concentrations to submillimolar level for the ligand in the ampoule and to less than $10 \mathrm{mM}$ for the metal in the syringe, and performing a greater number of injections with lower injected volumes helps reduce uncertainty in the refined values of $\Delta \mathrm{H}$ from $0.95 \mathrm{~kJ} / \mathrm{mol}$ down to $0.05 \mathrm{~kJ} / \mathrm{mol}$ for the heat of dilution corrected thermograms.

Finally, it would be appropriate to conclude this section by quoting a couple of passages from Mizoue and Tellingshuisen's paper regarding validity of the heat of dilution subtraction procedure for this particular reaction of $\mathrm{Ba}^{2+}$ complexation by 18 -crown- 6 .

\section{Excerpt 1:}

Reflection on the standard procedure of subtracting a blank from the sample thermogram shows that there is an 'apple-vs.-oranges' component to this operation. For illustration purposes, suppose that reaction (2)

$$
B a_{(a q)}^{2+}+\text { ether }_{(a q)}=B a^{2+} \cdot \text { ether }_{(a q)}
$$

has a very large $K[M]_{0}$, say $>1000$. For early injections of titrant, the reaction goes nearly to completion, so each successive injection is into a system that has almost no $\mathrm{Ba}^{2+}$. At the same time the concentration of anion $\left(\mathrm{Cl}^{-}\right.$or $\left.\mathrm{NO}_{3}^{-}\right)$and complex are building up. Past the equivalence point, $\mathrm{Ba}^{2+}$ begins to grow, while the concentration of the complex varies little. But in the blank, the cell concentration of the titrant is continually increasing. Thus, simply subtracting the blank does not properly account for the more complex processes that are occurring. In particular, it does not convert the data to the form implied by the thermodynamics: reactants at infinite dilution to 
products at infinite dilution. For reference, it is useful to note that for $\mathrm{BaCl}_{2}$, the blank correction can be $\sim 10 \%$ of the largest sample peak, and it can account for most of the raw heat in late injections.

\section{Excerpt 2:}

Statistically significant difference is observed not only in the calorimetric/vH comparison but also in the directly estimated $\Delta H_{\text {cal }}$ values for two different sources of $\mathrm{Ba}^{2+}, \mathrm{BaCl}_{2}$ and $\mathrm{Ba}\left(\mathrm{NO}_{3}\right)_{2}$. The discrepancies are tentatively attributed to flaws in the standard procedure, in which a blank obtained for pure titrant $\left(\mathrm{BaCl}_{2}\right)$ is subtracted from the thermogram obtained for the sample. Correction for these effects will require specific consideration of heats of dilution of not only the titrant $\left(\mathrm{BaCl}_{2}\right.$ or $\left.\mathrm{Ba}\left(\mathrm{NO}_{3}\right)_{2}\right)$ but also for the product $\mathrm{Ba}^{2+}$.ether $\mathrm{X}$ where $\mathrm{X}=\mathrm{Cl}^{-}$or $\mathrm{NO}_{3}^{-}$) Moreover, these processes must be addressed within the fit model, as their roles change during the course of the titration.

\subsubsection{Conclusions}

The well-studied 1:1 complexation reaction between $\mathrm{Ba}^{2+}$ and 18-crown-6 ether was performed to test performance and accuracy of the recently acquired TAM-III isothermal titration calorimeter. Two thermodynamic parameters of this reaction were refined from the titration data: the enthalpy of the complex formation $(\Delta \mathrm{H}, \mathrm{kJ} / \mathrm{mol})$ and the equilibrium constant $\left(\mathrm{K}, \mathrm{M}^{-1}\right)$.

During the first round of titrations, a stock solution of the ligand prepared in our analytical laboratory 3.5 years ago was used with concentration of $5.04 \mathrm{mM}$. Application of this solution as titrate (ampoule) with incremental injection of $\mathrm{BaCl}_{2}$ as titrant (syringe) resulted in systematically low values of both $-\Delta \mathrm{H}$ and $\mathrm{K}$. We suggest that in the process of such a prolonged storage, the ligand partially reacted with components of the glass bottle container and leached small amounts of $\mathrm{M}^{+}$(sodium, potassium) and $\mathrm{M}^{2+}$ ions (calcium, magnesium) from the glass. This negative bias in both thermodynamic parameters of the test reaction indicated insufficient purity of the ether and subsequent testing was done with purified ligand following recrystallization from acetonitrile (Gokel et al. 1974) with subsequent solvent removal at elevated temperatures $\left(45-60^{\circ} \mathrm{C}\right)$ under a flow of dry argon.

Two series of titrations with purified ligand were performed with four replicates within each series. The results of these experiments are presented in Tables 2.12, 2.13, 2.14, and 2.15. These data can be further summarized as shown in Table 2.16 where data from this project are presented in the top section of the table as an average of all five modes of data processing. 
Table 2.16. Summary of All Titrations Performed in the Course of this Project (only the purified ligand data are shown) and Their Comparison with the Instrument Manufacturer and Literature Data

\begin{tabular}{|c|c|c|c|}
\hline $\begin{array}{c}\text { Experiment Description } \\
\text { or Literature Data } \\
\text { Details }\end{array}$ & $\begin{array}{c}\text { Heat of Dilution of Titrant } \\
\left(\mathrm{BaCl}_{2}\right) \text { Applied to Correct } \\
\text { the Complexation } \\
\text { Thermogram? } \\
\text { Yes/No/Not Clear }\end{array}$ & $-\Delta \mathrm{H}, \mathrm{kJ} / \mathrm{mol}\left(\right.$ at $\left.25^{\circ} \mathrm{C}\right)$ & $\mathrm{K}, 1 / \mathrm{M}\left(\right.$ at $\left.25^{\circ} \mathrm{C}\right)$ \\
\hline \multirow{2}{*}{$\begin{array}{c}1^{\text {st }} \text { series }\left(C_{\text {lig }}^{0}=\right. \\
1.97 \mathrm{mM}, C_{\mathrm{Ba} 2+}^{0}= \\
\text { 16.785 mM }), 11 \text { large } \\
\text { injections }\end{array}$} & No & $30.97 \pm 1.15$ & $5140 \pm 830$ \\
\hline & Yes & $28.91 \pm 0.95$ & $6100 \pm 890$ \\
\hline $2^{\text {nd }} \operatorname{series}\left(C_{\text {lig }}^{0}=\right.$ & No & $30.96 \pm 0.30$ & $5140 \pm 180$ \\
\hline $\begin{array}{c}0.9835 \mathrm{mM}, \mathrm{C}_{\mathrm{Ba2}+}^{0}= \\
8.516 \mathrm{mM}), 25 \text { small } \\
\text { injections }\end{array}$ & Yes & $28.80 \pm 0.05$ & $5995 \pm 41$ \\
\hline $\begin{array}{c}\text { TAMIII manufacturer } \\
\text { data (single titration } \\
\text { with } C^{0}{ }_{l i g}=0.9835 \mathrm{mM}, \\
\mathrm{C}^{0}{ }_{\mathrm{Ba} 2+}=9.994 \mathrm{mM}, 25 \\
\text { small injections) }\end{array}$ & No & $31.21 \pm 0.18$ & $2280 \pm 42$ \\
\hline $\begin{array}{l}\text { Literature data } \\
\text { (Buschmann and } \\
\text { Schollmeyer 1999) }\end{array}$ & Not Clear & $31.5 \pm 1.2$ & $\begin{array}{l}\log K=3.50 \pm 0.08 \\
(K \text { varies from } 2630 \\
\text { to } 4790)\end{array}$ \\
\hline $\begin{array}{l}\text { Literature data (Mizoue } \\
\text { et al. 2004, direct } \\
\text { calorimetric data } \\
\text { (average of } 7 \text { titrations } \\
\text { with } \mathrm{BaCl}_{2} \text { as titrant) }\end{array}$ & Yes & $32.04 \pm 0.28$ & $5560 \pm 100$ \\
\hline $\begin{array}{l}\text { Literature data (Mizoue } \\
\text { and Tellinghuisen } 2004 \\
\text { (van't Hoff data for } \Delta H \\
\text { derived from their Fig. } \\
6 \text { ) }\end{array}$ & Yes & $\begin{array}{c}(28.3+30.0) / 2=29.15 \pm \\
0.85\end{array}$ & 5560 \\
\hline $\begin{array}{l}\text { Literature data (Liu and } \\
\text { Sturtevant 1995) }\end{array}$ & Yes & $\begin{array}{c}31.42 \text { (by } \\
\text { microcalorimetry) } \\
28.07 \text { (by van't Hoff eqn.) }\end{array}$ & $5140 \pm 40$ \\
\hline $\begin{array}{c}\text { Literature data } \\
\text { (Solov'ev et al. 1998) }\end{array}$ & Not Clear & $29.7 \pm 0.5$ & $\begin{array}{l}\log K=3.80 \pm 0.03 \\
\text { (K varies from } 5900 \\
\text { to } 6760 \text { ) }\end{array}$ \\
\hline
\end{tabular}

From the obtained results, it can be concluded that the instrument is fully operational and, once commissioned for radiological work, can be used to study the thermodynamics of $\mathrm{Tc}(\mathrm{CO})_{3}{ }^{+}$reactions with organic ligands that are likely to be responsible for stabilization of this less common monovalent oxidation state of Tc in non-pertechnetate-containing Hanford tanks. 


\subsection{Tc Sensor Task Summary}

\subsubsection{Introduction}

The form of the non-pertechnetate Tc complex has been documented to be the $\left[\operatorname{Tc}(\mathrm{CO})_{3}\left(\mathrm{H}_{2} \mathrm{O}\right)_{3}\right]^{+}$or ligand substituted complex $\left[\mathrm{Tc}(\mathrm{CO})_{3}(\mathrm{X})\left(\mathrm{H}_{2} \mathrm{O}\right)\right]^{+}$(where $\mathrm{X}$ is a multidentate ligand, such as glycolate, citrate, or oxalate) (Lukens et al. 2004). While the $\left[\mathrm{Tc}(\mathrm{CO})_{3}\left(\mathrm{H}_{2} \mathrm{O}\right)_{3}\right]^{+}$and related complexes are not readily detected optically, we proposed in FY 2013 to convert $\left[\mathrm{Tc}(\mathrm{CO})_{3}\left(\mathrm{H}_{2} \mathrm{O}\right)_{3}\right]^{+}$into a fluorescent complex that would be detectable at the concentrations found in tank waste.

The direct reaction of $\left[\mathrm{Tc}(\mathrm{CO})_{3}\left(\mathrm{H}_{2} \mathrm{O}\right)_{3}\right]^{+}$or $\left[\mathrm{Tc}(\mathrm{CO})_{3}(\mathrm{X})\left(\mathrm{H}_{2} \mathrm{O}\right)\right]^{+}$with bidentate and tridentate ligands has been established under conditions (neutral and basic $\mathrm{pH}$, at room temperature, saline) suitable for radiotherapeutic applications (Alberto 1998a,b,c). By changing the nature of the entering ligand groups to bipyridine (bpy) or functionalized bpy ligands, we propose to convert the $\left[\mathrm{Tc}(\mathrm{CO})_{3}\left(\mathrm{H}_{2} \mathrm{O}\right)_{3}\right]^{+}$complex into optically emissive complexes with the formula $\left[\mathrm{Tc}(\mathrm{CO})_{3}(\mathrm{~L} \sim \mathrm{L})_{2}\right]^{+}$according to the scheme shown below. The list of entering bi-dentate ligands ( $\sim \mathrm{L})$ includes: dtbbpy, dmbpy, dmebpy, bpy, and dcbbpy.

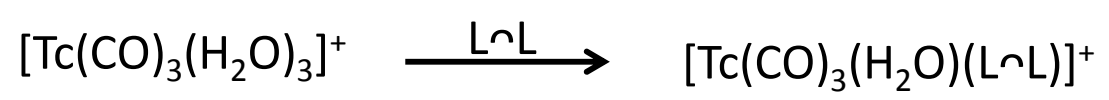

Analogs of the Tc(I) complexes we propose for this study, a range of Re(I) complexes, previously have been shown to be emissive (Richter et al. 1996). We are certain, based on our past work demonstrating the first documented examples of emissive technetium complexes (Del Negro et al. 2005; Del Negro et al. 2006), that these related new Tc(I) complexes will show fluorescent properties as well.

In collaboration with the University of Cincinnati, we have also developed and demonstrated a selective optical sensor for the luminescent Tc(II) complex $\left[\mathrm{Tc}(\mathrm{dmpe})_{3}\right]^{2+}$, which is composed of a selective polymer film that preconcentrates the Tc complex within the spectroelectrochemical compartment of the sensor. After the Tc complex is absorbed into the polymer film, the cell is activated electrochemically and the $\left[\mathrm{Tc}(\mathrm{dmpe})_{3}\right]^{2+}$ complex is modulated between the $\mathrm{Tc}(\mathrm{I})$ (non-emissive) and the $\mathrm{Tc}(\mathrm{II})$ (emissive) redox states. The recorded luminescent emission was demonstrated to be proportional to Tc concentration, linear over 5-6 orders of magnitude in concentration, and with a detection limit at the nanomolar level (Chatterjee et al. 2011a, b).

This task seeks to convert the non-emissive $\left[\mathrm{Tc}(\mathrm{CO})_{3}\left(\mathrm{H}_{2} \mathrm{O}\right)_{3}\right]^{+}$and $\left[\mathrm{Tc}(\mathrm{CO})_{3}\left(\mathrm{H}_{2} \mathrm{O}\right)_{\mathrm{m}} \mathrm{X}\right]^{+}$complexes into the emissive $\left[\mathrm{Tc}(\mathrm{CO})_{3}(\mathrm{~L} \sim \mathrm{L})_{2}\right]^{+}$complex, followed by the fluorescence mode detection of these new species within a polymer-film-based sensor. This report details the experimental work performed during FY 2013 to accomplish these goals.

\subsubsection{Experimental}

The methodology for the detection of Tc complex centers around the formation of an emissive Tc(I) complex with the general formula $\mathrm{Tc}(\mathrm{CO})_{3}(\mathrm{~L}-\mathrm{L}) \mathrm{X}$. $\operatorname{Re}(\mathrm{I})$ analogues to the Tc system will also be used in testing the methodology of the sensor concept. The Tc-carbonyl and Re-carbonyl complexes targeted are also electroactive, which lends their detection by using the spectroelectrochemical technique. This 
section of the report describes the general system development and testing performed to provide a basis for later sensor measurement.

\subsubsection{Preparation of Complexes}

\subsection{Re Complexes}

$\operatorname{Re}(\mathrm{CO})_{3}($ bpy $) \mathrm{Cl}$ and $\operatorname{Re}(\mathrm{CO})_{3}($ tbbpy $) \mathrm{Cl}$, (bpy= 2,2'-bipyridine, dtbbpy = 4, 4'-di-tert-butyl-2, 2'-bipyridine, dmbpy = 4, 4'-dimethyl-2, 2'-bipyridine, dmeobpy = 4, 4'-dimethoxy-2, 2'-bipyridine, dcbpy $=4$, 4'-dicarbomethoxy-2, 2'-bipyridine), were prepared using the method reported by Smieja and Kubiak (2010).

\subsection{Tc Complexes}

The starting material, $\left(\mathrm{Et}_{4} \mathrm{~N}\right)_{2}\left[\mathrm{Tc}(\mathrm{CO})_{3} \mathrm{Cl}_{3}\right]$, was synthesized following the procedure as described previously in this report (Kurz et al. 2006). This complex was the starting material used for preparation of $\left[\mathrm{Tc}(\mathrm{CO})_{3}(\text { bpy })\left(\mathrm{H}_{2} \mathrm{O}\right)\right]^{+}$and $\left[\mathrm{Tc}(\mathrm{CO})_{3}(\text { phen })\left(\mathrm{H}_{2} \mathrm{O}\right)\right]^{+}$complexes (phen = 1,10-phenanthroline).

$\left[\mathbf{T c}(\mathbf{C O})_{3}(\mathbf{b p y})\left(\mathrm{H}_{2} \mathbf{O}\right)\right]^{+}$. Approximately $10 \mathrm{mg}$ of $\left(\mathrm{Et}_{4} \mathrm{~N}\right)_{2}\left[\mathrm{Tc}(\mathrm{CO})_{3} \mathrm{Cl}_{3}\right]$ was dissolved in $2 \mathrm{ml} \mathrm{H}_{2} \mathrm{O}$. This solution was stirred for 20 minutes before adding $1.5 \mathrm{ml}$ of a $2: 1 \mathrm{H}_{2} \mathrm{O}: \mathrm{EtOH}$ solution with $5.38 \mathrm{mg}$ (34 mM) of dissolved bpy. After about 2 hours, an additional $1 \mathrm{ml}$ of a 2:1 $\mathrm{H}_{2} \mathrm{O}:$ EtOH solution with $2.93 \mathrm{mg}(19 \mathrm{mM})$ of dissolved bpy was added. This resulted in an approximately 3:1 molar ratio between the ligand and metal complex. After several hours the solution had a yellow color. The solution was stirred overnight. Samples of the reaction solution containing $\left[\mathrm{Tc}(\mathrm{CO})_{3}(\text { bpy })\left(\mathrm{H}_{2} \mathrm{O}\right)\right]^{+}$were taken for spectroscopic measurements and are discussed below.

$\left[\mathbf{T c}(\mathbf{C O})_{3}(\text { phen })\left(\mathrm{H}_{2} \mathbf{O}\right)\right]^{+}$. Approximately $10 \mathrm{mg}$ of synthesized $\left(\mathrm{Et}_{4} \mathrm{~N}\right)_{2}\left[\mathrm{Tc}(\mathrm{CO})_{3} \mathrm{Cl}_{3}\right]$ was dissolved in $2 \mathrm{ml} \mathrm{H}_{2} \mathrm{O}$. This solution was stirred for 20 minutes before adding $1 \mathrm{ml}$ of a 2:1 $\mathrm{H}_{2} \mathrm{O}$ :EtOH solution with $12.07 \mathrm{mg}(67 \mathrm{mM})$ of dissolved phen. This addition resulted in a 3:1 ratio between the ligand and metal complex. The solution was stirred overnight and appeared to be a yellowish suspension the following morning. Samples of the reaction solution containing $\left[\mathrm{Tc}(\mathrm{CO})_{3}(\mathrm{phen}) \mathrm{H}_{2} \mathrm{O}\right]^{+}$were taken for spectroscopic measurements and are discussed below.

\subsubsection{Electrochemistry, Spectroscopy, and Spectroelectrochemistry}

Electrochemistry. Electrochemical measurements were carried out using a PAR 273A Potentiostat (EG\&G) controlled with CorrWare software v. 3.3b (Scribner Assoc.) or an Epsilon Potentiostat (Bioanalytical Systems) with a standard three-electrode cell stand from Bioanalytical Systems. The electrochemical system comprised of a 100 mesh Pt working electrode (Sigma - Aldrich, 99.9\%, 2980931), Pt wire auxiliary electrode, and $\mathrm{Ag} / \mathrm{AgCl}$ reference electrode (BASi). All solutions were dissolved in either water with $0.1 \mathrm{M} \mathrm{KNO}_{3}$ supporting electrolyte or acetonitrile with $0.1 \mathrm{M}$ TBAPF 6 (tetra-n-butyl ammonium hexafluorophosphate) supporting electrolyte.

Cyclic voltammetry. Cyclic voltammetry is used to determine the redox potentials of electrochemically active complexes. Electrochemistry (controlled potential electrolysis) is used to tune the target complex to the desired oxidation state for optimum optical detection. A combination of electrochemical and optical spectroscopic measurement (spectroelectrochemistry) is used to observe the 
spectroscopic response to the electrochemically generated species in solution. This spectroelectrochemical technique was used to measure the redox active Tc complexes within this study.

Cryogenic laser fluorescence spectroscopy. The instrumentation and experimental procedures for fluorescence spectroscopic measurements at liquid helium temperature were described previously (Wang et al. 2005a; Wang et al. 2005b). The quartz sample cuvettes were attached to the cold finger of a CRYO Industries RC152 cryostat with liquid helium vaporizing beneath the sample to reach a sample temperature of $8 \pm 2^{0} \mathrm{~K}$. The sample was excited with a Spectra-Physics Nd:YAG laser pumped Lasertechnik-GWU MOPO laser at $415 \mathrm{~nm}$ and the emitted light was collected at $85^{\circ}$ to the excitation beam and detected with a thermoelectrically cooled Princeton Instruments PIMAX intensified CCD camera after spectral dispersion through an Acton SpectroPro 300i double monochromator spectrograph.

Solution absorption and emission spectroscopy. UV-visible absorption spectra were recorded with a deuterium light source (Mikropack, model\# DH 2000) and an Ocean Optics USB2000 detector $(188-880 \mathrm{~nm})$ using Spectra Suite Software for spectral data acquisitions. Emission spectra were recorded using a $532 \mathrm{~nm}$ laser excitation source (Melles Griot, $20 \mathrm{~mW} \mathrm{CW}$ ), coupled to an InSpectrum 150 spectrometer-CCD, and using SpectraSense data acquisition software. A $532 \mathrm{~nm}$ holographic notch filter (Kaiser) was used to reduce laser light backscattered into the InSpectrum 150 spectrometer. Signal integration times were typically $500 \mathrm{~ms}$ using a 2-mm slit width for a $600 \mathrm{gr} / \mathrm{mm}$ grating blazed at $500 \mathrm{~nm}$. Step index silica-on-silica optical fibers were purchased from Romack, Inc. The Ocean Optics system consisted of a USB-200FL spectrometer and Ocean Optics 00IBase32 Spectroscopy Software. For absorption mode spectroelectrochemical measurements under absorption mode, a BASi thin layer $(1 \mathrm{mM})$ absorbance cell was used as shown in Figure 2.19. For emission measurements, a 180 backscattering fiber-optic probe was used for collection of emission measurements using a microdrop spectroelctrochemical cell shown in Figure 2.20.

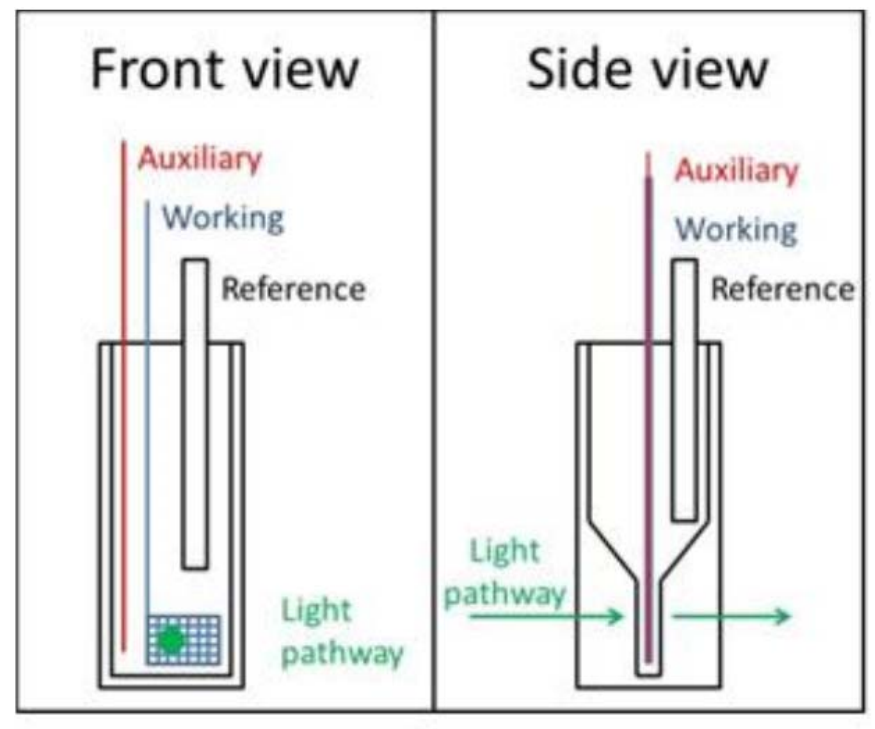

1a.

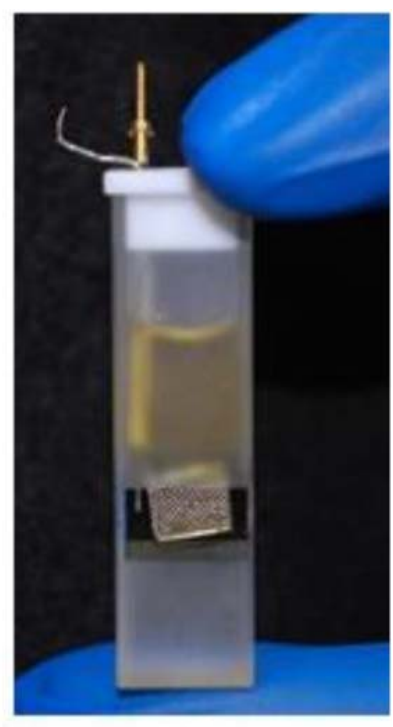

$1 b$.

Figure 2.19. Absorbance-based Spectroelectrochemical Cell. (1a) Schematic of BASi cell showing front view and side view with optical path. (1b) Photograph of BASi cell with platinum mesh electrode inserted. 

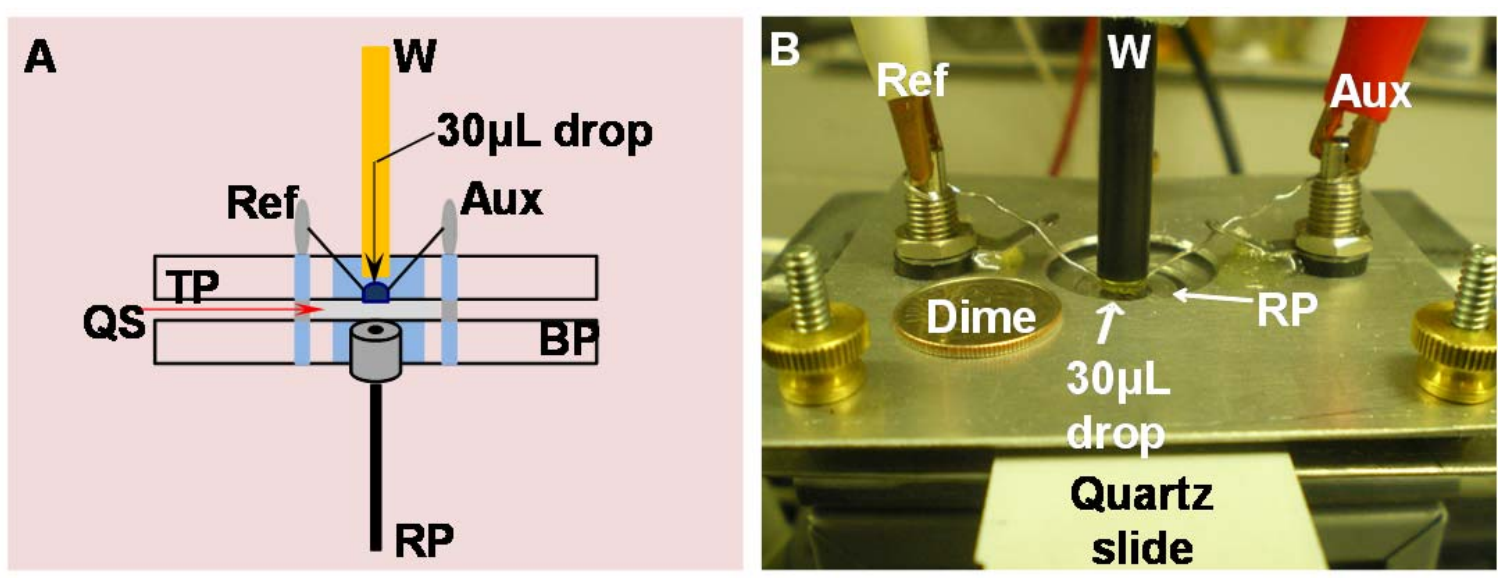

Figure 2.20. (A) Schematic Representation of Spectroelectrochemical Setup Using an Aqueous Micro-Drop; (B) Photograph of the Cell (W = working electrode, Ref $=$ reference electrode, Aux $=$ auxiliary electrode, $\mathrm{TP}=$ top plate, $\mathrm{QS}=$ quartz slide, $\mathrm{BP}=$ bottom plate, $\mathrm{RP}=$ reflectance probe). A US dime is shown for size comparison.

\subsubsection{Spectroelectrochemical Sensor Measurements}

This section demonstrates the spectroelectrochemical sensor methodology using model compounds and analogues to the Tc-carbonyl system.

The $\mathrm{Ru}(\mathrm{bpy})_{3}{ }^{2+}$ complex is a model complex for electrochemical and optical emission measurements, and is used here to optimize the experimental system. Figure 2.21 shows the cyclic voltammogram (CV) for the $\left[\mathrm{Ru}(\mathrm{bpy})_{3}\right]^{2+/ 3+}$ couple in aqueous solution showing the expected reversible electrochemical redox behavior for the $\mathrm{Ru}(\mathrm{II} / \mathrm{III})$ complex. From this $\mathrm{CV}$, the $\mathrm{E}^{\mathrm{o}^{\prime}}$ was calculated to be $1.065 \mathrm{~V}$.

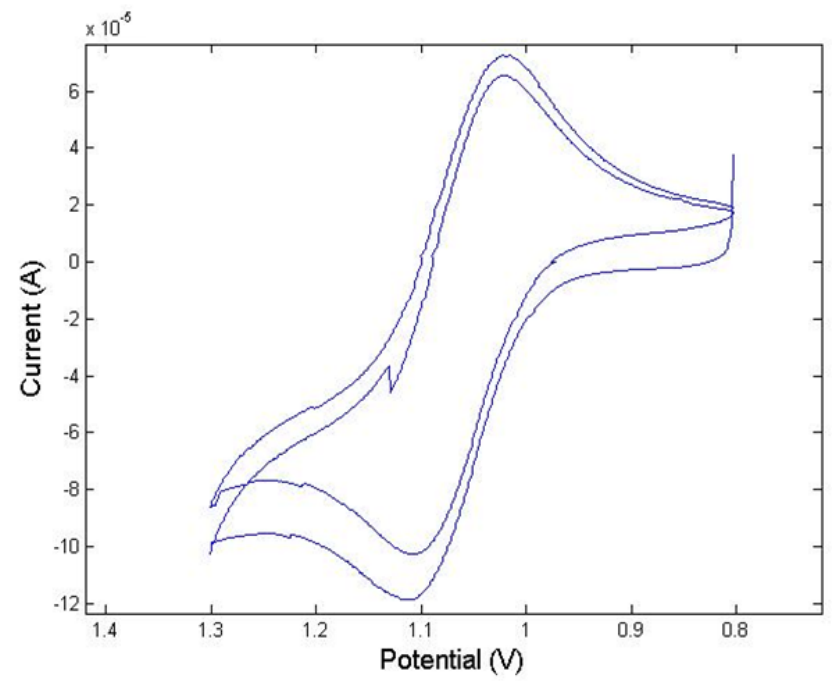

Figure 2.21. $\mathrm{CV}$ of $5 \mathrm{mM} \mathrm{Ru}(\mathrm{bpy})_{3}{ }^{2+}$ in $0.1 \mathrm{M} \mathrm{KNO}_{3}$ Using a Pt Mesh Working Electrode, Pt Auxilliary Electrode, and $\mathrm{Ag} / \mathrm{AgCl}$ Reference. The sample was scanned from 0.8 to $1.3 \mathrm{~V}$ at a scan rate of $2 \mathrm{mV} / \mathrm{s}$; $\mathrm{E}^{\mathrm{o}^{\prime}}$ was calculated to be $1.065 \mathrm{~V}$. 
Using the electrochemical widow established from the CV above, the spectroelectrochemical measurement of the $\left[\mathrm{Ru}(\mathrm{bpy})_{3}\right]^{2+}$ complex was measured and is shown in Figure 2.22. The potential was stepped from $1 \mathrm{~V}$ to $1.1 \mathrm{~V}$ in steps of $0.02 \mathrm{~V}$ where the applied potential was held for 10 minutes. The experiment was performed using a BASi thin cell with Pt mesh working elctrode, Pt auxilliary, and $\mathrm{Ag} / \mathrm{AgCl}$ reference.
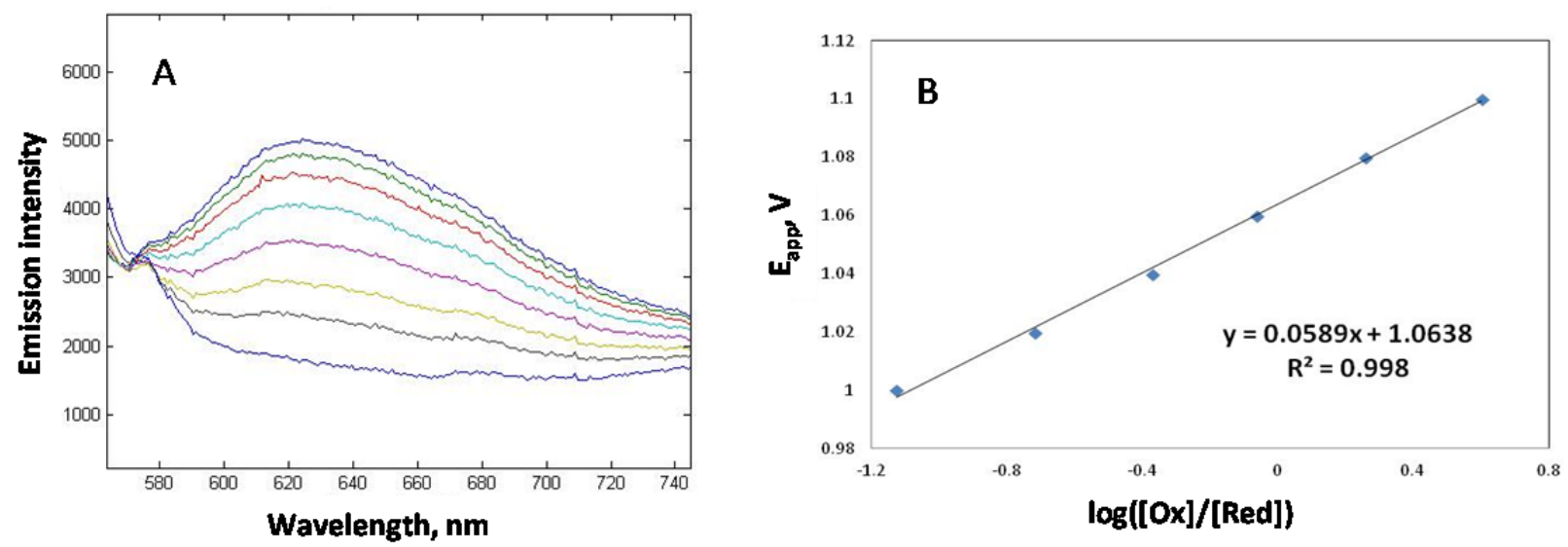

Figure 2.22. (A) Modulation of Luminescence Intensity of an Aqueous Solution $x 10^{-3} \mathrm{M}\left[\mathrm{Ru}(\mathrm{bpy})_{3}\right]^{2+}$ in $0.1 \mathrm{M} \mathrm{KNO}_{3}$ with Time on the Application of Voltage $\left(\lambda_{\mathrm{ex}}=532 \mathrm{~nm}\right)$; (B) Nernst Plot of $\log [\mathrm{Ox}] /[\mathrm{Red}]$ vs. $\mathrm{E}_{\text {app }}$ vs. $\mathrm{Ag} / \mathrm{AgCl}$ at $620 \mathrm{~nm}$

Emission spectra, redox potentials and electron transfer stoichiometries were also determined by thinlayer spectroelectrochemistry (Kissinger and Heineman 1996; DeAngelis and Heineman 1976). In our experimental technique, $\mathrm{Ru}^{3+}$ is incrementally converted to $\mathrm{Ru}^{2+}$ by a series of applied potentials so that the ratio of $\mathrm{Ru}^{3+}$ to $\mathrm{Ru}^{2+}$ in the thin-layer cell is varied according to the Nernst Equation:

$$
E_{\text {app }}=E^{0^{\prime}}+2.303\left(\frac{R T}{n F}\right) \log \frac{[\text { Ox }]}{[\text { Red }]}
$$

where $\mathrm{E}^{\mathrm{O}}$ is the formal reduction potential, $\mathrm{R}$ is the gas constant, $\mathrm{T}$ is the temperature in Kelvin, $\mathrm{F}$ is Faraday's constant, $\mathrm{n}$ is the electron transfer stoichiometry, and [Ox] and [Red] are the respective concentrations of the oxidized and reduced species. The ratio $[\mathrm{Ox}] /[\mathrm{Red}]$ at each applied potential $E_{\text {app }}$ was estimated from $\left(I-I_{\mathrm{red}}\right) /\left(I_{\mathrm{ox}}-I\right)$, where $I$ is the emission intensity at a given wavelength, according to literature methods described by Heineman and coworkers (Kissinger and Heineman 1996; DeAngelis and Heineman 1976). Figure 2.22A shows the emission spectra for $5 \mathrm{mM}\left[\mathrm{Ru}(\mathrm{bpy})_{3}\right]^{2+}$ in aqueous $0.1 \mathrm{M}$ $\mathrm{KNO}_{3}$ when various potentials are applied. The spectrum with the least emission intensity at $620 \mathrm{~nm}$ is at $\mathrm{E}_{\text {app }}=1.1 \mathrm{~V}$ when $\mathrm{Ru}$ is fully oxidized to $\mathrm{Ru}^{3+}$, while the spectrum with the most emission intensity at $620 \mathrm{~nm}$ is at $E_{\text {app }}=1.0 \mathrm{~V}$ is the fully reduced form, $\mathrm{Ru}^{2+}$.

Based on the Nernst analysis, the slope of the fit of the line of $E_{\text {app }} \mathrm{vs} \log ([\mathrm{Ox}] /[\mathrm{Red}])$, yields the $\mathrm{E}^{\mathrm{o}^{\prime}}$ value of $1.0634 \mathrm{~V}$ as the $\mathrm{y}$-intercept value, which is close to the $\mathrm{CV}$ value measured above $(1.065 \mathrm{~V})$. The slope yields the Nersnt constant of 0.0589 , which is close (within $0.3 \%$ ) of theoretical value $(0.0591$ ) for the expected one electron transfer for the $\mathrm{Ru}(\mathrm{II} / \mathrm{III})$ couple. 
The modulation of $5 \mathrm{mM}\left[\mathrm{Ru}(\mathrm{bpy})_{3}\right]^{2+/ 3+}$ in $0.1 \mathrm{M} \mathrm{KNO}_{3}$ was performed using a step potential reduction/oxidation wave form in the spectroelectrochemical cell, as shown in Figure 2.23. The potential was modulated as a step function between $1.3 \mathrm{~V}$ and $0.8 \mathrm{~V}$ where the potential was held for 5 minutes at each potential. A total of three redox cycles were performed. When the potential was held at $0.8 \mathrm{~V}$, the $\mathrm{Ru}$ complex was reduced to the $\mathrm{Ru}(\mathrm{II})$ form $\left(\left[\mathrm{Ru}(\mathrm{bpy})_{3}\right]^{2+}\right.$ ), which is emissive; when the potential was held at $1.3 \mathrm{~V}$, the $\mathrm{Ru}$ complex was oxidized to the $\mathrm{Ru}(\mathrm{III})$ form $\left(\left[\mathrm{Ru}(\mathrm{bpy})_{3}\right]^{3+}\right)$, which is non-emissive. The experiment was completed using the microdrop apparatus with a Pt wire working electrode, $\mathrm{Pt}$ auxiliary, and an $\mathrm{Ag} / \mathrm{AgCl}$ micro reference.
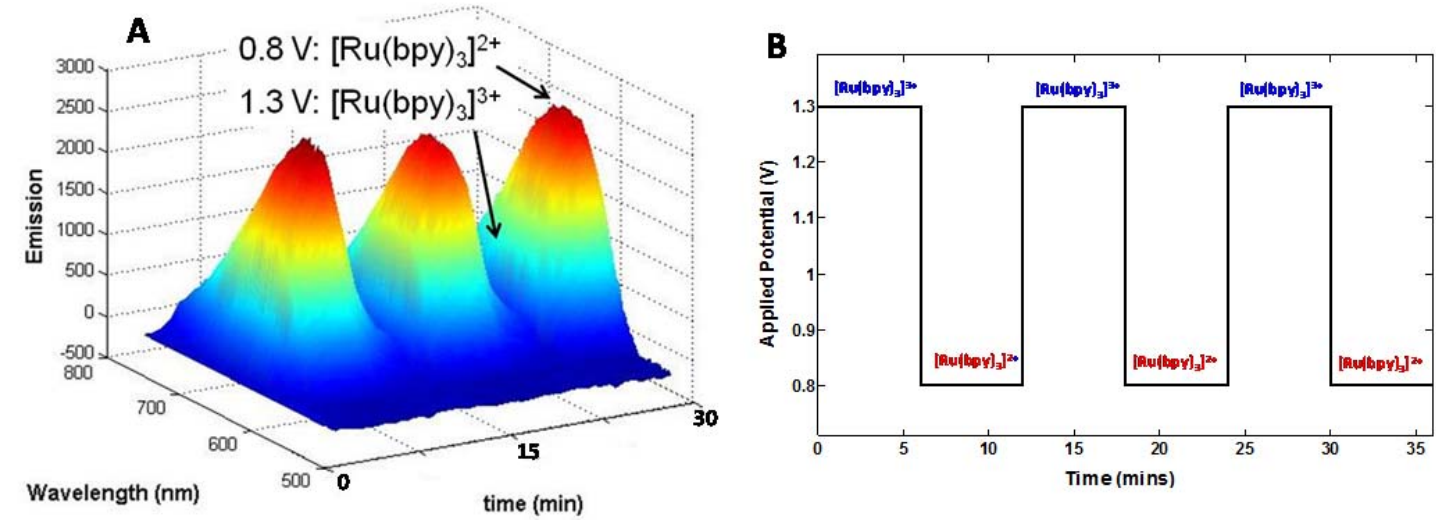

Figure 2.23. (A) Modulation of $5 \mathrm{mM}\left[\mathrm{Ru}(\mathrm{bpy})_{3}\right]^{2+/ 3+}$ in $0.1 \mathrm{M} \mathrm{KNO}_{3}$; (B) Potential was Modulated Between 1.3 V and 0.8 V Where the Potential was Held for Five Minutes. Experiment was completed using the microdrop apparatus with a Pt wire working electrode, Pt auxiliary, and an $\mathrm{Ag} / \mathrm{AgCl}$ micro reference.

\subsubsection{Re Analogues of Tc System}

In order to optimize the detection system, Re analogues of the Tc target complexes were tested by electrochemical and spectroscopic analysis.

Absorption and fluorescence emission measurements were performed to demonstrate absorption maximum and emission characteristics of the Re complexes. Figure 2.24 shows the absorption and emission spectra for the $\mathrm{Re}(\mathrm{dbbpy})(\mathrm{CO})_{3} \mathrm{Cl}$ complex. 

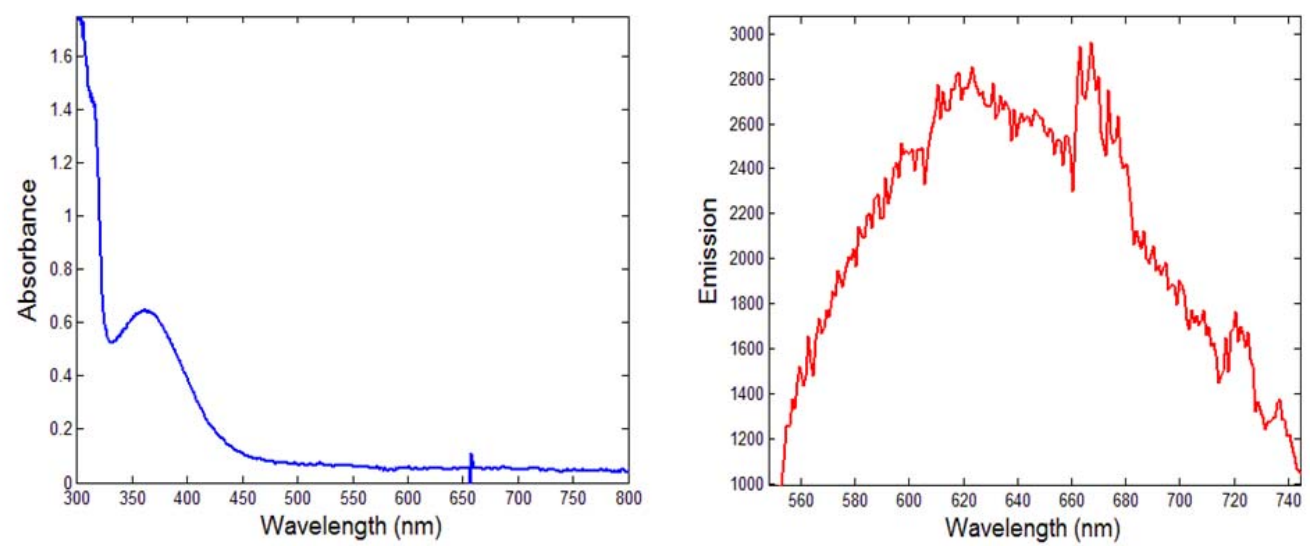

Figure 2.24. Emission (left) and Absorption (right) Spectra of $\mathrm{Re}(\mathrm{dbbpy})(\mathrm{CO})_{3} \mathrm{Cl}$. For emission a $10 \mathrm{mM} \mathrm{Re}(\mathrm{dbbpy})(\mathrm{CO})_{3} \mathrm{Cl}$ and $0.1 \mathrm{M}$ Tetra-n-butylammonium chloride (TBACl) solution in DMF was excited using a $405 \mathrm{~nm}$ laser.

CVs of two Re-carbonyl complexes that are analoges to the Tc-carbonyl target system are shown in Figure 2.25. The $\mathrm{CV}$ of the $\mathrm{Re}(\mathrm{bpy})(\mathrm{CO})_{3} \mathrm{Cl}$ complex is shown in Figure $2.25 \mathrm{~A}$ and $\mathrm{Re}(\mathrm{dbbpy})(\mathrm{CO})_{3} \mathrm{Cl}$ is shown in Figure 2.25B. For both complexes, $10 \mathrm{mM}$ of complex was used, with a supporting electrolyte of $0.1-\mathrm{M} \mathrm{TBAPF}$ in acetonitrile. Sample CVs were scanned from -0.5 to $-2.6 \mathrm{~V}$ at a scan rate of $100 \mathrm{mV} / \mathrm{s}$. For both complexes, two electrochemical reduction waves are observed when the potential is scanned in the negative direction, the first corresponding to the $\operatorname{Re}(\mathrm{I} / 0)$ couple, the second more negative reduction has been ascribed to a ligand based reduction (Richter et al. 1996).
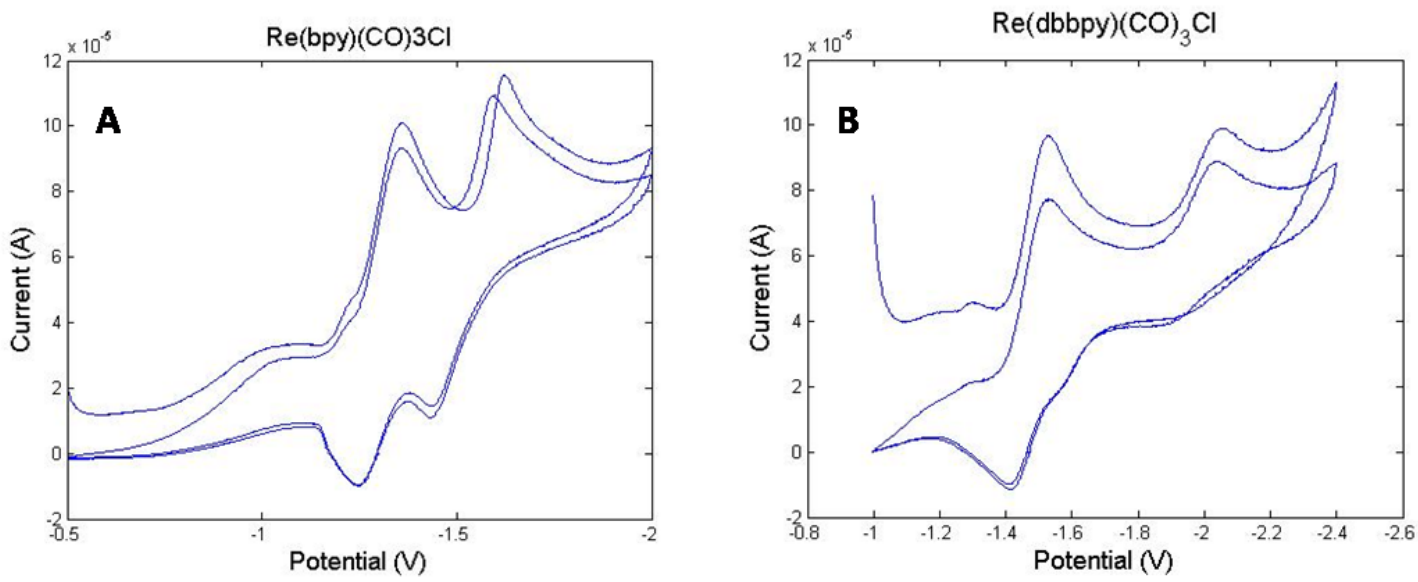

Figure 2.25. $\mathrm{CV}$ of $10 \mathrm{mM} \mathrm{Re}($ dbbpy $)(\mathrm{CO})_{3} \mathrm{Cl}(\mathrm{B})$ and $10 \mathrm{mM} \operatorname{Re}($ bpy $)(\mathrm{CO})_{3} \mathrm{Cl}(\mathrm{A})$, Both with $0.1 \mathrm{M}$ $\mathrm{TBAPF}_{6}$ in Acetonitrile. Sample was scanned from -0.5 to $-2.6 \mathrm{~V}$ at a scan rate of $100 \mathrm{mV} / \mathrm{s}$.

Figure 2.26 shows $\mathrm{CV}$ performed under variable scan rates for the $\mathrm{Re}(\mathrm{dbbpy})(\mathrm{CO})_{3} \mathrm{Cl}$ complex (center figure), where the applied electrochemical potential was limited beween 0.5 and $-2 \mathrm{~V}$. This $\mathrm{CV}$ demonstrates the reversible electrochemical behavior of the $\operatorname{Re}(\mathrm{I} / 0)$ couple for the $\operatorname{Re}(\mathrm{dbbpy})(\mathrm{CO}){ }_{3} \mathrm{Cl}$ complex under these conditions. 
The absorbance measurement of the fully oxidized $\operatorname{Re}(\mathrm{I})$ complex is shown in the left figure, while the absorbance measurement of the fully reduced $\operatorname{Re}(0)$ complex is shown in the right figure.

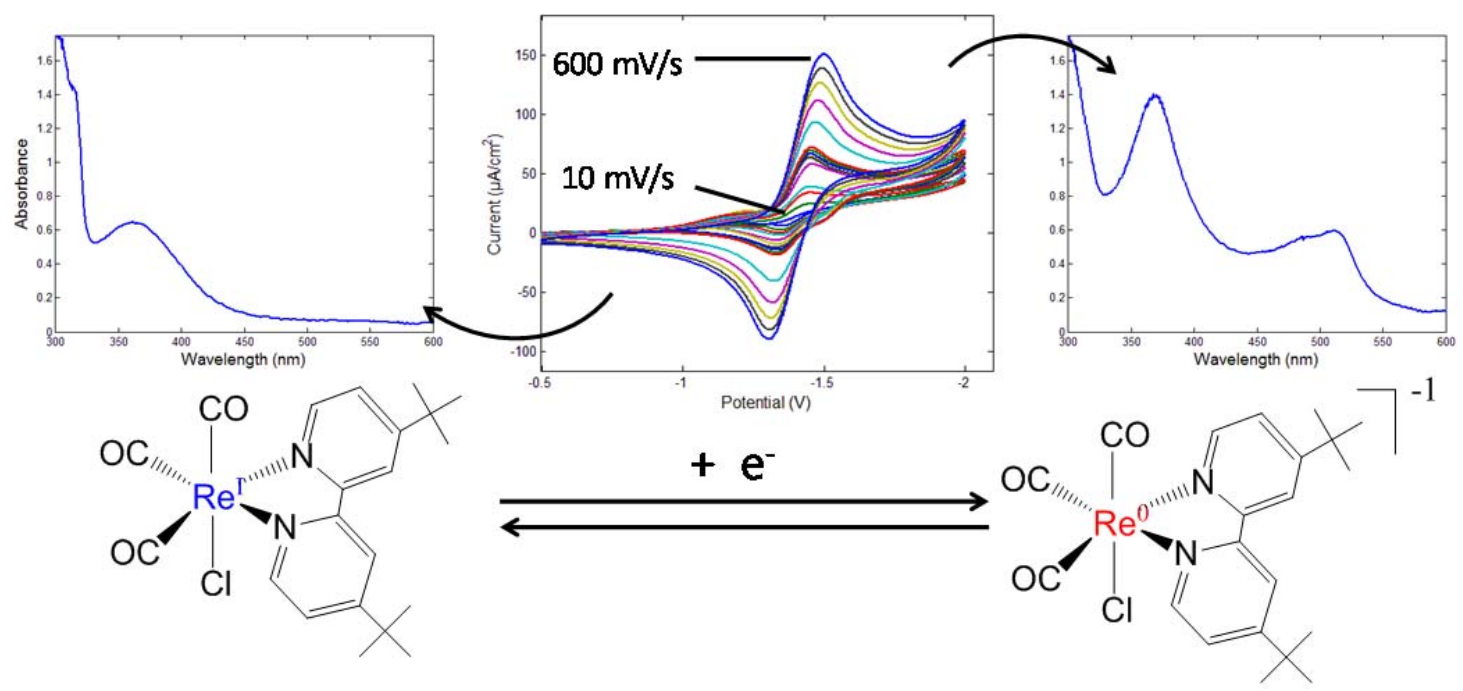

Figure 2.26. Absorbance Spectra Obtained Using $2 \mathrm{mM} \mathrm{Re(dbbpy)(CO)})_{3} \mathrm{Cl}$ and $0.1 \mathrm{M}$ TBACl Solution in Dimethylforamide (DMF)

The absorbance mode spectroelectrochemical measurement of $\mathrm{Re}(\mathrm{dbbpy})(\mathrm{CO})_{3} \mathrm{Cl}$ is shown in Figure 2.27. The potential was modulated as a step function, between -1.0 and $-1.6 \mathrm{~V}$, and held for 5 minutes at each potential. The solution contained $2 \mathrm{mM} \mathrm{Re}(\mathrm{dbbpy})(\mathrm{CO})_{3} \mathrm{Cl}$ using $0.1 \mathrm{M}$ TBACl as the supporting electrolyte in DMF solution. This figure demonstrates the ability to electrochemically modulate the $\operatorname{Re}(\mathrm{I} / 0)$ complex while simultaneously monitoring the optical absorption signal for the reduced and oxidized forms for the $\left[\mathrm{Re}(\mathrm{dbbpy})(\mathrm{CO})_{3} \mathrm{Cl}\right]^{0 / 1-}$ complex.
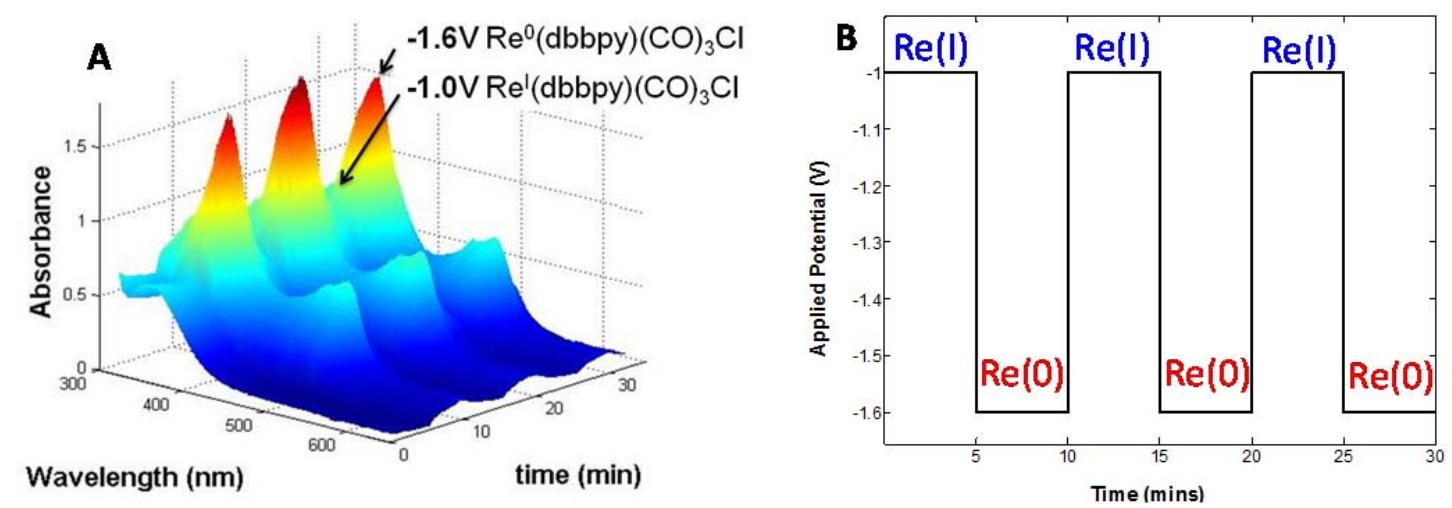

Figure 2.27. Absorbance Modulation for $2 \mathrm{mM} \mathrm{Re}(\mathrm{dbbpy})(\mathrm{CO})_{3} \mathrm{Cl}$ and $0.1 \mathrm{M}$ TBACl Solution in DMF. Potential was modulated between -1.0 and $-1.6 \mathrm{~V}$ and potential was held for 5 minutes.

Emission measurement of $\left[\mathbf{T c}(\mathbf{C O})_{3}(\mathbf{b p y})\left(\mathrm{H}_{2} \mathrm{O}\right)\right]^{+}$. A sample of $\left[\mathrm{Tc}(\mathrm{CO})_{3}(\mathrm{bpy})\left(\mathrm{H}_{2} \mathrm{O}\right)\right]^{+}$prepared as discussed above was placed within a micro-cuvette for cryogenic laser fluorescence spectroscopic 
analysis. Figure 2.28 shows the resulting fluorescence spectra of $\left[\mathrm{Tc}(\mathrm{CO})_{3}(\mathrm{bpy})\left(\mathrm{H}_{2} \mathrm{O}\right)\right]^{+}$as well as the $\left[\mathrm{Tc}(\mathrm{CO})_{3}\left(\mathrm{H}_{2} \mathrm{O}\right)_{3}\right]^{+}$and bpy starting materials.

From this figure, the emission band of the Tc target complex, $\left[\mathrm{Tc}(\mathrm{CO})_{3}(\mathrm{bpy})\left(\mathrm{H}_{2} \mathrm{O}\right)\right]^{+}$, is apparent with an emission maximum of approximately $600 \mathrm{~nm}$ (emission at red wavelength). The solution emission spectra of both $\left[\mathrm{Tc}(\mathrm{CO})_{3}\left(\mathrm{H}_{2} \mathrm{O}\right)\right]^{+}$and bpy starting materials were also measured and are shown in Figure 2.28. The blanks solutions show no observable emission signal above baseline, indicating the observed emissive complex formed within solution is entirely from the combination of both starting materials, strongly indicating that the target complex $\left[\mathrm{Tc}(\mathrm{CO})_{3}(\mathrm{bpy})\left(\mathrm{H}_{2} \mathrm{O}\right)\right]^{+}$is the emissive species in solution.

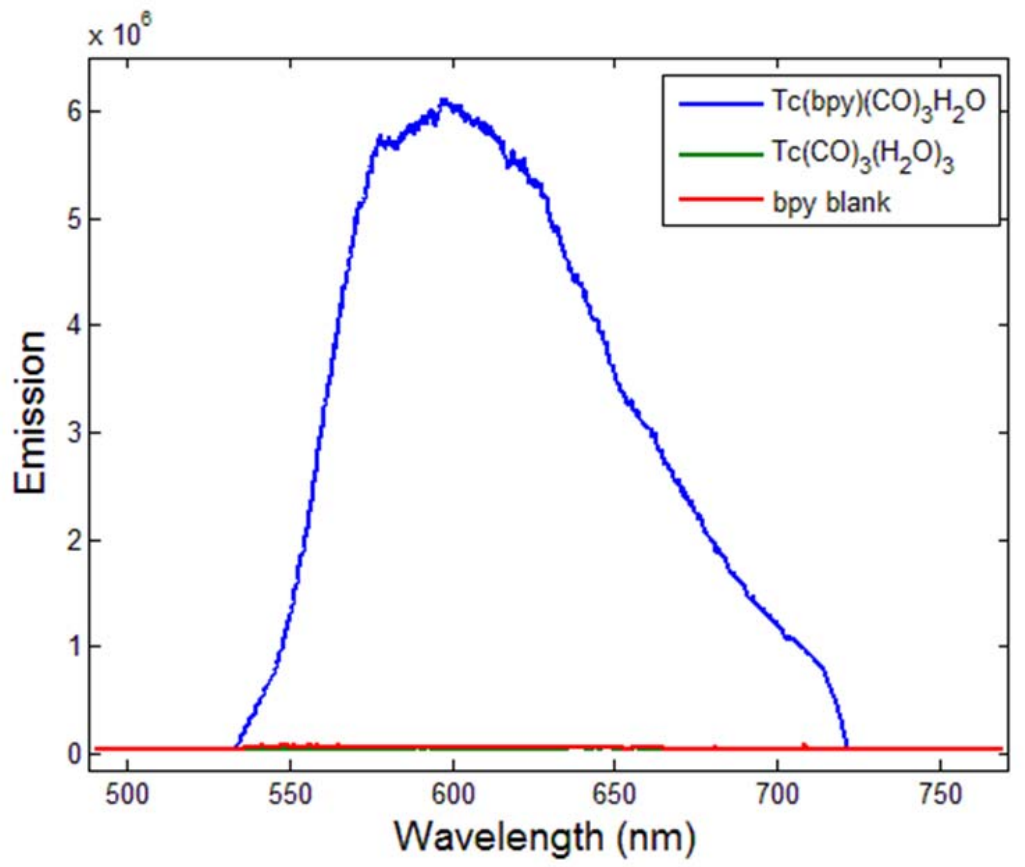

Figure 2.28. Cryogenic Time-Resolved Fluorescence Spectra of $\left[\mathrm{Tc}(\mathrm{CO})_{3}(\mathrm{bpy}) \mathrm{H}_{2} \mathrm{O}\right]^{+}$. Also shown are emission spectra of both $\left[\mathrm{Tc}(\mathrm{CO})_{3}\left(\mathrm{H}_{2} \mathrm{O}\right)_{3}\right]^{+}$and phen starting materials.

Emission measurement of $\left[\mathbf{T c}(\mathbf{C O})_{3}(\text { phen })\left(\mathrm{H}_{2} \mathrm{O}\right)\right]^{+}$. A sample of $\left[\mathrm{Tc}(\mathrm{CO})_{3}(\mathrm{phen})\left(\mathrm{H}_{2} \mathrm{O}\right)\right]^{+}$prepared as discussed above was placed within a micro-cuvette for cryogenic laser fluorescence spectroscopic analysis. Figure 2.29 shows the resulting fluorescence spectra of $\left[\mathrm{Tc}(\mathrm{CO})_{3}(\text { phen })\left(\mathrm{H}_{2} \mathrm{O}\right)\right]^{+}$.

From this figure, the emission band of the Tc target complex, $\left[\mathrm{Tc}(\mathrm{CO})_{3}(\mathrm{phen})\left(\mathrm{H}_{2} \mathrm{O}\right)\right]^{+}$, is apparent. The solution emission spectra of both $\left[\mathrm{Tc}(\mathrm{CO})_{3}\left(\mathrm{H}_{2} \mathrm{O}\right)_{3}\right]^{+}$and phen starting materials were also measured, with the blank solutions containing $\left[\mathrm{Tc}(\mathrm{CO})_{3}\left(\mathrm{H}_{2} \mathrm{O}\right)_{3}\right]^{+}$showing no observable emission above baseline (Figure 2.29A) and the phen blank spectrum showing a moderate signature to lower wavelength than the $\left[\mathrm{Tc}(\mathrm{CO})_{3}(\mathrm{phen})\left(\mathrm{H}_{2} \mathrm{O}\right)\right]^{+}$complex. These results indicate that the observed emissive complex formed within solution is entirely from the combination of both starting materials and strongly suggests that the target complex $\left[\mathrm{Tc}(\mathrm{CO})_{3}(\mathrm{phen})\left(\mathrm{H}_{2} \mathrm{O}\right)\right]^{+}$is the emissive species in solution. Figure $2.29 \mathrm{~B}$ shows the emission spectrum for the $\left[\mathrm{Tc}(\mathrm{CO})_{3}(\mathrm{phen})\left(\mathrm{H}_{2} \mathrm{O}\right)\right]^{+}$complex with the contribution of the phen spectrum subtracted. The emission maximum for the $\left[\mathrm{Tc}(\mathrm{CO})_{3}(\mathrm{phen})\left(\mathrm{H}_{2} \mathrm{O}\right)\right]^{+}$complex is observed at approximately $580 \mathrm{~nm}$ (emission at red-orange wavelength). 

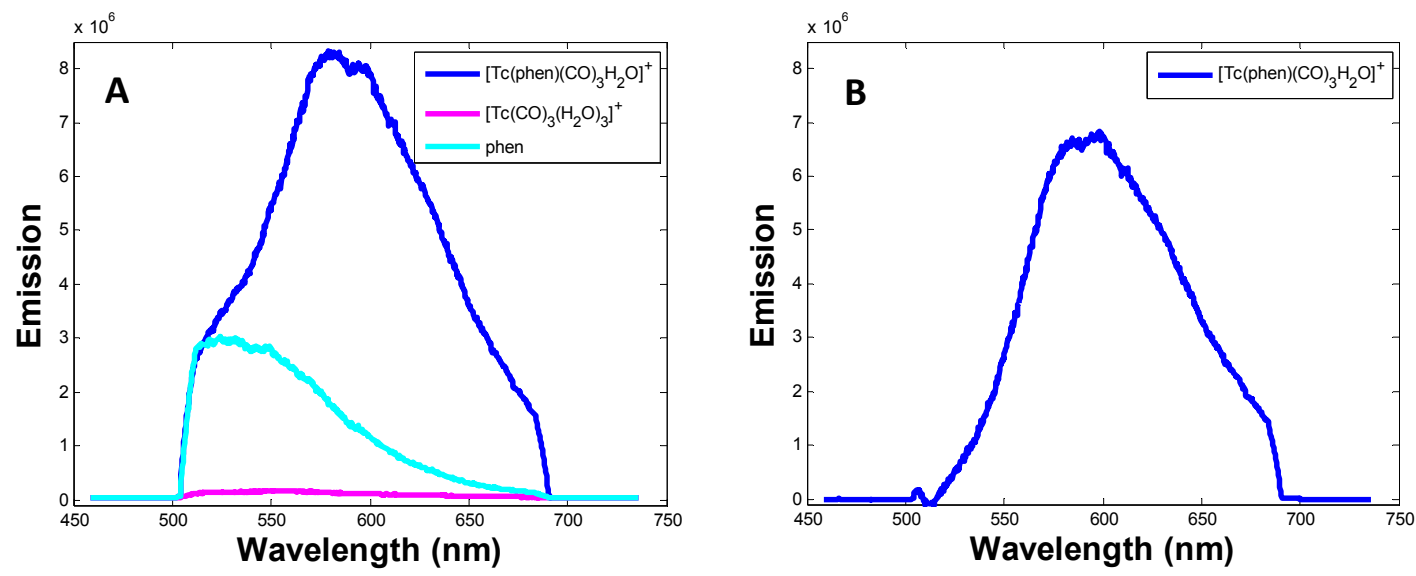

Figure 2.29. (A) Cryogenic Time-Resolved Fluorescence Spectra of $\left[\mathrm{Tc}(\mathrm{CO})_{3}(\mathrm{bpy})\left(\mathrm{H}_{2} \mathrm{O}\right)\right]^{+}$. Also shown are the emission spectra for $\left[\mathrm{Tc}(\mathrm{CO})_{3}\left(\mathrm{H}_{2} \mathrm{O}\right)_{3}\right]^{+}$and phen starting materials. (B) Fluorescence spectra of $\left[\mathrm{Tc}(\mathrm{CO})_{3}(\text { bpy })\left(\mathrm{H}_{2} \mathrm{O}\right)\right]^{+}$After Subtraction of the Fluorescence Signature of Phen Starting Material.

\subsubsection{Summary}

In FY 2013, proof-of-principle work was performed successfully for a spectroelectrochemical film device; this involved preparation of two candidate, low-valent Tc compounds containing this fluorescence-active component and determining the compounds' synthesis, characterization, and spectral properties.

We also have demonstrated the ability to convert the non-emissive $\left[\mathrm{Tc}(\mathrm{CO})_{3}\left(\mathrm{H}_{2} \mathrm{O}\right)_{3}\right]^{+}$or $\left[\mathrm{Tc}(\mathrm{CO})_{3}(\mathrm{X})\left(\mathrm{H}_{2} \mathrm{O}\right)\right]^{+}$complexes into the emissive $\left[\mathrm{Tc}(\mathrm{CO})_{3}(\mathrm{~L} \sim \mathrm{L})\left(\mathrm{H}_{2} \mathrm{O}\right)\right]^{+}$complex $(\mathrm{L} \sim \mathrm{L}=$ bpy or phen), followed by the fluorescence mode detection of these new species in solution. 



\subsection{References}

Alberto R, K Ortner, N Wheatley, R Schibli, and AP Schubiger. 2001. "Synthesis and Properties of Boranocarbonate: A Convenient in Situ Co Source for the Aqueous Preparation of $\left[{ }^{99 \mathrm{~m}} \mathrm{Tc}\left(\mathrm{OH}_{2}\right)_{3}(\mathrm{CO})_{3}\right]^{+}$. "Journal of the American Chemical Society 123(13):3135-36. 10.1021/ja003932b.

Alberto R, R Schibli, R Waibel, U Abram, and AP Schubiger. 1999. "Basic Aqueous Chemistry of $\left[\mathrm{M}\left(\mathrm{OH}_{2}\right)(\mathrm{CO})_{3}\right]^{+}(\mathrm{M}=\mathrm{Re}, \mathrm{Tc})$ Directed Towards Radiopharmaceutical Application." Coordination chemistry reviews 190:901-19.

Alberto R, R Schibli, A Egli, AP Schubiger, U Abram, and TA Kaden. 1998a. "A Novel Organometallic Aqua Complex of Technetium for the Labeling of Biomolecules: Synthesis of $\left.{ }^{99 \mathrm{~m}} \mathrm{Tc}\left(\mathrm{OH}_{2}\right)_{3}(\mathrm{CO})_{3}\right]^{+}$from $\left.{ }^{99 \mathrm{~m}} \mathrm{TcO}_{4}\right]^{-}$in Aqueous Solution and Its Reaction with a Bifunctional Ligand." Journal of the American Chemical Society 120(31):7987-88. 10.1021/ja980745t.

Alberto R, R Schibli and A Egli. 1998b. Method for the Preparation of Facial Metal Tricarbonyl Compounds and Their Use in the Labelling of Biologically Active Substrates. EP 1019095 B1. fsWO $98 / 48848$.

Alberto R, R Schibli, A Egli, U Abram, S Abram, TA Kaden, and AP Schubiger. 1998c. "Steps Towards $\left[\left(\mathrm{C}_{5} \mathrm{Me}_{5}\right) \mathrm{TcO}_{3}\right]$ : Novel Synthesis of $\left[\left(\mathrm{C}_{5} \mathrm{Me}_{5}\right) \mathrm{Tc}(\mathrm{CO})_{3}\right]$ from $\left[\left\{\mathrm{Tc}\left(\mu_{3}-\mathrm{OH}\right)(\mathrm{CO})_{3}\right\}_{4}\right]$ and Oxidation of $\left[\left(\mathrm{C}_{5} \mathrm{Me}_{5}\right) \mathrm{M}(\mathrm{CO})_{3}\right](\mathrm{M}=\mathrm{Tc}, \mathrm{Re})$ with $\mathrm{Br}_{2}$." Polyhedron 17(7):1133-40. http://dx.doi.org/10.1016/S02775387(97)00500-7.

Alberto R, R Schibli, A Engli, AP Schubiger, WG Herrmann, G Artus, U Abram, and TA Kadan. 1995. "Metal carbonyl syntheses XXII. Low pressure carbonylation of $\left[\mathrm{MOCl}_{4}\right]$ " and $\left[\mathrm{MO}_{4}\right]$ ": the technetium(I) and rhenium(I) complexes $\left[\mathrm{NEt}_{4}\right]_{2}\left[\mathrm{MCl}_{3}(\mathrm{CO})_{3}\right]$." Journal of Organometallic Chemistry, 493, 119-127.

Bäckman P, M Bastos, D Hallén, P Lönnbro, and I Wadsö. 1994. "Heat Conduction Calorimeters: Time Constants, Sensitivity and Fast Titration Experiments." Journal of Biochemical and Biophysical Methods 28(2):85-100. http://dx.doi.org/10.1016/0165-022X(94)90023-X.

Brown CF, JH Westsik, Jr., RJ Serne, BM Rapko, WR Wilmarth, DJ McCabe, CA Nash, and AD Cozzi. 2013. Preliminary Assessment of the Low-Temperature Waste Form Technology Coupled with Technetium Removal. Report No. PNNL-22103, Pacific Northwest National Laboratory, Richland, Washington.

Buschmann HJ and E Schollmeyer. 1999. "A Test Reaction from Macrocyclic Chemistry for Calorimetric Titrations." Thermochimica Acta 333(1):49-53. http://dx.doi.org/10.1016/S00406031(99)00096-9.

Chatterjee S, AS Del Negro, MK Edwards, SA Bryan, N Kaval, N Pantelic, LK Morris, WR Heineman, and CJ Seliskar. 2011a. "Luminescence-Based Spectroelectrochemical Sensor for $\left[\mathrm{Tc}(\mathrm{Dmpe})_{3}\right]^{2+/+}$ (Dmpe $=1,2-B i s($ Dimethylphosphino)Ethane) within a Charge-Selective Polymer Film." Analytical Chemistry 83(5):1766-72. 10.1021/ac1030368. 
Chatterjee S, AS Del Negro, Z Wang, MK Edwards, FN Skomurski, SE Hightower, JA Krause, B Twamley, BP Sullivan, C Reber, WR Heineman, CJ Seliskar, and SA Bryan. 2011b. "Electronic and Molecular Structures of Trans-Dioxotechnetium(V) Polypyridyl Complexes in the Solid State." Inorganic Chemistry 50(12):5815-23. 10.1021/ic200747v.

Cho H, WA de Jong, BK McNamara, BM Rapko, and IE Burgeson. 2004. "Temperature and Isotope Substitution Effects on the Structure and NMR Properties of the Pertechnetate Ion in Water." Journal of the American Chemical Society 126(37):11583-88. 10.1021/ja047447i.

DeAngelis TP and WR Heineman. 1976. “An Electrochemical Experiment Using an Optically Transparent Thin Layer Electrode.” Journal of Chemical Education, 53, 594.

Del Negro AS, CJ Seliskar, WR Heineman, SE Hightower, SA Bryan, and BP Sullivan. 2006. "Highly Oxidizing Excited States of Re and Tc Complexes." Journal of the American Chemical Society 128(51):16494-95. 10.1021/ja067114g.

Del Negro AS, Z Wang, CJ Seliskar, WR Heineman, BP Sullivan, SE Hightower, TL Hubler, and SA Bryan. 2005. "Luminescence from the Trans-Dioxotechnetium(V) Chromophore." Journal of the American Chemical Society 127(43):14978-79. 10.1021/ja054906m.

Franklin KJ, CJL Lock, BG Sayer, and GJ Schrobilgen. 1982. "Chemical Applications of Technetium-99 NMR Spectroscopy: Preparation of Novel Technetium(Vii) Species and Their Characterization by Multinuclear NMR Spectroscopy." Journal of the American Chemical Society 104(20):5303-06. 10.1021/ja00384a007.

Gokel GW, DJ Cram, CL Liotta, HP Harris, and FL Cook. 1974. "Preparation and Purification of 18-Crown-6." Journal of Organic Chemistry 39(16):2445-2446.

Gorshkov NI, AA Lumpov, AE Miroslavov, VA Mikhalev, and DN Suglobov. 2003a. "999 Tc NMR Study of Complexation of $\left[\mathrm{Tc}(\mathrm{CO})_{3}\left(\mathrm{H}_{2} \mathrm{O}\right)_{3}\right]^{+}$with Halide and Thiocyanate Ions in Aqueous Solutions." Czechoslovak Journal of Physics 53(1):A745-A49. 10.1007/s10582-003-0096-6.

Gorshkov NI, AE Miroslavov, AA Lumpov, DN Suglobov, and VA Mikhalev. 2003b. "Complexation of Tricarbonyltechnetium(I) Ion with Halide and Thiocyanate Ions in Aqueous Solution: ${ }^{99}$ Tc NMR Study." Radiochemistry 45(2):127-30. 10.1023/A:1023868806380.

Gorshkov NI, AA Lumpov, AE Miroslavov, and DN Suglobov. 2000. Synthesis of $\left[\mathrm{Tc}(\mathrm{CO})_{3}{ }^{+} \cdot\left(\mathrm{H}_{2} \mathrm{O}\right)_{3}\right]^{+}$ ion and investigation of its reaction with hydroxyl ion in the aqueous solutions. Radiochemistry, 45(2):116-119.

Izatt RM, JH Rytting, DP Nelson, BL Haymore, and JJ Christensen. 1969. ”Binding of Alkali Metal Ions by Cyclic Polyethers: Significance in Ion Transport Processes." Science 164:443-444.

Kissinger PT and WR Heineman. 1996. Laboratory Techniques in Electroanalytical Chemistry, 2nd Ed., Dekker, New York, pp 73-76. 
Kurz P, B Probst, B Spingler, and R Alberto. 2006. "Ligand Variations in $\left[\operatorname{Re}_{\mathrm{x}}(\right.$ Diimine $\left.)(\mathrm{CO})_{3}\right]$ Complexes: Effects on Photocatalytic $\mathrm{CO}_{2}$ Reduction." European Journal of Inorganic Chemistry 2006(15):2966-74. 10.1002/ejic.200600166.

Liu Y and JM Sturtevant. 1995. "Significant Discrepancies between Van't Hoff and Calorimetric Enthalpies. Ii." Protein Science 4(12):2559-61. 10.1002/pro.5560041212.

Lukens WW, DK Shuh, NC Schroeder, and KR Ashley. 2004. "Identification of the Non-Pertechnetate Species in Hanford Waste Tanks, Tc(I)-Carbonyl Complexes." Environmental Science \& Technology 38(1):229-33. 10.1021/es034318d.

Mikhalev VA. 2005. "99 Tc NMR Spectroscopy." Radiochemistry 47(4):319-33. 10.1007/s11137-0050097-3.

Miroslavov AE, GB Sidorenko, IV Borisova, EK Legin, AA Lychev, and DN Suglobov. 1990.

"Principal Features of Formation Conditions and Properties of the Lowest Technetium Carbonylhalides." Radiochemistry, 32(6): 573-579.

Mizoue LS and J Tellinghuisen. 2004. “Calorimetric vs. van't Hoff Binding Enthalpies from Isothermal Titration Calorimetry: $\mathrm{Ba}^{2+}$-Crown Ether Complexation." Biophysical Chemistry 110: 15-24.

Park KB, SH Park, HJ Gwon, SJ Choi, BC Shin, YD Hong, SM Choi, WW Park, KH Han, and BS Jang. 2005. Method for the preparation of technetium or rhenium complex for radiopharmaceuticals. US Patent 6936240.

Perrin DD and WLF Armarego. 1988. Purification of Laboratory Chemicals. Pergamon Press, Oxford, England.

Rao L. 2011. "Application of Thermodynamic and Spectroscopic Techniques to the Studies of Actinide Complexation." Progress in Chemistry 23, No.7:1295-1307.

Rapko BM, SA Bryan, JL Bryant, S Chatterjee, MK Edwards, JY Houchin, T Janik, TG Levitskaia, JM Peterson, RA Peterson, SI Sinkov, FN Smith, and R Wittman. 2013. Development of a Chemistry-Based, Predictive Method for Determining the Amount of Non-Pertechnetate Technetium in the Hanford Tanks: FY2012 Progress Report. Report No. PNNL-22173, Pacific Northwest National Laboratory, Richland, WA.

Rard JA. 1983. Critical Review of the Chemistry and Thermodynamics of Technetium and Some of Its Inorganic Compounds and Aqueous Species. Report No. UCRL-53440, Lawrence Livermore National Laboratory, Livermore, California.

Richter MM, JD Debad, DR Striplin, GA Crosby, and AJ Bard. 1996. "Electrogenerated chemiluminescence." Analytical Chemistry 68 (24), 4370-4376.

Smieja JM and CP Kubiak. 2010. "Re(Bipy-Tbu)(CO) $)_{3} \mathrm{Cl}$-Improved Catalytic Activity for Reduction of Carbon Dioxide: Ir-Spectroelectrochemical and Mechanistic Studies." Inorganic Chemistry 49(20):928389. 10.1021/ic1008363. 
Solov'ev VP, NN Strakhova, VP Kazachenko, AF Solotnov, VE Baulin, OA Raevsky, V Rüdiger, F Eblinger, and H-J Schneider. 1998. "Steric and Stereoelectronic Effects in Aza Crown Ether Complexes[1]." European Journal of Organic Chemistry 1998(7):1379-89. 10.1002/(SICI)10990690(199807)1998:7<1379::AID-EJOC1379>3.0.CO;2-9.

Takayama T, A Harano, T Sekine, and H Kudo. 2005. "Phenoxo-Bridged Dimeric Structure of Technetium (I) Tricarbonyl Complex with Schiff Base Ligand." Journal of Nuclear and Radiochemical Sciences 6(3):149-52.

Vogel AI and GH Jeffery. 1989. Vogel's textbook of quantitative chemical analysis. Longman Scientific \& Technical, Wiley, New York, NY.

Wang Z, JM Zachara, PL Gassman, C Liu, O Qafoku, and JG Catalano. "Fluorescence Spectroscopy of U(VI)-Silicate and U(VI)-Contaminated Hanford Sediment.” Geochim. Cosmochim. Acta 2005a, 69 (6), 1391-1403.

Wang ZM, JM Zachara, JP McKinley, and SC Smith. "Cryogenic Laser Induced U(VI) Fluorescence Studies of a U(VI) Substituted Natural Calcite: Implications to U(VI) speciation in contaminated Hanford sediments." Environmental Science \& Technology 2005b, 39 (8), 2651-2659. 
PNNL-22957

EMSP-RPT-018

No. of

Copies

OFFSITE

3 U.S. Department of Energy Office of River Protection

TW Fletcher

BM Mauss

SH Pfaff

4 Washington River Protection Solutions

JB Duncan

RA Robbins

DJ Swanberg

LE Thompson

\section{Distribution*}

No. of

Copies

\section{ONSITE}

10 Pacific Northwest National Laboratory

SA Bryan

JL Bryant

S Chatterjee

MK Edwards

JY Houchin

TG Levitskaia

JM Peterson

RA Peterson

BM Rapko

SI Sinkov

*All distribution will be made electronically. 


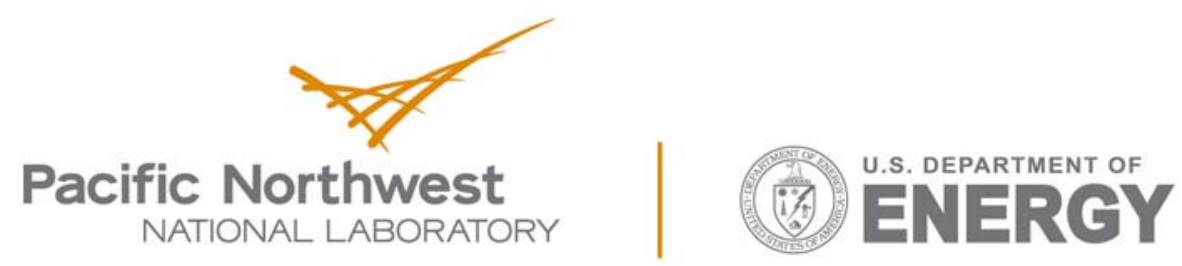

Proudly Operated by Battelle Since 1965

902 Battelle Boulevard

P.O. Box 999

Richland, WA 99352

1-888-375-PNNL (7665)

www.pnnl.gov 